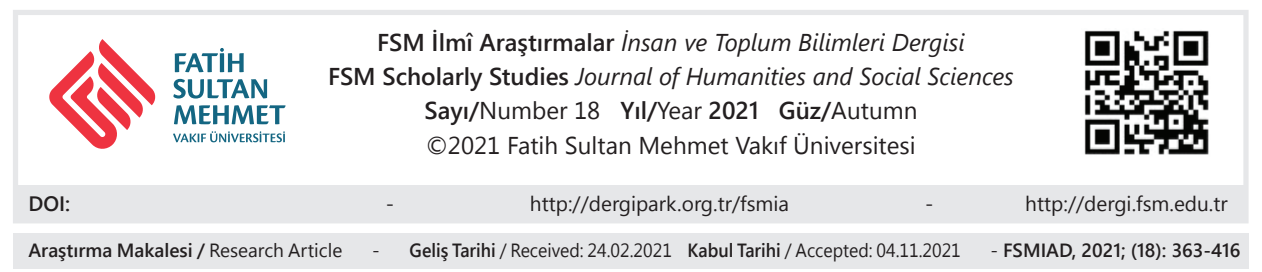

\title{
Tabip bir Osmanlı Müfessiri: Hacı Paşa Aydınî (v. 1424) ve Mecma'u'l-Envâr Adlı Tefsiri
}

Hidayet Aydar

\section{Öz}

$\mathrm{Bu}$ çalışmada ilk dönem Osmanlı âlimlerinden olan Hacı Paşa Aydınî ve Mecma'u'l-envâr fì cemî'i'l-esrâr adlı tefsiri ele alınmaktadır. Çalışmada Hacı Paşa'nın hayat1, eğitim-öğretimi ve tahsil için gittiği merkezler işlenmektedir. Hacı Paşa aslında bir müfessir olmaktan ziyade bir tabip olarak meşhurdur. Çalışmada neden doktor olarak şöhret bulduğu üzerinde de durulmaktadır. Hacı Pasa Aydınî çoğunluğu tabâbetle ilgili olmak üzere çok sayıda eser telif etmiştir. Bunlardan biri de Mecma'u'l-envâr fì cemî'i'l-esrâr adlı tefsiridir. Çalışmada Hacı Paşa Aydınî’nin bir tefsir yazmaya ihtiyaç duymasının sebebi irdelenmektedir. Kütüphanelerimizde çok az sayıda nüshası bulunan tefsir, müellifi tarafından tamamlanmış olduğu halde bugüne kadar biri ilk, diğeri de onuncu cilt olmak üzere sadece iki cildi bilinmekteydi. Ayrıca son cildi bilinmediğinden tamamının kaç cilt olduğu da bilinmiyordu. Araştırmalarımız neticesinde eserin son cildi olan on ikinci cildini de tespit ettik. Böylece eserin toplam on iki cilt olduğu netleşti. Bununla birlikte şimdilik tefsirin geri kalan ciltleri kayıptır. Çalışmada elde mevcut iki nüsha ve yeni tespit ettiğimiz on ikinci cilt hakkında bilgi de verilmektedir. Yine müellifin tefsirindeki yöntemi konusunda da bilgi sunulmaktadır. Eserin kaynakları ve daha önceki tefsirlerle

\footnotetext{
* $\quad$ Prof. Dr., İstanbul Üniversitesi İlahiyat Fakültesi Tefsir Anabilim Dalı, İstanbul/Türkiye, hidayet@istanbul.edu.tr, orcid.org/0000-0002-7563-5073.
} 
münasebeti de ele alınıp işlenmektedir. Bilhassa Ebû Hafs Necmüddîn Ömer en-Nesefî ve Râzî tefsirleriyle sıkı bir ilişkisinin olduğu örnek metinler üzerinden kıyaslar yapılarak tespit edilmeye çalışılmaktadır. Keza eserin mukaddimesinde, ilmin ve âlimin faziletine dair verdiği bilgiler de çalışmada konu edilmektedir.

Anahtar Kelimeler: Osmanlı Müfessiri, Hacı Paşa Aydınî, Mecma'u'l-Envâr fì Cemî'i'l-Esrâr, tefsir, yöntem, mukayese.

\title{
A Physician Ottoman Commentator: Hacı Pasha Aydınî (d. 1424) and his Commentary on Mecma'u'l-Envâr
}

\begin{abstract}
In this study, one of the Ottoman scholars, Haci Pasha Aydin̄̄, and his tafsīr (exegesis) named Majmā al-anwār fì jamī' al-asrār, is discussed. In the study, the life of Haci Pasha, an early Ottoman scholar, and the places he went for education and training are covered. Haci Pasha actually became famous as a doctor rather than a mufassir. The study also emphasizes why he became a doctor and why he gained fame as a doctor. Haci Pasha Aydin̄ wrote many works, mostly in the medical field. One of them is his exegesis named Majmā’ al-anwār fĩ jamī’ al-asrār. Here, the reason why Haci Pasha Aydin̄̄ needed to write an exegesis and which motives led him to write an exegesis are also examined. His exegesis named Majmā' al-anwār fì jam̄̄' al-asrār is a work that has very few copies in our libraries. Although the work was completed by the author, unfortunately, only two volumes, one of which was first and the other was tenth, were known so far. In addition, since the final volume was not known, the total number of volumes was not known. In our studies, we determined the twelfth volume, which is the last volume of the work. Thus, it became clear that the work had a total of twelve volumes. For now, however, most of the exegesis is unfortunately missing. In the study, information about the two existing copies and their location is presented. Especially, the twelfth volume, which we recently identified, is emphasized. Again, in the study, information is given about the author's method in his exegesis and his style of handling various issues. The sources of the work and especially its relationship with previous exegeses are also discussed. It is stated that he had a very close relationship with Abû Hafs Najm al-din Omar el-Nesefî and Rāzì's exegesis in particular. Here, this issue is tried to be determined by making comparisons over the sample texts. The preliminary of the work, some of the issues mentioned here, and especially the information given by him regarding 'ilm (science) and the virtue of the 'âlim (scholar) are also included in the study.
\end{abstract}

Keywords: Ottoman exegesis, Haci Pasha Aydin̄̄, Majmā’ al-Anwār fī Jamī‘ al-Asrār, exegesis, method, comparison. 


\section{Giriş}

Tefsir Tarihine bakıldığında tefsir yazan pek çok şahsın olduğu görülür. Önceleri daha ziyade şifâhî ve nakil yoluyla başlayan tefsir hareketi, hicrî ikinci asırda yazılı tefsirlerin zuhûruyla yeni bir şekil kazanmıştır. Artık tefsirler kalem, kâğıt ve kitap yoluyla oluşturulur ve yayılır olmuştur. Abbasîler devrinde muhtelif bölgelerde çok sayıda tefsir vücuda getirilmiştir. Fatımîler ve Memlûkler dönemlerinde Misır'da, Eyyûbîler devrinde Irak ve Suriye'de, Büveyhîler döneminde İran'da, Selçuklular devrinde Orta Asya ve İran'da, Gazneliler döneminde Hindistan'da birçok müfessir önemli tefsirlere imza atmışlardır. Aynı dönemlerde Endülüs'te de mühim müfessirler yetişmiş ve faydalı tefsirler yapılmıştır. Osmanlı asırlarında da hem Anadolu coğrafyasında, hem de Osmanlının hâkimiyeti altında bulunan diğer bölgelerde tefsir hareketi daha önce de olduğu gibi çeşitlenerek devam etmiştir. Osmanlı' da telif tefsirler yanında tercüme tefsirler de söz konusu olmuştur. Telif tefsirler üzerinde çok sayıda şerh, hâşiye ve talikler yapılmıştır. Tam tefsirler yanında bazı cüzlerin, sûrelerin, âyetlerin, hatta âyet parçalarının dahi tefsirleri yazılmıştır. Arapça tefsirler yanında Farsça, Türkçe ve diğer bazı yerel dillerde de tefsirler vücuda getirilmiştir. Osmanlı'nın kuruluş döneminde başlayan tefsir hareketi, içeride ve dışarıda pek çok savaş yapılmasına rağmen artarak devam etmiştir. Şihâbüddin Sivasî, Kutbuddin İznikî, Molla Gürânî gibi Hacı Paşa Aydınî de Osmanlının ilk dönemlerinde ortaya çıkmış önemli müfessirlerden biridir.

Hacı Paşa Aydınî hakkında yapılan ilk çalışmalar daha ziyade tıp alanındaki eserleriyle ilgilidir. ${ }^{1}$ Tefsiriyle ilgili yapılmış çalışmalara gelince Ziya Demir, XIII-XVI. Yüzyıl Arası Osmanlı Müfessirleri ismiyle basılan Doktora tezinde, Muhammed Abay da Osmanlı Dönemi Müfessirleri ${ }^{3}$ adlı Yüksek Lisans tezinde bu konuda önemli bilgiler vermişlerdir. Demir, sadece mevcut iki cilt hakkında genel bilgilerin yanında, ciltlerin başı, sonu ve feră̆ kaydı hususlarını belirtmiştir. Abay ise eser ve muhtevası hakkında daha fazla bilgi vermiş ve bazı örnekler

1 Bk. Zafer Önler, "Celâleddin Hızır (Hacı Paşa) Müntahab-1 Şifa İnceleme-Metin-Dizinler”, (Yayımlanmamış Doktora Tezi), Fırat Üniversitesi Sosyal Bilimler Enstitüsü Türk Dili ve Edebiyatı Ana Bilim Dalı, Elazığ, 1981; Adnan A. Rıza, "Hacı Paşa'nın Kitab-1 Şifau'l-Eskam ve Devaül-Alam Adlı Eseri Üzerinde İnceleme”, (Yayımlanmamış Yüksek Lisans Tezi), Ankara Üniversitesi Sağlık Bilimleri Enstitüsü, Farmasötik Teknoloji Ana Bilim Dalı, Farmasötik Teknoloji Bilim Dalı, 1987; Zikri Turan, "Hacı Paşa (Celaleddin Hızır) Teshil, Dil Özellikleri Metin (1. Cilt)", (Yayımlanmamış Doktora Tezi), İnönü Üniversitesi Sosyal Bilimler Enstitüsü, Türk Dili ve Edebiyatı Ana Bilim Dalı, 1992.

2 İstanbul, Ensar Neşriyat, 2007.

3 (Yayımlanmamış Yüksek Lisans Tezi, Uludağ Üniversitesi, 1992). 
üzerinden tefsir yöntemini göstermeye çalışmıştır. Ancak her iki araştırmacı da tezlerinin belli bir kısmında eser hakkında bazı malumatlar vermişlerdir. Tefsiriyle ilgili yapılan ilk tez ise Ahmet Babur'a aittir. ${ }^{4}$ Babur, müellif ve eseri hakkında bilgi verdikten sonra Aydınî'nin rivâyet, dirâyet gibi yönlerden nasıl bir yöntem takip ettiğini örnekler üzerinden vermeye çalışmıştır. Tespit edebildiğimiz ikinci ve son tez ise Ahmed Mahmoud Zakaria Tawfik tarafından yapılmıştır. ${ }^{5}$ Tez Hacı Paşa'nın tefsiriyle ilgili bir tahkik çalışmasıdır. Tawfik, tezinde Hacı Paşa ve tefsiri hakkında oldukça kapsamlı bilgi verdiği gibi, eserin birinci cildinin tahkikini de yapmıştır. Ayrıca tefsirin kaynakları üzerinde de durmuş, müellifin yararlandığ tefsirleri tanıtmıştır. Babur ve Tawfik de Demir ve Abay gibi sadece eserin mevcut ilk cildi ile Sebe-Fussilet arasını kapsayan onuncu cildi hakkında bilgiler vermişlerdir. ${ }^{6} \mathrm{Bu}$ araştırmacıların hiçbiri burada sözünü edeceğimiz on ikinci cildinden bahsetmemişlerdir. Ayrıca genel olarak müellifin Râzî gibi bazı müfessirlerden yararlandığını belirtmişlerse de bizim burada yapmaya çalıştığımız gibi birebir kıyaslamalarla bunu göstermemişlerdir. Öte yandan bu konuda en kapsamlı çalışma olan Tawfik' in tezinin Arapça olması da istifade noktasında Arapça bilmeyen okuyucu açısından sıkıntı meydana getirebilmektedir. Bunların dışında Aydınî'nin tefsirciliğiyle ilgili yazılmış bir makale tespit edemedik. Biz burada sözü geçen çalışmalarda yetersiz olduğunu düşündügümüz hususlar üzerinde duracak ve bilhassa on ikinci cilt hakkında bilgiler vererek araştırmacılara tanitmaya çalışacağız.

\section{Hacı Paşa'nın Yaşadığı Dönemlerde Osmanlıda Tefsir ve Bazı Müfessirler}

Müellif Hacı Paşa on dördüncü yüzyılın son yarısı ile on beşinci asrın ilk çeyreğinde yaşamıştır. Bu dönemler, Osmanlı Devleti açısından önemli başarıla-

4 Ahmet Babur, "Hacı Paşa ve Mecma'u'l-Envâr fi Cemî'i'l-Esrâr Adlı Tefsirindeki Metodu", (Yayımlanmamış Yüksek Lisans Tezi), Necmettin Erbakan Üniversitesi Sosyal Bilimler Enstitüsü Temel İslam Bilimleri Ana Bilim Dalı Tefsir Bilim Dalı, 2016.

5 Ahmed Mahmoud Zakarıa Tawfik, "Hâcî Paşa el-Konevî ve Tefsîruhu Mecma'u'l-Envâr fî̀ Cemî'i'l-Esrâr el-Mucelledu'l-Evvel Dirâse ve Tahkîk”, (Yayımlanmamış Doktora Tezi), Necmettin Erbakan Üniversitesi Sosyal Bilimler Enstitüsü Temel İslam Bilimleri Ana Bilim Dalı Tefsir Bilim Dal1, 2020.

6 Ahmet Babur, "Hacı Paşa ve Mecma'u'l-Envâr fi Cemî'i'l-Esrâr Adlı Tefsirindeki Metodu”, s. 32-37; Ahmed Mahmoud Zakaria Tawfik, "Hâcî Paşa el-Konevî ve Tefsîruhu Mecma'u'l-Envâr fî̀ Cemî'i'l-Esrâr el-Mucelledu'l-Evvel Dirâse ve Tahkîk”, s. 93; Muhammed Abay, "Osmanlı Dönemi Müfessirleri”, (Yayımlanmamış Yüksek Lisans Tezi), Uludağ Üniversitesi Sosyal Bilimler Enstitüsü Temel İslam Bilimleri Ana Bilim Dalı Tefsir Bilim Dalı, 1992, s. 18; Ziya Demir, XIII-XVI. Yüzyıl Arası Osmanlı Müfessirleri, İstanbul, Ensar Neşriyat, 2007, s. 116-117. 
rın elde edildiği dönemler ise de 1402 yılında meydana gelen Ankara Savaşında Yıldırım Bayezid (v. 1403) komutasındaki Osmanlı ordusunun, Timur (v. 1405) komutasındaki orduya mağlup olması ve Yıldırım Bayezid'in Timur'a esir düşmesi büyük bir felaket olmuştur. Savaşın ardından Osmanlı Devletinin düzeni bozulmuş, Yıldırım Bayezid'in çocukları arasında taht kavgaları başlamış ve on yıl süren bu iç savaşlarda Osmanlı Devleti çok büyük zorluk ve sıkıntılar yaşamıştır. Çelebi Mehmed'in (v. 1421) iktidarı ele geçirmesiyle yeniden toparlanma yaşanmış, Anadolu ve Rumeli topraklarında pek çok zaferler elde edilmiştir. ${ }^{7}$

Bu dönemde medreselerde eğitim tam anlamıyla düzenli ve disiplinli bir hal almıştır. Gerek Osmanlı topraklarında yetişmiş olan âlimler, gerekse Suriye, Mısır gibi ülkelere gidip oralarda ilim ve irfanını geliştirerek dönenler medreselerde iyi bir eğitim veriyorlard1. ${ }^{8}$ Medreselerde okutulan en önemli derslerden biri Tefsir idi. ${ }^{9}$ Burada alınan eğitim sayesinde bu dönemde aynı zamanda tefsirle de ilgilenen mühim bazı Osmanlı âlimleri yetişmiştir. Kutbuddin el-İznikî (v. 1418), Bedreddin Simâvî (v. 1420), Molla Fenârî (v. 1431), Mehmed Şah Fenârî (v. 1435) bunlardan bazılarıdır. Tefsir tercümesiyle ilgilenen Ahmed-i Dâî (v. 1424), Musa el-İznikî (v. 1435), İbn Arapşah (v. 1450) da bu meyanda zikredilmesi gereken âlimlerden bazılarıdır. Hacı Paşa Aydınî’ den kısa süre sonra yaşamış müfessirler olarak Alauddin Ali Semerkandî (v. 1455) ve Şehabeddin Sivasî’yi (v. 1456) de zikredebiliriz. Bunların her birinin tefsir alanında yazılmış ya tam tefsiri yahut sûre tefsiri mevcuttur. Müellif Hacı Paşa Aydınî de bu âlimlerden biridir. Ancak Hacı Paşa Aydını̂’yi diğerlerinden ayıran özelliği onun aynı zamanda tababetle de ilgilenen iyi bir tabip olmasıdır.

7 Bk. İsmail Hâmî Danişmend, İzahlı Osmanlı Tarihi Kronolojisi, cilt 1, İstanbul, Türkiye Yayınevi, 1971, s. 168183-; Mustafa Cezar, Mufassal Osmanlı Tarihi Resimli-Haritall, Ankara, Türk Tarih Kurumu, 2010, 1: 238-265.

8 Bk. Mehmet İpşirli, “Medrese (Osmanlı Dönemi)”, Türkiye Diyanet Vakfi İslam Ansiklopedisi, İstanbul, Türkiye Diyanet Vakfı Yayınları, 2003, 28: 327-332 (323-340); Yekta Demiralp, "Erken Dönem Osmanlı Medreseleri”, (Yayımlanmamış Doktora Tezi), Ege Üniversitesi Sosyal Bilimler Enstitüsü Arkeoloji ve Sanat Tarihi Ana Bilim Dalı, 1997, s. 1-9; Mefail Hızlı, "Osmanlı Medreselerinde Okutulan Dersler ve Eserler”, Uludağ Üniversitesi İlahiyat Fakültesi Dergisi, cilt 17, say1 1, 2008, s. 25-46.

9 Bk. Mustafa Öztürk, "Klasik ve Modern Dönem Osmanlı Medrese Geleneğinde Tefsir Tedrisatı", Medrese Geleneği ve Modernleşme Sürecinde Medreseler Uluslararası Sempozyum, 5-7 Ekim 2012, Muş, Alparslan Üniversitesi Yayınları, 2013, 2: 259-279; Mehmet Paçacı, "Osmanlı Medreselerinde Tefsir Öğretiminin Yeri ve Tefsirin Çağdaşlıkla Karşılaşması”, Osmanlı Toplumunda Kur'an Kültürü ve Tefsir Çalışmaları, (içinde), ed. Bilal Gökkır v.dğrl., İstanbul, İlim Yayma Vakfı Yayınları, 2011, 1: 63-90. 


\section{Hacı Paşa Aydınî’nin Hayatı}

Hacı Paşa Aydınî’nin, Aydınlı olup Konya'da doğduğu söylendiği gibi, kitaplarında "el-Konevî" nispetini kullanmasından ötürü aslen Konyalı olduğu,

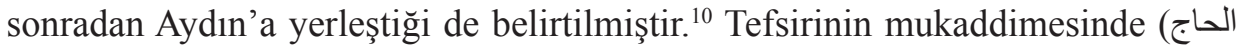
(باثنا بن خو اجه علي بن مراد بن خواجه علي بن حُسام الدين القونوي (şeklinde geçtiği üzere ${ }^{11}$ eserlerinde Konyalı olduğunu sarahaten belirtmesi, Konyalı olduğunu ortaya koymaktadır. Ama daha sonra Aydın'a yerleşmesi, Mısır dönüşü yine burada ikamete devam etmesi, o zamanlar Aydın'a bağlı olan Birgi'de vefat edip defnedilmesi sebebiyle Aydınî diye de meşhur olmuştur. Tarihi tam olarak bilinmemekle birlikte 740/1339 yılından sonra doğduğu tahmin edilmektedir. ${ }^{12}$ Adı Hıdır'dır ancak eserlerinde daha ziyade Hacı Paşa'yı kullanmaktadır. Lakabı da Celaleddin'dir. Buna göre tam adı, Celâleddin Hıdır Hacı Paşa b. Hoca Ali b. Murad b. Hoca Ali b. Hüsameddin el-Konevî el-Aydınî'dir. Babası ve dedesi de hoca olarak geçmektedir. İlimle uğraşan bir ailenin çocuğu olduğu anlaşılmaktadır. Aynı zamanda Anadolu'nun İbn Sînâ'sı olarak da bilinir. ${ }^{13}$ Orhangazi döneminde (1324-1362) dünyaya gelmiş, I. Murat zamanında (1362-1389) Mısır'da eğitim almış, Yıldırım Bayezid döneminde (1389-1403) tanınıp eser yazmaya başlamıştır. Fetret dönemini (1403-1413) yaşamış olan Hacı Paşa, Çelebi Mehmet (Mehmet I) döneminde (1413-1421) bir yandan eserler yazarken, öte yandan da eğitim faaliyetlerinde bulunmuştur. Diğer taraftan tabâbet ilmiyle de ilgilenerek bu konuda dönemin en önemli âlimlerinden biri olmuştur. II. Murad'in (1421-1451) göreve geldiği ilk yıllarda vefat etmiştir. Tefsirini II. Murad döneminde yazmıştır.

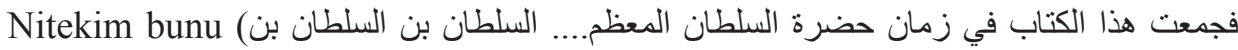

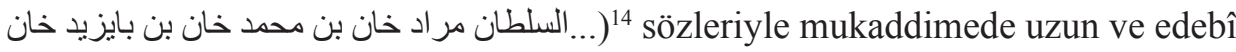

10 Taşköprizâde Ahmed Efendi, eş-Şekâiku'n-Nu'mâniyye fî Ulemâi'd-Devleti'l-Osmâniyye, Beyrût, Dâru'l-Kutubi'l-İlmiyye, ts., s. 34; Bursalı Mehmed Tahir Bey, Osmanlı Müellifleri, haz. İsmail Özen, İstanbul, Meral Yayınevi, 1975, 3: 209; A. Adnan Adıvar, Osmanlı Türklerinde İlim, İstanbul, Remzi Kitabevi, 1982, s. 21-22; Cemil Akpınar, "Hacı Paşa", Türkiye Diyanet Vakfi İslam Ansiklopedisi (DIA), İstanbul, Türkiye Diyanet Vakfı Yayınları, 1996, 14: 493.

11 Başka bazı eserlerinde de bizzat kendisi "Konevî" diyerek Konyalı olduğunu belirtmektedir. (Bk. Ahmet Babur, "Hacı Paşa ve Mecma'u'l-Envâr fi Cemî'i’l-Esrâr Adlı Tefsirindeki Metodu", s. 11).

12 Akpınar, "Hacı Paşa", 14: 492.

13 Mustafa Öztürk, "Osmanlı Tefsir Kültürüne Panoramik Bir Bakış”, Osmanlı Toplumunda Kur'ân Kültürü ve Tefsir Çalışmaları I, (içinde), ed. Bilal Gökkır - Necdet Yılmaz - Necmettin Gökkır - Ömer Kara - Muhammed Abay - Mustafa Karagöz, İstanbul, İlim Yayma Vakfi, 2011, s. 131.

14 Hacı Paşa Aydınî, Mecma 'u'l-Envâr fì Cemî'i'l-Esrâr, Millet Genel Kütüphanesi, Carullah, nr. 94, 1a. 
cümlelerle övüp dualar ettiği sultan II. Murad'ın adını zikrederek belirtmiştir. Dinî ilimler yanında ayrıca tıp alanında da şöhret sahibidir ve bu konuda eserler telif etmiştir.

Memleketinde başladığ 1 eğitimini Anadolu'nun başka merkezlerini gezerek sürdürmüştür. Daha sonra ilim ve kültürünü arttırmak üzere önce Şam'daki Zahiriyye Medresesinde Seyyid Şerif Cürcânî (v. 1413) gibi bazı öğrencilerle birlikte Kutbuddin er-Râzî et-Tahtânî (v. 1365) ve başka hocalardan dersler almıştır. ${ }^{15}$ Daha sonra Misır'a gitmiş, ${ }^{16}$ orada devrin önemli âlimlerinden dersler almıştır. Bilhassa Ekmelüddin Babertî’ den (v. 1384) başta fikıh olmak üzere çok iyi derecede dinî ilimleri öğrenmiştir. Muhammed Mübarek Şah Mantıkî’den (v. 1382?) de aklî ilimleri tahsil etmiştir. ${ }^{17}$

\section{Hacı Paşa Aydınî'nin Tabiplik Yönü}

Hacı Paşa Aydınî, döneminde fazla örnekleri olmayan bir özellik sahibidir; o, tefsir, fıkıh ve hadis âlimi olması yanında ayrıca önemli bir tabiptir. Tıp ilmiyle ilgilenmesi Mısır'da yakalandığı hastalık sebebiyle başlamıştır. ${ }^{18}$ Pençesinde kıvrandığı hastalıktan kurtulmak için çok araştırmalar yapmış, çok kitap okumuştur. Ayrıca bedenle ilgili olması, insanlara büyük hayırlar sağlaması sebebiyle çok önemli bir ilim olduğunu düşündüğü tıp ilmiyle iştigal etmiştir. ${ }^{19}$ Bunun için bölgede bulunan tabiplerden Cemaleddin İbnu'ş-Şevbekî (v. ?) gibi çok kişiyle görüşmeler yaparak onlardan istifade etmiştir. Bu sayede iyi bir tabip olmuştur. $\mathrm{Bu}$ alandaki mahareti ve yeteneği sebebiyle Kahire'de Mansuriye-Kalavun Has-

15 Bk. Akpınar, "Hacı Paşa", 14: 493.

16 Bk. Sara Nur Y1ldiz, "From Cairo to Ayasuluk: Haci Pasa and the Transmission of Islamic Learning to Western Anatolia in the Late Fourteenth Century”, Journal of Islamic Studies, 25/3, 2014, s. 265-270.

17 Bursalı, Osmanlı Müellifleri, 3: 209; Ahmet Faruk Güney, “Gaza Devrinde Kur'ân’1 Yorumlamak: Fetih Öncesi Osmanlı Müfessirleri ve Tefsirleri”, Dîvân İlmî Araştırmalar, sayı 18, 2005/1, s. 220-221.

18 Taşköprülüzâde Ahmed Efendi, Osmanlı Bilginleri eş-Şekâiku'n-Nu'mâniyye fî Ulemâi'd-Devleti'l-Osmâniyye, trc. Muharrem Tan, İstanbul, İz Yayıncılık, 2007, s. 66; Ahmet Süheyl Ünver, Hekim Konyalı Hacı Paşa, İstanbul, stanbul Üniversitesi, 1953, s. 4; Demir, XIII-XVI. Yüzyıl Arası Osmanlı Müfessirleri, s. 114-115; Akpınar, "Hacı Paşa", 14: 493.

19 Nitekim Şifâu'l-Eskâm adlı eserinde bunu açıklamaktadır. Bk. Babur, Hacı Paşa ve Mecma'u'l-Envâr fi Cemî'i'l-Esrâr Adlı Tefsirindeki Metodu, s. 15-16; Y1ldız, "From Cairo to Ayasuluk: Haci Pasa and the Transmission of Islamic Learning to Western Anatolia in the Late Fourteenth Century", s. 273-277. 
tanesine başhekim olarak atanmış ${ }^{20}$ ve burada uzun süre görev yapmıştır. ${ }^{21} \mathrm{Bu}$ arada ilaçlar ve hastalıklar üzerine daha fazla çalışmalar yapma imkânı bulmuştur. ${ }^{22}$ Hacı Paşa Aydınî, Aydın'a döndüğünde ${ }^{23}$ iyi bir âlim olmanın yanında aynı zamanda çok iyi bir tabip idi. Bu sayede Aydınoğlu İsa Bey’in ${ }^{24}$ takdir ve teveccühüne mazhar olmuştur. ${ }^{25}$

Hacı Paşa, muhtemelen tıp ilmini tahsil etmesinde rolü bulunan ${ }^{26}$ İsa Bey için, Şifâu'l-eskâm ve devâu'l-a 'lâm adında bir kitap yazmıştır. ${ }^{27}$ Hacı Paşa daha sonra bu eserini Türkçe olarak Teshîlu't-tıb adıyla muhtasar bir kitap halinde telif etmiştir. ${ }^{28} \mathrm{Bu}$ eser, Türkçe yazılmış ilk tıp kitabıdır. ${ }^{29}$ Arapça olan Şifâu' 'l-eskâm, alanın uzmanları için yazılmış ilmî bir kitap iken, Teshîl, halkın anlayacağı şekilde basit ve anlaş1lır bir dil ile kaleme alınmış, herkesin rahat anlayacağı bir kitap olarak düzenlenmiştir. Hacı Paşa ayrıca Müntehabü'ş-şifa adında bir eser daha yazmıştır ki, bu da Şifâu 'l-eskâm'ın Arapça bir muhtasarıdır ve bu da İsa Bey’e takdim edilmiştir. ${ }^{30}$

Kaynakların verdiği bilgiye göre Yıldırım Bayezid'i yenip Anadolu'ya hâkim olan Timur'un doktorlarıyla tababet alanıyla ilgili bazı görüşmeler yapmış, fikir alışverişinde bulunmuştur. Bu görüşmeler esnasında Timur'un doktorları, onun tababetteki maharet ve ehliyetine, dirâyet ve iradesine hayran kalıp takdir etmişlerdir.

20 Ünver, Hekim Konyalı Hacı Paşa, s. 4; Adıvar, Osmanlı Türklerinde İlim, s. 22.

21 Taşköprizâde, eş-Şekâiku'n-Nu'mâniyye fì Ulemâi'd-Devleti'l-Osmâniyye, s. 34; Edirneli Mecdî Efendî, Şekâik-i Nu'mâniye Tercemesi, İstanbul, Tabhane-i Amire, 1369, s. 74; Bursalı, Osmanlı Müellifleri, 3: 209; Akpınar, "Hacı Paşa", 14: 493.

22 Ersin Kahya, "Konyalı Bir Hekim, Hacı Paşa", Türk-İslam Medeniyeti Akademik Araştırmalar Dergisi (Konya Özel Sayısl), say1 5, 2008, s. 37-46.

23 Yildız, "From Cairo to Ayasuluk: Haci Pasa and the Transmission of Islamic Learning to Western Anatolia in the Late Fourteenth Century", s. 270-272.

24 Bk. Fatma Şentürk, "Aydınoğulları Beyliğinde Edebî ve Kültürel Hayat”, (Yayımlanmamış Yüksek Lisans Tezi), Osmangazi Üniversitesi Sosyal Bilimler Enstitüsü Türk Dili ve Edebiyat1 Ana Bilim Dalı Eski Türk Edebiyatı Bilim Dalı, 2014, s. 7-9.

25 Akpınar, "Hacı Paşa", 14: 493.

26 Akpınar, "Hacı Paşa", 14: 493.

27 Taşköprizâde, eş-Şekâiku'n-Nu'mâniyye fì Ulemâi'd-Devleti'l-Osmâniyye, s. 34; Edirneli Mecdî Efendî, Şekâik-i Nu'mâniye Tercemesi, s. 74; Akpınar, "Hacı Paşa", 14: 493.

28 Taşköprizâde, eş-Şekâiku'n-Nu'mâniyye fì Ulemâi'd-Devleti'l-Osmâniyye, s. 34; Edirneli Mecdî Efendî, Şekâik-i Nu'mâniye Tercemesi, s. 74.

29 Akpınar, "Hacı Paşa", 14: 493.

30 Edirneli Mecdî Efendî, Şekâik-i Nu'mâniye Tercemesi, s. 74. 
Aydınoğlu İsa Bey tarafından Ayasulug (Selçuk) kadılığına atanan Hacı Paşa, aynı zamanda hem Ayasulug'ta hem de Birgi'de bulunan medreselerde ${ }^{31}$ tedris faaliyetlerinde bulunmuş ve birçok öğrenci yetiştirmiştir. ${ }^{32}$ Bunların yanında sarayda hekimlik görevi de yapmıştır. ${ }^{33}$ Hacı Paşa unvanı da burada Aydınoğlu İsa Bey tarafından kendisine verilmiş, o da bundan sonra hep bu lakabı kullanmıştır. ${ }^{34}$

Müellif, Beyzâvî'nin, Tavâli'u'l-envâr adlı eserine bir şerh yazmıştır. ${ }^{35}$ Kutbuddin Râzî'nin Şerhu metali' adlı eserine de Seyyid Şerif Cürcânî'den (v. 816/1413) önce o haşiye yazmıştır. ${ }^{36}$

Ömrünün sonlarına doğru yerleştiği Birgi’de 827/1424 tarihinde vefat etmiş, Hıdırlık Kabristanı yakınına defnedilmiştir. ${ }^{37}$ Müellifin vefat tarihi hakkında başka tarihler de zikredilmiştir, ${ }^{38}$ ancak eserlerinde zikrettiği tarihlere ve Birgi'de geçirdiği yıllara muvafik olması hasebiyle burada verdiğimiz tarih, daha çok tercih edilmiştir. Türbesi hâlen Birgi'de bulunmaktadır. 1935 yılında mezarının üstüne mermerden bir abide yapılmıştır. ${ }^{39}$

\section{Hacı Paşa Aydınî'nin Eserleri}

Hacı Paşa Aydınî'nin muhtelif eserleri bulunmaktadır. ${ }^{40}$ Bunların bir kısmı tıpla ilgilidir. Bundan başka kelam, mantık gibi alanlarda da eserleri mevcuttur. Yukarıda ismi geçen Müntehâb-ı şifâ, Kitâbu't-ta'lîm ve et-Teshîl adlı kitapları hariç diğer eserleri Arapçadır. Meşhur kitapları şunlardır:

31 Bunlar için bk. Şentürk, “Aydınoğulları Beyliğinde Edebî ve Kültürel Hayat”, s. 20-23.

32 Babur, Hacı Paşa ve Mecma'u'l-Envâr fi Cemî'i'l-Esrâr Adlı Tefsirindeki Metodu, s. 19-23.

33 Akpınar, "Hacı Paşa”, 14: 493.

34 Akpınar, "Hacı Paşa”, 14: 493.

35 Bk. Y1ldiz, "From Cairo to Ayasuluk: Haci Pasa and the Transmission of Islamic Learning to Western Anatolia in the Late Fourteenth Century", s. 278-287.

36 Taşköprizâde, eş-Şekâiku'n-Nu'mâniyye fí Ulemâi'd-Devleti'l-Osmâniyye, 34; Edirneli Mecdî Efendî, Şekâik-i Nu'mâniye Tercemesi, 74.

37 Bursalı, Osmanlı Müellifleri, 3: 209-210; Şentürk, “Aydınoğulları Beyliğinde Edebî ve Kültürel Hayat”, s. 30-32; Çağatay Üstün, "Hekim Haci Pasa's (Physician Hadji Pasha) Brief Bioraphy and his Opinions on Medical Deontology", S.D. Ü. Tip Fakültesi Dergisi, cilt 17, say1 1, 2010, s. 29-30.

38 Babur, Hacı Paşa ve Mecma'u'l-Envâr fi Cemî'i'l-Esrâr Adlı Tefsirindeki Metodu, s. 23; Şentürk, "Aydınoğulları Beyliğinde Edebî ve Kültürel Hayat”, s. 33-36.

39 Akpınar, "Hacı Paşa”, 14: 493; Abay, "Osmanlı Dönemi Müfessirleri”, s. 16.

40 Bk. Demir, XIII-XVI. Yüzyıl Arası Osmanlı Müfessirleri, s. 115; Abay, “Osmanlı Dönemi Müfessirleri”, s. 16; Babur, Hacı Paşa ve Mecma'u'l-Envâr fi Cemî'i’l-Esrâr Adlı Tefsirindeki Metodu, s. 32-37. 
(1) Kitâbu 't-ta'lîm (teâlîm) fi ilmi 't-tıb. Adnan Adıvar, Hacı Paşa'nın burada sözünü ettiğimiz et-Ta'lim ve aşağıda gelecek olan eş-Şifâ adlı eserlerinin "asıl”" olduğunu ve bunların diğer bütün eserleri için esas teşkil ettiğini, diğer eserlerinin bunlardan ufak tefek düzeltme ve katmalarla meydana getirildiğini zikretmektedir. ${ }^{41}$

(2) el-Ferîde fí zikri'l-ăgziyeti 'l-müfìde. ${ }^{42}$

(3) Şifâu'l-eskâm ve devâu'l-âlâm (eser Şifây-ı Hacı Paşa, Kanun-i Hacı Paşa diye de bilinmektedir), ${ }^{43}$

(4) el-Usûlu'l-hamse, ${ }^{44}$

(5) Kitâbu's-saâde ve'l-ikbâl murattabun ala erbaati'l-akvâl (el-Kümmiyyu'l-celâlî ve künnâşetu'l-celâl), ${ }^{45}$

(6) Müntehab-ı şifâ: Aynı zamanda Şifây-ı müntehab ${ }^{46}$ diye de bilinir.

(7) et-Teshîl; ${ }^{47}$

(8) Şerhu levâmi'i'l-esrâr fi şerhi matâli'i'l-envâr, ${ }^{48}$

41 Adıvar, Osmanlı Türklerinde İlim, s. 24.

42 Bursalı, Osmanlı Müellifleri, 3: 210; Akpınar, "Hacı Paşa”, 14:494.

43 Bk. Adıvar, Osmanlı Türklerinde İlim, s. 22-23; Akpınar, "Hacı Paşa", 14: 494-495. Sevgi Şar - Bilge Sözen Şabne - Miray Arslan, "Hacı Paşa’nın Şifâü'l-Eskâm ve Devâü'l-Âlâm Adlı Eserindeki Şurup Formülleri”, Ankara Üniversitesi Osmanlı Araştırmaları Merkezi (OTAM), sayı 35, 2014, s. 124-125 (121-136); Berrin Okka, “Tıp Tarihinde Mumyalama İşlemi, Konyalı Hekim Hacı Paşa ve Tahnit”, Uluslararası İslam Medeniyetinde Zaman Sempozyumu, ed. Bilal Kuşpınar, 08-11 Ekim 2015/Konya, İstanbul, Bilir Matbaacılık, 2016, 2: 75-87.

44 Akpınar, "Hacı Paşa", 14:495.

45 Bursalı, Osmanlı Müellifleri, 3: 210-211; Adıvar, Osmanlı Türklerinde Illim, s. 23-24; Akpınar, "Hacı Paşa", 14:495.

46 Bunlar için bk. Bursalı, Osmanlı Müellifleri, 3: 210; Esin Kahya, "Hac1 Paşa”, Ankara Üniversitesi Osmanlı Araştırmaları Merkezi (OTAM), sayı 3, 1992, s. 491 (401-492); Zafer Önler, "Eski Anadolu Türkçesi Döneminde Yazılmış İki Tıp Kitabında Yer Alan Sağlık Bilgisi Terimleri”, Türk Dil Araşstırmaları Yılliğı (TDAY) Belleten, cilt 33, 1985, s. 89 (89-130); a.mlf., "Celâleddin Hızır (Hacı Paşa) Müntahab-ı Şifa Inceleme-Metin-Dizinler”, (Yayımlanmamış Doktora Tezi), Fırat Üniversitesi Sosyal Bilimler Enstitüsü Türk Dili ve Edebiyatı Ana Bilim Dalı, Elazığ, 1981, s. 15-18; Hacı Paşa (Aydınî), Celâl Hızır, Müntahab-ı Şifâ, haz. Zafer Önler, Ankara, Türk Dil Kurumu Yayınları 1990; a.mlf., "XIV-XV. Yüzyıl Türkçe Tıp Metinlerinin Dili ve Sözvarlığı”, Kebikeç, sayı 6, 1998, s. 159.

47 Bursalı, Osmanlı Müellifleri, 3: 210; Adıvar, Osmanlı Türklerinde İlim, s. 24; Akpınar, "Hacı Paşa”, 14: 496; Ahmet Acıduman - Öner İlgili, "Erken dönem Türkçe Tıp Yazmalarından Hacı Paşa'nın (Celalüddin Hızır) Teshîl Adlı Eserinde Çocuk Sağlı̆̆ı ve Hastalıkları Üzerine Bir Ön Çalışma”, Çocuk Sağlığı ve Hastalıkları Dergisi, cilt 54, sayı 4, 2011, s. 233-242 (231-243).

48 Bursalı, Osmanlı Müellifleri, 3: 210; Akpınar, "Hacı Paşa”, 14: 496. 


\section{(9) Şerhu tavâli'i'l-envâr fì ilmi 'l-Kelâm.49}

Basur hastalığına dair Risâle-i bevâsîr ${ }^{50}$ ve insan organlarının seğirmelerinden çıkarılan tıbbî manalarla ilgili İhtilâcnâme adlı Türkçe iki eser de Hacı Paşa'ya isnad edilmiştir. ${ }^{51}$ Ancak bu iki eserin Hacı Paşa'ya ait olduğunu gösteren kesin kanit yoktur. $^{52}$

(10) Kitabu de'bi s-sâlihîn adlı Arapça eser, kitapları arasında geçmiyorsa da ona aidiyeti kuvvetlidir. Zira bu eser, Hacı Paşa'nın şeriat, tarikat, hakikat ve marifet makamları hakkında söylediği bir sözün izahı mahiyetindedir. Öğrencilerinden biri tarafından, bir itiraza cevap sadedinde hazırlanmıştır. Bir nüshası Hacı Selim Ağa Kütüphanesinde bulunmaktadır. ${ }^{53}$

Müellif bu şekilde bilhassa tıp alanıyla ilgili muhtelif eserler kaleme aldığ 1 gibi ayrıca bir de tefsir eseri yazmıştır. Tefsiri

(11) Mecma 'u'l-envâr fî cemî'i'l-esrâr adını taşımaktadır.

Biz burada müellifin tefsiri üzerinde daha fazla durmayı münasip gördüğümüz için diğer eserleri hakkında detaylı bilgi vermeyi, bulundukları kütüphanalere işaret etmeyi gerekli görmedik.

\section{Hacı Paşa Aydınî'ni Mecma'u'l-envâr fî cemî'i’l-esrâr Adı Tefsiri}

Hacı Paşa'nın bu eseri oldukça hacimli bir Kur'ân tefsiridir. ${ }^{54}$ Eser, Hacı Paşa'nın en büyük ve en kapsamlı eseridir. ${ }^{55}$ Katip Çelebi eserin tamamını göremediği için, ondan çok ciltli bir tefsir diye söz etmektedir. ${ }^{56}$ Eserin kaç cilt olduğu tam olarak bilinemiyordu, ancak tespitlerimize göre 1924'lü yıllarda Kastamonu'da bulunan ve Milli Eğitim Bakanlığı Kastamonu Kitaplığı adıyla, bugün ise Yazma Eserler Kurumu Başkanlığına bağlı Kastamonu Yazma Eser Kütüphanesi olarak bilinen kütüphanede (kayıt no: 3065) eserin Mücâdele sûresiyle başlayıp Nas sûresiyle biten bir cildi mevcuttur ve üzerinde on ikinci cilt diye yazılıdır. $\mathrm{Bu}$ sayede artık eserin on iki cilt olduğu kesinleşmiştir.

49 Bk. Bursalı, Osmanlı Müellifleri, 3: 210; Akpınar, "Hacı Paşa”, 14: 496.

50 Ünver, Hekim Konyalı Hacı Paşa, s. 37.

51 Ünver, Hekim Konyalı Hacı Paşa, s. 37.

52 Ünver, Hekim Konyalı Hacı Paşa, s. 37.

53 Akpınar, "Hacı Paşa", 14: 496.

54 Bursal1, Osmanlı Müellifleri, 3: 210.

55 Güney, “Gaza Devrinde Kur'ân'1 Yorumlamak: Fetih Öncesi Osmanlı Müfessirleri ve Tefsirleri”, s. 221.

56 Mustafa b. Abdullah Hacı Halife Kâtip Çelebî, Keşfu'z-zunûn an esâmi'l-kutubi ve'l-fünûn, Beyrût, Dâru İhyâi't-Turâsi'l-Arabî, ts., 2: 1598-1599. 


\subsection{Mevcut Ciltlerin Tanıtımı}

Ziya Demir'in vediği bilgiye göre eserin kütüphanelerimizde tespit edilen iki cildi vardır. Haklarında aşağıda geleceği üzere bilgi verildiği için bu iki cilde kısaca temas edeceğiz.

\subsubsection{Birinci Cildin Tanıtımı}

Bunlardan biri Süleymaniye Kütüphanesi Carullah 94'te bulunan cilttir. Tarafımızdan incelenen nüsha eserin ilk cildini oluşturmaktadır. Kur'ân'ın başından başlayıp Âl-i İmrân sûresi doksan birinci âyetin tefsiriyle son bulmaktadır. Kapağı deri ciltlidir, 250X175, 190X120 mm. ebatındadır, yıpranmış ve miklebi kopmuştur. Kapak koyu kahve rengindedir. Eser iki yüz on sekiz varaktan ibarettir, yaprakları orta kalınlıktadır, yer yer güve sebebiyle tahribat söz konusudur, sayfalar oksitlenmiş aharlı, nohudî renkli filigransızdır. Sayfalarda cetvel yoktur, kenarlar boştur, her sayfada yirmi beş satır bulunmaktadır. Yazının türü rahat okunabilen nesihtir, ince bir uç ve siyah mürekkeple yazılmıştır, durak işaretleriyle âyetlerde kırmızı mürekkep kullanılmıştır. Eserin fihristi ve serlevhası yoktur. ${ }^{57}$

\subsubsection{Onuncu Cildin Tanıtımı}

Diğer bir cilt İstanbul Üniversitesi Kütüphanesi AY 1794 numaradadır ve tarafımızdan kontrol edilmiştir. Eserin onuncu cildini oluşturmaktadır. Sebe sûresinin başından başlayıp Fussilet sûresinin sonuyla bitmektedir. ${ }^{58}$ Cildin sırtı deridir, mikleb ve kapakları ebru kaplı mukavva cilde sahiptir. Kapak 265X190, 195X120 mm. ebatındadır. Varaklar orta kalınlıktadır, sağlam, nohudî renklidir, aharlı ve filigransızdır. Sayfalar cetvelsizdir, cildin serlevhası yoktur, kenarlarında bazı notlar bulunmaktadır. Yazı talik kırmasıdır, kalınca bir uçla siyah mürekkeple yazılmıştır, âyetler ise kırmızı mürekkeple kaleme alınmıştır. Tafsilat verilmek istenen kısımlar kırmızı çizgilerle belirlenmiştir. Eserin ferağ kaydı yoktur. ${ }^{59}$ Araştırmacılar hep bu iki ciltten söz edip haklarında bilgi vermişlerdir.

\subsubsection{On ikinci Cildin Tanıtımı}

Son olarak Milli Eğitim Bakanlığı Kastamonu Kitaplığında (Yazma Eserler Kurumu Başkanlığı Kastamonu Yazma Eser Kütüphanesinde) eserin on iki cildini tespit ettik. Cilt Mücâdele sûresinin başından başlayıp Nas sûresiyle bitmektedir ve eserin son cildini oluşturmaktadır. Cildin sırtı deridir, miklebli-

57 Demir, XIII-XVI. Yüzyıl Arası Osmanlı Müfessirleri, s. 116.

58 Demir, XIII-XVI. Yüzyıl Arası Osmanlı Müfessirleri, s. 117; Akpınar, "Hacı Paşa”, 14: 495496; Abay, "Osmanlı Dönemi Müfessirleri”, s. 26.

59 Demir, XIII-XVI. Yüzyıl Arası Osmanlı Müfessirleri, s. 117. 
dir ve ebru kaplı mukavva cilde sahiptir. Eser numaralandırılmamıştır, yalnız ferağ kaydının olduğu sayfada iki yüz yetmiş beş rakamı vardır. Eser ilk kapağından son kapağına kadar toplam iki yüz doksan beş varaktır. Arada cenaze namazı duası ve niyetini ihtiva eden bazı ilave sayfalar da vardır. Yaprakları orta kalınlıktadır, sayfalar nohudî renkli filigransızdır. Sayfalarda cetvel yoktur, kenarlar boştur, sadece bazı sayfalarda zaman zaman bir takım notlar vardır. Her sayfada yirmi beş satır bulunmaktadır. Yazının türü talik veya bunun küçük harflerle yazılmış okunaklı hali olan nestalik/kırma nestaliktir. Yazı rahat okunabilen, ince bir uç ve siyah mürekkeple yazılmıştır, durak işaretleriyle âyetlerde kırmızı mürekkep kullanılmıştır. Metin içinde âyetlerin üstü kırmızı mürekkeple çizilmiştir. Eserin fihristi ve serlevhası yoktur. Ferağ kaydının altında bazı rübâiler yazılmış, son sayfada ise yazının türünden ve mürekkepten anlaşıldığı kadarıyla eseri istinsah edenden farklı biri tarafından daha sonraki tarihlerde bazı notlar yazılmış, hatta vefk ${ }^{60}$ tarzında bir takım işaretler dahi konulmuştur.

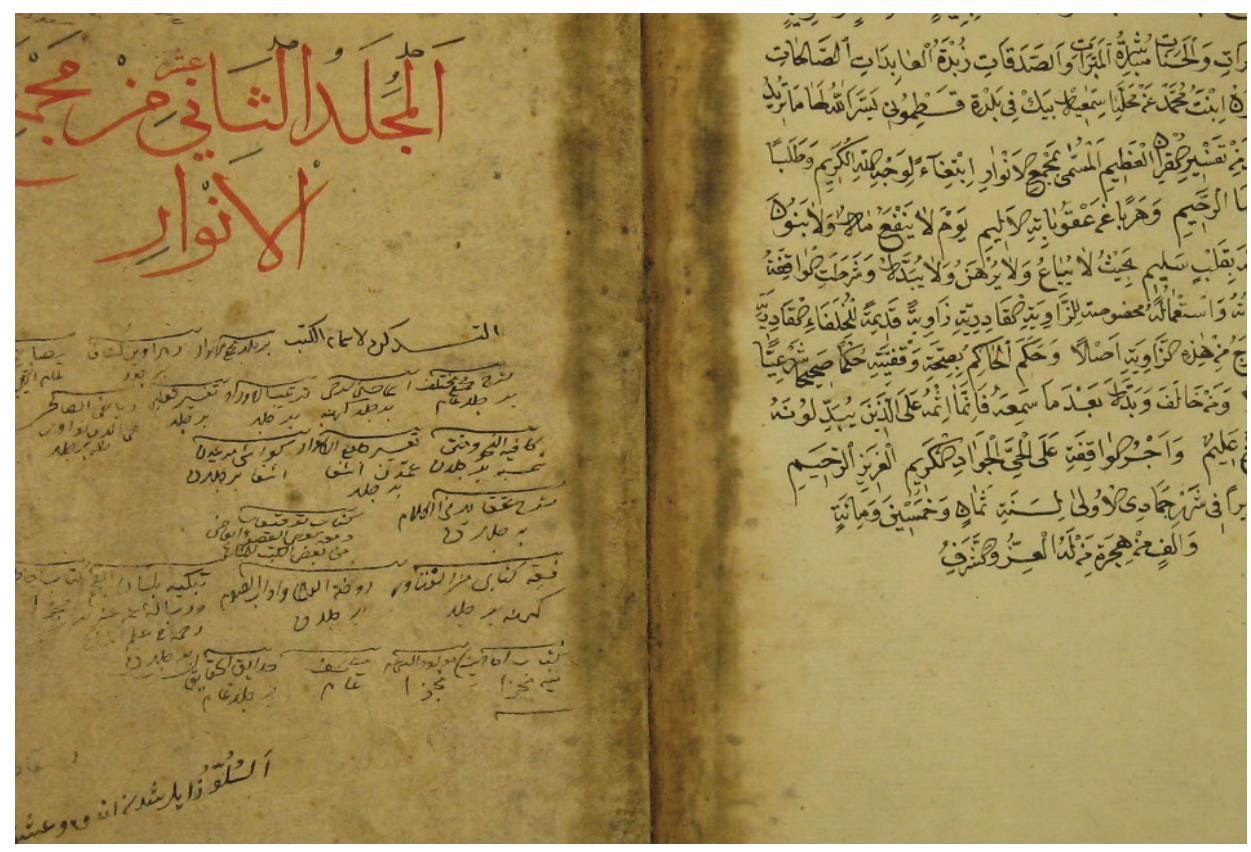

Resim 1. Hacı Paşa Aydın̂̂'nin Mecma'u'l-envâr adlı tefsirinin on ikinci cildi

60 Bk. İlyas Çelebi, "Vefk”, Türkiye Diyanet Vakfi İslam Ansiklopedisi, İstanbul, Türkiye Diyanet Vakfi Yayınları, 2012, 42: 605-607. 
Eser Kastamonu'da İsmail Bey mahallesinde yaşayan Muhammed kızı Ayşe Hatun adında bir kadın tarafından bağışlanmıştır. Ayşe Hanım eseri, satılmaması, rehin alınmaması, değiştirilmemesi kaydıyla bölgede Kâdirî halifeleri için yapılmış eski bir Kâdirî zâviyesine, orada okunmak ve kullanılmak ve asla oradan çıkarılmamak üzere bağışlamıştır. Vakfiyesinin şer'î kurallara göre yapılmış sahih bir vakıf olduğu bölgenin hâkimi tarafindan tescîl edilmiştir. Yine vakfiyenin dua/beddua kısmı olan yerde, eserin ebedî olarak böyle kalması gerektiği, bu vakfa herhangi bir şekilde müdahale edip değiştirenlerin Allah katında mesûl ve günahkâr olacakları belirtilmiştir. Vakf eden hanımın ecrini sadece Allah'tan beklediği belirtilen vakfiyede tarih olarak hicrî 1158 yılı Cümadilûlâ (Cemaziyelevvel) ayı (Haziran 1745) gösterilmiştir. İsminin ve on ikinci cilt olduğunun belirtildiği sayfada ise bazı kitap isimleri verilmiştir.

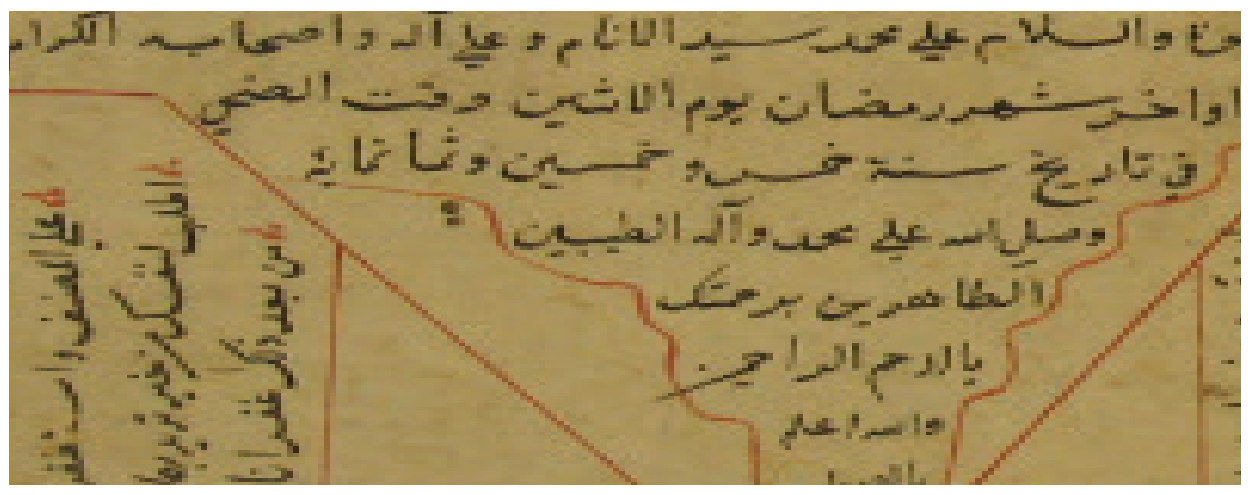

Resim 2. Hacı Paşa Aydın̂̂'nin Mecma 'u'l-envâr adlı tefsirinin on ikinci cildin ferağ kayd

Sonunda ise bu cildin yazımının hicrî 855 yılının Ramazan ayı sonlarında (Ekim 1451) Pazartesi günü kuşluk vakti bittiği belirtilmiştir. ${ }^{61}$ Buna göre eser müellifin vefat tarihinden yaklaşık 30 yıl sonra istinsah edilmiştir. Bu açıdan oldukça önem arz etmektedir.

\subsection{Tefsirin Adı ve Yazılış Zamanı}

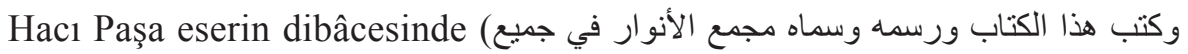

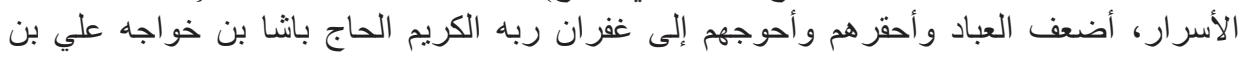
diyerek bizzat kendisi eserinin adını Mec-

61 Hacı Paşa Aydınî, Mecma'u'l-Envâr fî Cemî'i'l-Esrâr, Milli Eğitim Bakanlığı Kastamonu Kitaplığı (Yazma Eserler Kurumu Başkanlığı Kastamonu Yazma Eser Kütüphanesi), nr. 3065, 12: $275 b$. 
ma 'u'l-envâr fì cemî'i'l-esrâr şeklinde koyduğunu belirtmiştir. ${ }^{62}$ Dirâyet yönü ağır basan eser Osmanlı Sultanı II. Murad'a (1421-1451) ithaf edilmiştir. ${ }^{63} \mathrm{Ni}$ tekim yukarıda buna işaret ettik. Eserin yazılış tarihi belirtilmemiştir. Ancak eser 1421 yılında tahta çıkan II. Murad'a takdim edildiğine ve müellif Hacı Paşa da 1423-1424 dolaylarında öldügüne göre eser, 1421-1423 y1lları arasında yazılıp bitirilmiş olmalıdır. ${ }^{64}$

\subsection{Tefsirin Mukaddimesi ve Yazılış Maksadı}

Eserin başında müellif edebî ve akıcı bir üslup ile Allah'a hamdettikten ve Hz. Peygamber'e salat ve selam getirdikten sonra, "emmâ ba' d" diyerek tefsirini

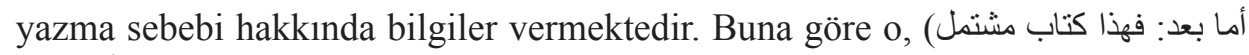

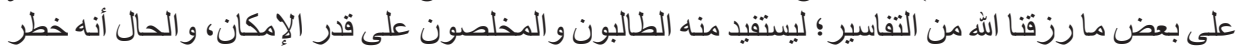

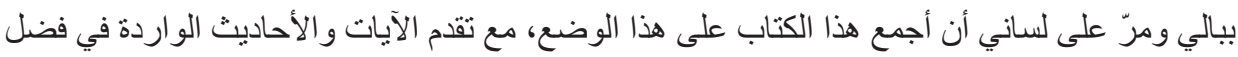
diyrerek bu eseri, talip ve muhlis (istekli ve samimi) dediği kimseler istifade etsinler diye elinde bulunan tefsirlerden yararla-

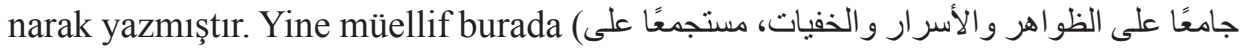
diyerek tefsirinin Kur'ân'ın zâhir anlamlarını, esrâr ve gizli manalarını cem' eden, hakikatleri, ince manaları ve itikâdî konularda söylenenleri bir arada veren bir dirâyet tefsiri olduğunu belirtmiştir. ${ }^{65}$ Uzun süre Misır'da kalmış, dolayısıyla Arapçası gayet iyi olan Aydınî'nin, o dönemlerde bölgede Osmanlı âlimlerince yazılmış bu tarzda herhangi bir tefsirin olmamasını göz önünde bulundurarak tefsiri oluşturduğunu da düşünebiliriz. Gerçi aynı yıllarda Kutbuddin İznikî de -aynen Aydınî gibi Râzî’yi esas alarak- benzer bir tefsir yazmıştır. Ancak dönemin şartları hesaba katıldığında farklı memleketlerde yaşayan bu iki müellifin birbirinden haberlerinin olmadığını söylemek mümkündür.

Müellif bundan sonra ilmin ve âlimin önemine uzun uzadıya değindiği bir mukaddimeye yer vermiş, buna dair bir çok hadis, haber, rivâyet nakletmiştir. ${ }^{66}$

\section{4. İlmin ve Âlimlerin Fazileti Konusu}

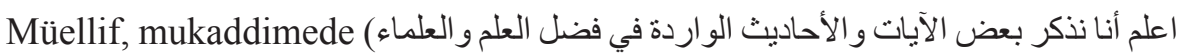
diyerek tefsire

62 Bk. Aydınî, Mecma'u'l-Envâr, 1: 1a.

63 Sakıp Yıldız, “Osmanlı Tefsir Hareketine Toplu Bakış”, Uludağ Üniversitesi Illahiyat Fakültesi Dergisi, cilt 2, say1 1, 1987, s. 7.

64 Ayrıca bk. Abay, “Osmanlı Dönemi Müfessirleri”, s. 17; Öztürk, “Osmanlı Tefsir Kültürüne Panoramik Bir Bakış”, s. 131.

65 Bk. Aydınî, Mecma'u'l-Envâr, 1: 1a. Ayrıca bk. Abay, "Osmanlı Dönemi Müfessirleri”, s. 18.

66 Abay, “Osmanlı Dönemi Müfessirleri”, s. 18. 
başlamadan önce ilmin ve âlimin fazileti konusuna uzunca yer vermekte, serdettiği âyet ve hadislerle konunun önemini ortaya koymaktadır. Bu cümleden

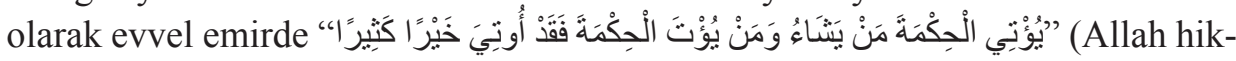
meti dilediğine verir. Kime hikmet verilmişse ona çok büyük bir manevi servet bahşedilmiş demektir) şeklindeki Bakara sûresi iki yüz altmış dokuzuncu âyetini vermektedir. Sonra da "kime hikmet ve Kur'ân verilmiş ise ona Mushaf'tan önce indirilmiş kitapların tamamında verilenlerden daha üstünü ve güzeli verilmiştir" demektedir. Burada geçen "خَيْرًا كَثَيرًا " (çok büyük bir [manevi] servet) ifadesi, Hz. Peygamber'in cevâmi'u'l-kelim (az sözle çok manayı ifade etme) özelliğine

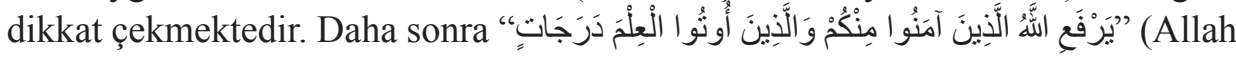
da içinizden yürekten imân edenlerin ve ilim verilenlerin derecelerini yükseltsin) şeklindeki Mücâdele sûresi on birinci âyetini veren müellif, burada "hem imân hem ilim verilmiş olan müminin, imânı olan fakat ilmi olmayan müminden üstün olduğuna dikkat çekildiğini”" söylemektedir.

Dahhak (v. 105/723), "ilim ehlinin Allah katındaki dereceleri, şehitlerin dereceleri gibidir" derken, Mukâtil (v. 150/767) şunu söylemektedir: "Müminler, cennetin kapılarına varınca aralarından âlim olanlara şöyle denir: Cennetin kapısının önünde durun ve insanlara şefaat edin!”.

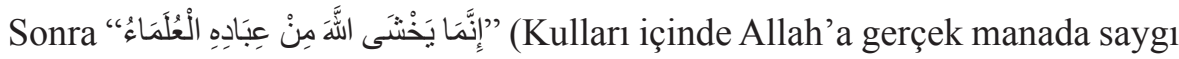
ve bağl1l1k gösterenler, bütün bu hakikatleri hakkıyla anlayıp kavrayan âlim kimselerdir) şeklindeki Fâtır sûresi yirmi sekizinci âyetini şöyle tefsir etmektedir: Âlimler, Allah'ın yaratılışındaki sanatı ve azameti biliyor ve üzerinde düşünüyorlar. Alah'ın sevabının güzelliğini bilip ona göre amel ediyor, ibadet ve ubûdiyetlerini tam yapıyorlar; cezasının dehşetini farkedip ondan sakınıyor, ma'âsîden şiddetle kaçınıyorlar. Müellif, Süfyan Sevrî’nin (v. 161/778) bazı meşâyihten şöyle rivâyet ettiğini nakletmektedir: "Hz. Peygamber'e, 'hangimiz daha iyi biliriz?’ diye soruldu, o da 'en çok korkup sakınanız' dedi”.

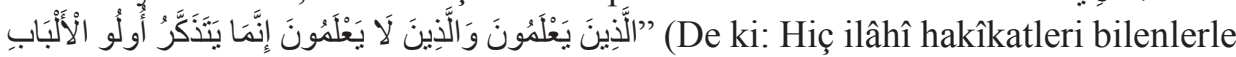
bunların hiçbirini idrak etmeyenler bir olur mu?!) şeklindeki Zümer sûresi dokuzuncu âyetini verdikten sonra şunları söylemektedir: Câhil, asla âlimin derecesine erişemez; yüce dereceler elde etmek konusunda hiçbir zaman âlim ile müsâvî olamaz. Sonra buna delil olmak üzere şu hadisi zikretmektedir: Allah katında fakihten daha faziletli ve değerli biri yoktur; bir fakih şeytan için bin âbidten daha tehlikelidir. Bu dinin direği fikıhtır.

67 Bk. Ebu'l-Leys Nasr b. Muhammed es-Semerkandî, Tefsiru's-Semerkandî el-Musemma Bahru'l-Ulûm, thk. Ali Muhammed Muavvid-Adil Ahmed Abdulmevcûd-Zekeriya Abdulmecid en-Nûtî, Beyrût, Dâru'l-Kutubi'l-İlmiyye, 1413/1993, 3: 85. 
Müellif Hz. Peygamber'in “Dünyada sadece şu iki kişiye gıpta edilmelidir; biri Allah'ın kendisine verdiği malı Hak yolunda harcayıp tüketen, diğeri de Allah'ın kendisine bahşettiği hikmetle insanlar arasında doğru bir şekilde hükmeden ve etrafındakilere bu hikmeti öğreten kimsedir" ${ }^{\prime 6}$ anlamındaki hadisini zikrederek ilmin ve âlimin önemine dikkat çekmektedir. Sonra İbn Abbas'tan şöyle bir rivâyet nakletmektedir: "Öğrendiğiniz ilmi yazın! Allah'ın yedinci kat gökte bulunan bazı melekleri var ki, bunlar fakihler ve ilim öğrenenlere daima istiğfarda bulunurlar. Allah, öğrendiğiniz her bir harfe bedel olarak size bir peygamberin sevabını vermektedir, her gün size bin tane huccet yazmakta ve her gün size bin şehid sevabını takdim etmektedir" ${ }^{69}$

Yine Enes kanalıyla Hz. Peygamber'den şöyle bir hadis nakletmektedir: "Bir kişinin, kendisiyle amel etmek ve başkasına da öğretmek üzere biraz ilim öğrenmesi, bin rekat nafile namaz kılmasından daha hayırlıdır". ${ }^{70}$ Ebu'l-Esved ed-Düelî (v. 69/688) şöyle demiştir: "İlimden daha üstün bir şey yoktur; krallar insanlara hükmeder, âlimler ise krallara hükmederler" ${ }^{71} \mathrm{~Hz}$. Peygamber, "size âlimlerin güzelliklerini anlatmanızı ve hikmetli insanları dinlemenizi tavsiye ediyorum; çünkü Allah Teala, ölü toprağ1 yağmur suyuyla dirilttiği gibi ölü kalbi de ilim ve hikmet nuruyla diriltir" ${ }^{72}$ Müellif bu şekilde çok sayıda hadis ve haberle ilim ve âlimin faziletini, Allah katındaki derecesinin yüceliğini ve bunların ne büyük meziyetler olduğunu anlatmaktadır. ${ }^{73}$

\section{Tefsirin Kaynakları, Ebû Hafs en-Nesefî ve Râzî Tefsirleriyle Mukayesesi}

İstiâzenin başından itibaren uzun bir kısmını incelediğimiz eserde Hacı Paşa büyük oranda Ebû Hafs Necmüddîn Ömer en-Nesefî’nin (v. 537/1143) et-Teysîr fi 't-tefsîr'i ile Fahreddin Râzî'nin (v. 606/1210) Mefâtîhu'l-gayb adlı tefsirlerin-

68 Buhârî, "İlim”, 15.

69 Bk. Cemâluddîn Muhammed b. Abdurrahman Ibn Ömer el-Hübeyşî, Neşru Tayyi 't-Ta'rîf fì Fadli Hameleti'l-İlmi'ş-Şerîf, Cidde, Dâru'l-Minhac, 1997, s. 48-49; el-Hüseyin b. Yahya ez-Zende Veyestî el-Hanefî, Ravdatu'l-Ulemâ ve Nüzhetu'l-Fudalâ, thk. Beşir Berman, Beyrût, Dâru'l-Kutubi'l-İlmiyye, 2020, s. 31-32. Ayrıca bk. aynı yer, dipnot 1.

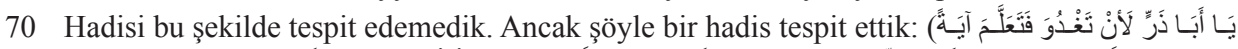

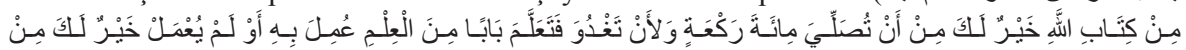

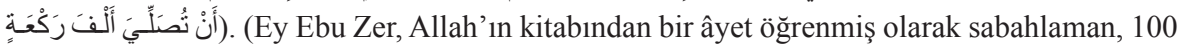
rekât nafile namaz k1lmandan daha hayırlıdır; şayet kendisiyle amel edilen veya edilmeyen bir ilimden biraz öğrenerek sabahlarsan 1000 rekât nafile namaz k1lmadan daha faziletlidir). İbn Mâce, "Kitâbu's-Sünneh", 6.

71 Bk. el-Hübeyşî, Neşru Tayyi 't-Ta'rîff fî Fadli Hameleti'l-İlmi'ş-Şerîf, s. 14.

72 Böyle bir hadis tespit edemedik.

73 Aydınî, Mecma'u'l-Envâr, 1: 1a-5b. 
den istifade etmiştir. Bu iki eser, tefsirin en önemli kaynağıdır. ${ }^{74}$ Abay tefsirin zâhir kısmının neredeyse tamamıyla Râzî'nin tefsirinin ya aynen alınmasına ya da özetlenerek aktarılmasına dayandığını belirtmektedir. Yalnız zaman zaman kendine ait bazı küçük açıklamaları Râzî’nin cümlelerinin arasına koymuştur. Fakat sistematik bakımdan Râzî'den ayrılmaktadır. Râzî’nin tefsirinde ara başlıklar varken, Hacı Paşa tefisirinde hiç başlık kullanmamıştır. Biz de bunları aşağıda vereceğimiz örneklerle göstermeye çalışacağız. Râzî’nin tefsirini adeta kopya edercesine kullandığı halde bu eserden istifade ettiğini belirtmemektedir. Bu son derece dikkat çekicidir. Sadece birkaç yerde "قال الإمام" (İmam şöyle dedi) demektedir. ${ }^{75}$ Bununla Râzî’yi kastettiği anlaşılmaktadır. ${ }^{76}$ Nitekim vr. 51a'da (قالآ (الإمام Sذام (هذه الفو اتيح جائت مختلفة الأعداد) diyeklinde başlayan cümledeki bilgiler aynen Râzî’de geçmektedir. ${ }^{77}$

Bizim tespitlerimize göre Hacı Paşa, Râzî'den çok istifade etmekle beraber ondan daha ziyade Ebû Hafs Nesefî’den yararlanmıştır. Sûre başlarındaki besmelelerin tefsirinden, sûrenin nâzil olduğu yere, nüzul sebebine, sûredeki âyet, kelime ve harflerin sayısına, sûrenin önceki sûre ile ve kendi içindeki uyumuna, sûrenin faziletine kadar pek çok hususta Ebû Hafs Nesefî'nin et-Teysîr'inden alıntı yapmıştır. Bizim üzerinde uzun boylu incelemler yaptığımız on ikinci ciltte de Râzî'nin değil en etkili tefsirin Ebû Hafs Nesefî̀ ile Ebu'l-Leys es-Semerkandî’nin (v. 373/983) tefsirleri olduğunu gördük. Sûre başlarında ağırlıklı olarak Ebû Hafs Nesefî'den, âyetlerin kısa yorumlarında ise Semerkandî'den istifade etmiştir. Ancak konuyla ilgili geniş izahlar ve yorumlar yaptığında Râzî’den yararlandığını görüyoruz.

Abay'ın tespitine göre Ebû Bekir Necmüddîn-i Dâye'nin (v. 654/1256) aynı zamanda 'Aynu'l-hayât ve et-Te'vîlâtu'n-Necmiyye diye de anılan ${ }^{78}$ Bahru'l-hakâik ve'l-meânî fì tefsîri'l-Kur'ân ve's-seb'i'l-mesânî, Abdurrezzak elKâşânî'nin (v. 736/1335) Te'vîlât-ı Kâşâniyye/Te'vîlâtu'l-Kur'ân/Te'vîlu'l-âyât, ${ }^{79}$ Abdülkerim Kuşeyrî'nin (v. 465/1072) Letâifu'l-işârât adlı tefsirleri Hacı Pa-

74 Tawfik, "Hâcî Paşa el-Konevî ve Tefsîruhu Mecma'u'l-Envâr fî̀ Cemî'i'l-Esrâr el-Mucelledu'l-Evvel Dirâse ve Tahkîk", s. 35.

75 Bk. Aydınî, Mecma 'u'l-Envar, 1: 19a, 51a, 134a.

76 Bk. Abay, “Osmanlı Dönemi Müfessirleri”, s. 18.

77 Bk. Fahruddin er-Râzî, Tefsîru'l-Fahr er-Râzî (et-Tefsîru'l-Kebîr Mefâtîhu'l-Gayb), Beyrût, Dâru'l-Fikr, 1401/1981, 2: 13.

78 Bk. Hamid Algar, "Bahrü’l-Hakâik ve'l-Meân̂̂”, Türkiye Diyanet Vakfi İslam Ansiklopedisi, İstanbul, Türkiye Diyanet Vakfi Yayınları, 1991, 4: 515516-.

79 Bk. Süleyman Uludağ, "Kâşânî, Abdürrezzâk", Türkiye Diyanet Vakfi İslam Ansiklopedisi, İstanbul, Türkiye Diyanet Vakfı Yayınları, 2002, 25: 56-. 


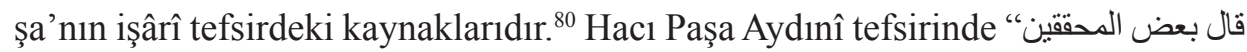

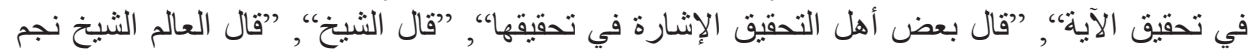
"gibi ifadeleri kullandığında Necmüddîn-i Dâye’yi ve eserini kastetmiş oluyor.” “" gibi ifadeler de Kâşânî’yi ve tefsirini göstermektedir. (المعرفة) veya (قال بعض أهل التفسير) dediğinde Ebû Hafs Nesefî’yi; (فال الإمام) dediğin-

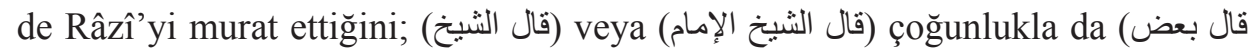
فال العالم) dediğinde Necmüddîn'i kast ettiğini belirtiyor. Aydınî bazen (أهل التحقيق diyerek açık bir şekilde Necmüddîn'in adını zikrediyor. Aydınî veya (قال أهل التأويل), (قال بعض العلماء من أهل التأويل) dediğinde ise İbnu'l-Arabî'yi v. 638/1241) murad ediyor. ${ }^{83}$

Tawfik, müellifin bilhassa dört eserden istifade ettiğini belirtiyor. Ona göre bunlar Ebû Hafs en-Nesefî'nin et-Teysîr fî̀t-tefsîr, Fahreddin Râzî'nin Mefâtîhu'l-gayb, Necmüddin-i Kübra'nın ${ }^{84}$ (v. 618/1222) et-Te'vîlâtu'n-Necmiyye ve Muhyiddin İbnu'l-Arabî'nin Tefsîru İbni'l-Arabî adlı tefsirleridir. ${ }^{85}$ Bizim on ikinci ciltteki tespitlerimize göre Aydınî, Ebu'l-Leys es-Sermekandî’nin tefsirinden de faydalanmıştır. Nitekim aşağıda buna dair örnekler vereceğiz.

Yukarıda müellifin tefsirdeki yöntemi ve muhtelif âyetleri işleme tarzından bahsederken verilen örneklerin neredeyse aynen Ebû Hafs Nesefî’nin veya Râzî’nin tefsirinde de geçtiğine işaret ettik. Burada ise seçeceğimiz muhtelif sayfalarda Ebû Hafs Nesefî ve Râzî tefsiriyle birebir mukayesesini yapacağız. Böylece verilen örnekler üzerinden bunlardan ne kadar ve hangi ölçülerde istifade ettiğini tespit etmeye çalışacağız.

Bu konuya iki müellifin eserinin başından başlamak istiyoruz. Râzî tefsirinin başında giriş veya önsöz yerine Fâtiha sûresini küçük bazı açıklamalarla birlikte vermekle yetinmiş, ardından "emmâ ba'd" diyerek bunun, Fâtiha sûresinin kapsadığı ilimlerden Allah'ın kendisine lütfettiği bazı açıklamaları ihtiva eden bir kitap olduğunu belirtiyor. Sonra el-faslu'l-evvel başlığı altında istiâze kısımın-

80 Abay, “Osmanlı Dönemi Müfessirleri”, s. 18.

81 Aydınî, Mecma'u’l-Envâr, 1: 102a, 139b, 221a, 223a. Ayrıca bk. Abay, "Osmanlı Dönemi Müfessirleri", s. 18.

82 Aydınî, Mecma'u'l-Envâr, 1: 103b, 120a, 203a. Ayrıca bk. Abay, “Osmanlı Dönemi Müfessirleri", s. 19.

83 Tawfik, "Hâcî Paşa el-Konevî ve Tefsîruhu Mecma'u'l-Envâr fî̀ Cemî'i'l-Esrâr el-Mucelledu'l-Evvel Dirâse ve Tahkîk", s. 41-42.

84 Eser Necmüddîn Dâye’ye ait olup yanlışlıkla Necmüddîn Kübrâ'ya isnad edilmiştir (Bk. Algar, "Bahrü'l-Hakâik ve'l-Meânî”, 4: 515-516).

85 Tawfik, "Hâcî Paşa el-Konevî ve Tefsîruhu Mecma'u'l-Envâr fî Cemî'i'l-Esrâr el-Mucelledu'l-Evvel Dirâse ve Tahkîk", s. 31-42. 
dan bahsediyor. Müellif Aydınî ise mukaddimede bazı bilgiler verdikten sonra ilim ve âlimin faziletinden bahsediyor. Bu konuyu ne Ebû Hafs Nesefî’nin ne de Râzî’nin tefsirinde göremedik. O da bundan sonra istiâzeye geçiyor. Şimdi iki tefsirde bu kısmı mukayese edelim:

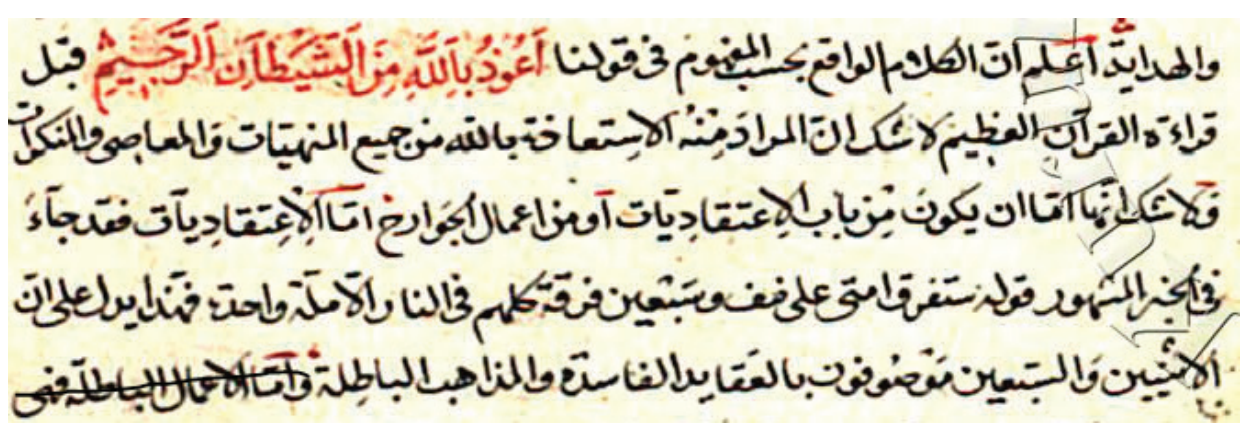

Resim 3. Aydınî, Mecma'u'l-envâr, 1: 5b.

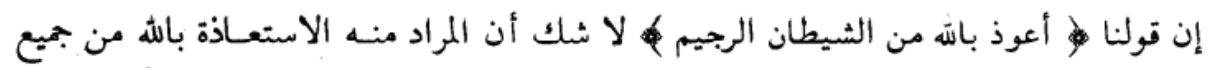

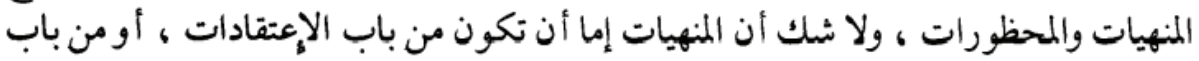

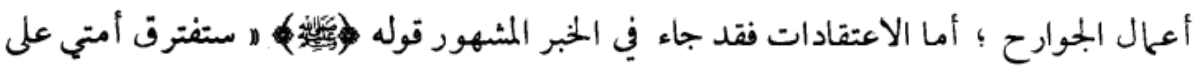

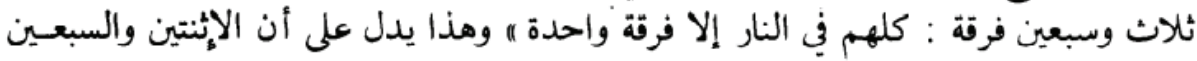

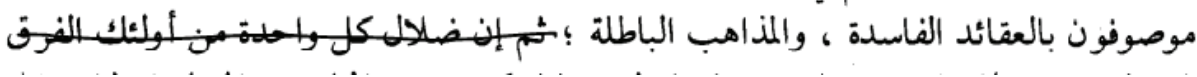

Resim 4. Râzî, Mefâtîhu'l-gayb, 1: 12.

Görüldüğü gibi iki tefsirde bu kısım arasında büyük bir benzerlik vardır. Sadece Aydınî, eûzudan sonra (قبل قرائة القرآن العظيم) şeklinde bir ibare vermiştir ki,

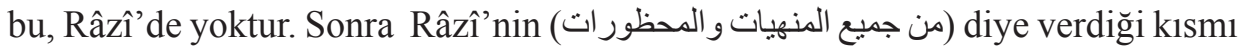
(من جميع المنهيات و المعاصي و المنكر ات) (تثلاث وسبعين) kism1,

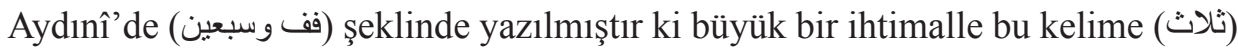
kelimesinin yanlış yazılmış halidir. Yine Râzî’nin (فرقة) وفة واحدة) şeklinde verdiği kelimeyi Aydınî (ملة واحدة) diye vermiştir. Onun dışındaki kısımlar aynıdır. Râzî dedikten sonra on iki satırda konuyla ilgili bazı açıklamalar vermiş, daha sonra (وأما الأعمال الباطلة) kısmına geçmiştir. Aydınî ise bu on iki satırlık bilgiyi atlamış, hemen (وأما الأعمال الباطلة) kısmına geçmiştir. Râzî bundan sonra Fâtiha sûresini verip besmeledeki isimden itibaren bazı açıklamalar yapmaktadır. Bu şekilde Fâtihadaki bütün kelimeleri tek tek izah etmektedir. Sonra az lafızdan çok mesele çıkarmanın hükmü, bu sûreden çok mesele çıkarmanın daha başka delilleri, kelimeyle ilgili meseleler, ses ve harflerden çıkarılan hususlar, isim, fiil ve harflerle ilgili hususlar, ismin çeşitleri, fiilin irabı, istiâze nin tefsirindeki aklî ve naklî hususlar, eûzudan çıkarılan fikhî hükümler gibi muhtelif konular üze- 
rinde uzun uzadıya durmaktadır. Aydınî yaklaşık altmış sayfa tutan ${ }^{86}$ bu ksımın tamamını atlamış ve sayfa yetmiş birden itibaren devam etmiştir.

\section{䒠

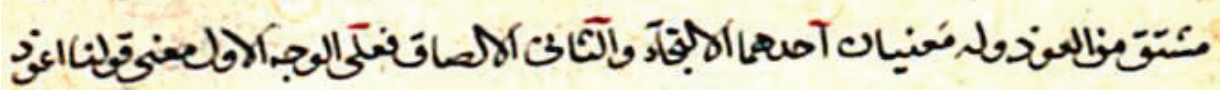

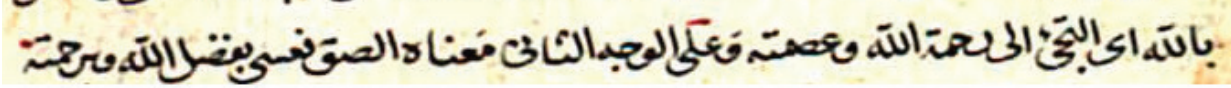

Resim 5. Aydınî, Mecma 'u'l-envâr, 1: 5b.

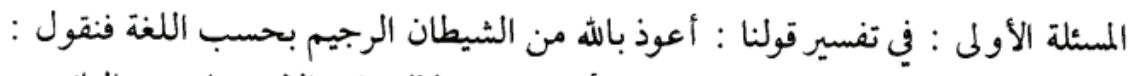

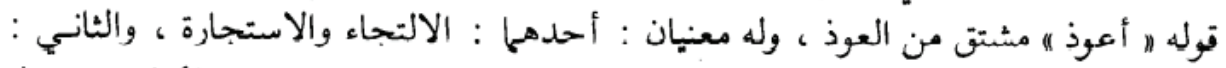

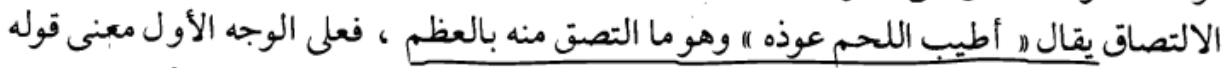

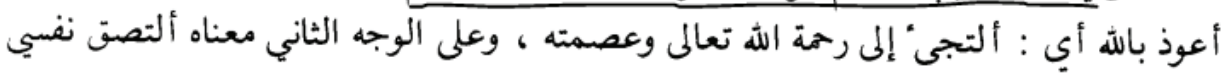

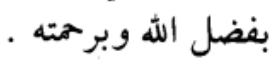

Resim 6. Râzî, Mefâtîhu'l-gayb, 1: 71

Burada Aydınî’nin ufak bazı müdahalelerle Râzî’nin ibaresini birebir ald1-

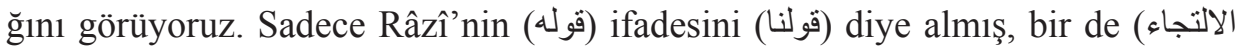

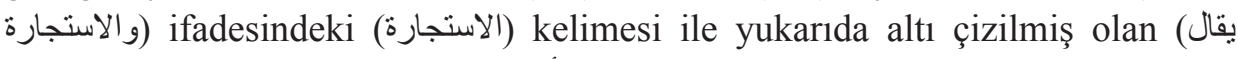
cümlesini tefsirine almamıştır, geri kalan kisımlar tamamen aynidır.

\section{'

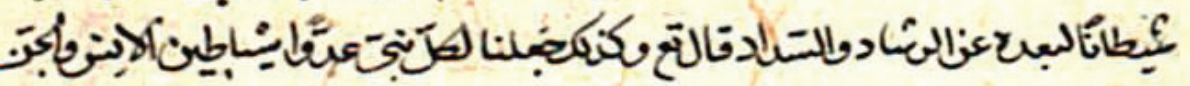

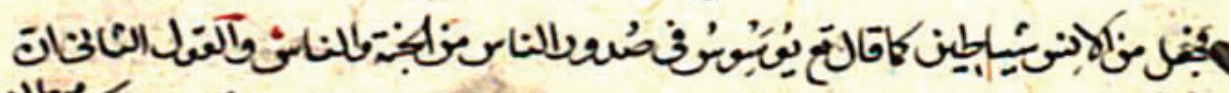

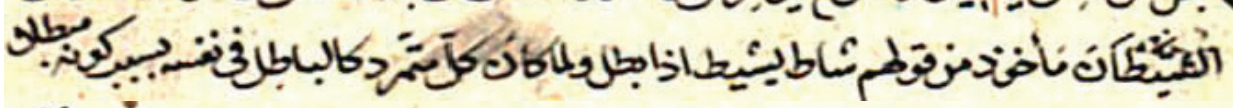

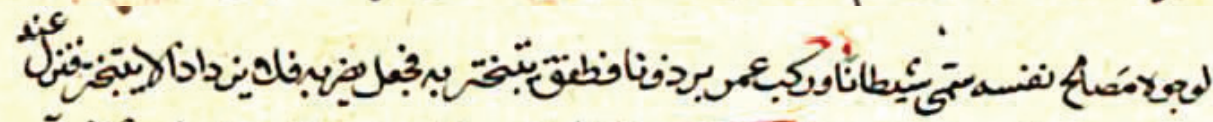

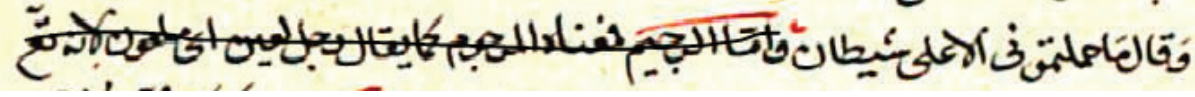

Resim 7. Aydınî, Mecma'u'l-envâr, 1: 5b-6a.

86 er-Râzî, Mefâtîhu'l-Gayb, 1: 12-71. Râzî'nin tercümesinde bu kısım doksan sayfa civarındadır. Bk. Fahreddin er-Râzî, Tefsîr-i Kebîr Mefâtîhu'l-Gayb, trc. Suat Yıldırım - Lütfullah Cebeci Sadık Kılıç - Sadık Doğru, İstanbul, Huzur Yayınevi, ts., 1: 2-88. 


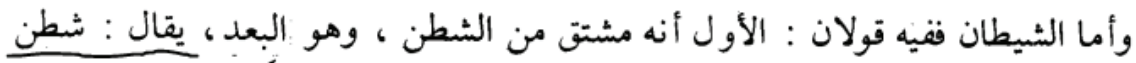

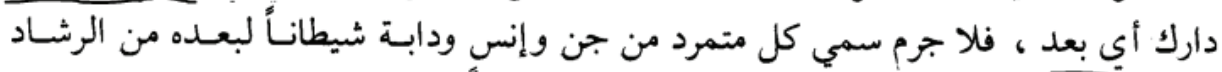

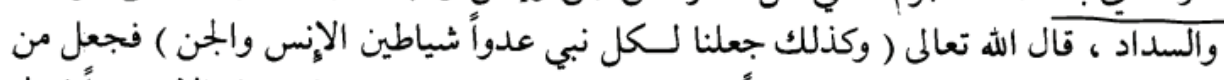

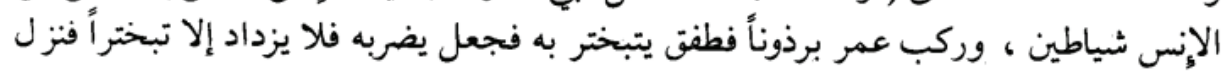

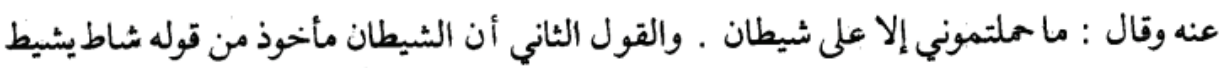

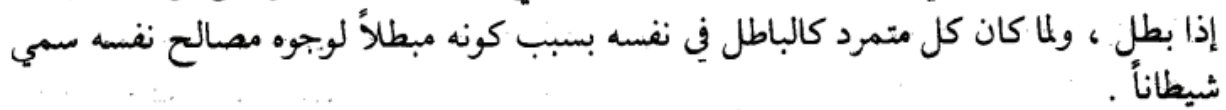

Resim 8. Râzî, Mefâtîhu'l-gayb, 1: 71-72.

Burada da Aydınî, yine bazı müdahaleler yaparak birebir Râzî’ den alıntı yapmıştır. Şeytan kelimesinin kökünü verirken (مشتق من الثطن) demesi gerekirken (مشتق من البعد) demiş̧tir. Burada (الثطن) kelimesi yanlışlıkla eksik kalmıştır. Zira kelimesinin (البعد) kelimesinden müştak olması mümkün değildir. Ayrıca altı çizili yer atlanmıştır. Öte yandan Râzî’ de de geçtiği gibi (فجعل من الإنس شياطين)

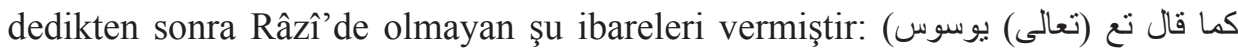
وركب عمر برزونا فطفق يتبختر به فجعل) Öte yandan Râzî (في صدور الناس من الجنة و الناس

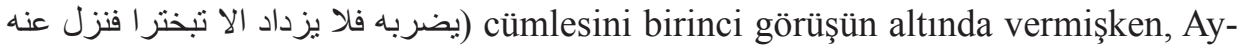
dınî ikinci görüşte vermiştir.

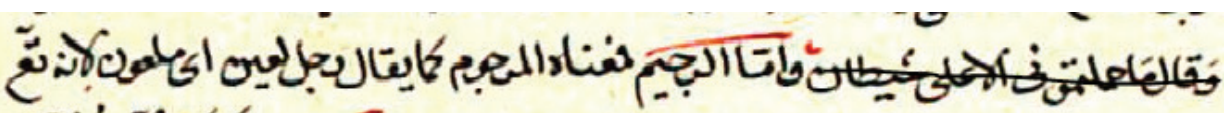

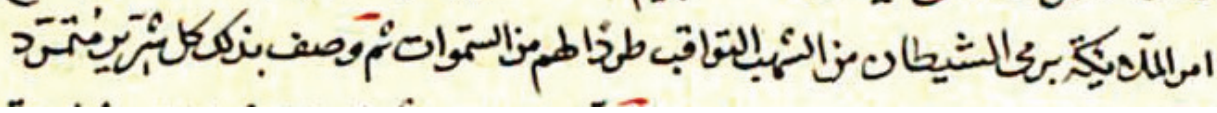

Resim 9. Aydınî, Mecma'u'l-envâr, 1: 6a.

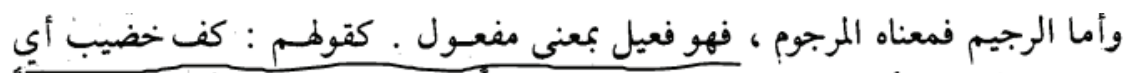

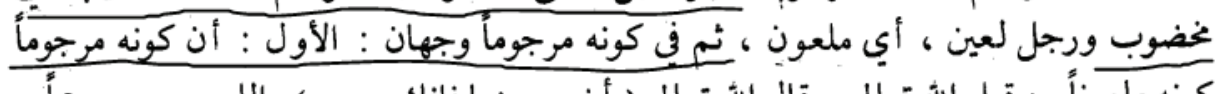

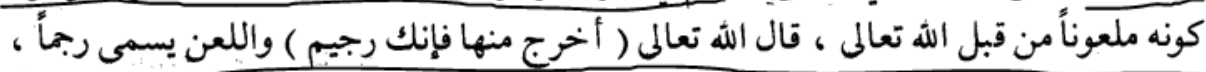

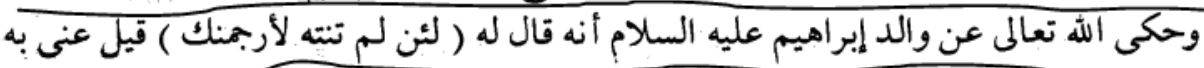

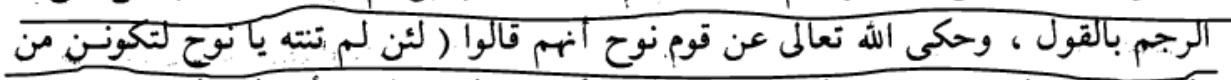

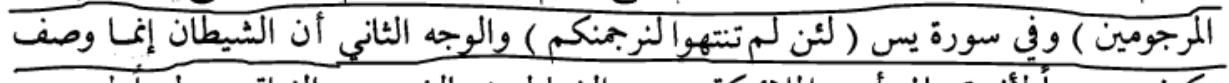

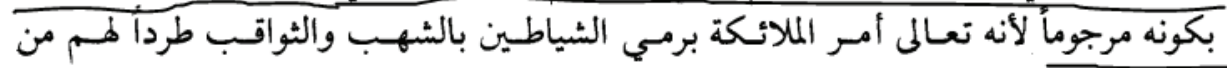

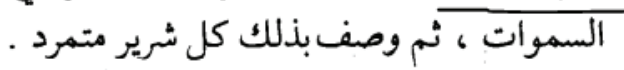

Resim 10. Râzî, Mefâtîhu'l-gayb, 1: 72. 
Burada da Aydınî’nin ihtisarlara gittiği ve altı çizili kısımları atladığı ve cümleleri birleştirdiği görülmektedir. Ayrca birleştirmeyi yaparken araya (كما يقال) ifadesini eklemiştir.

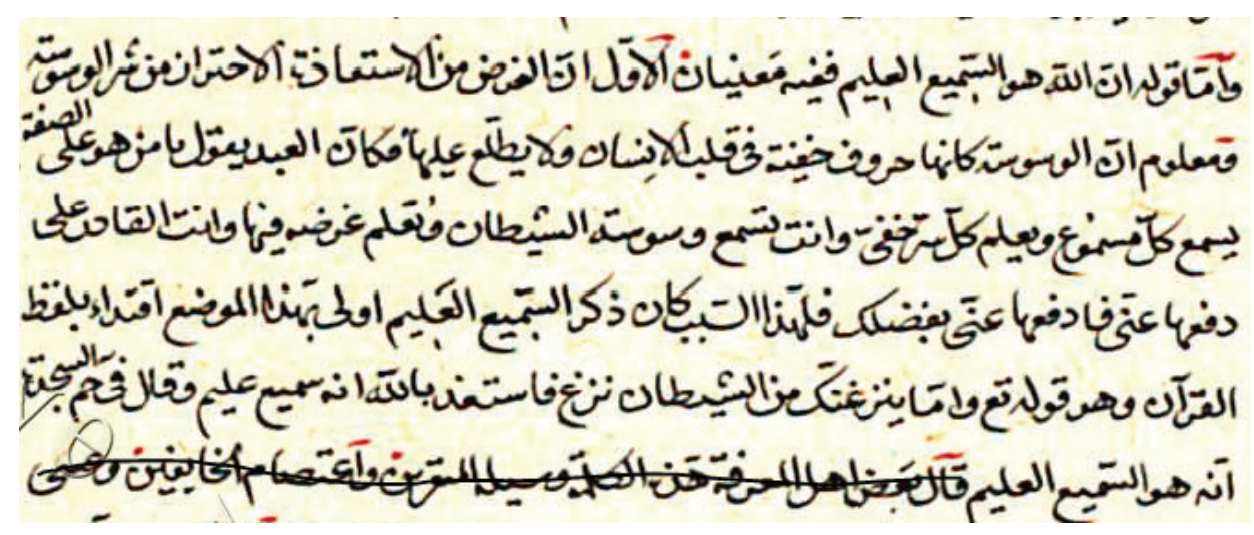

Resim 11. Aydınî, Mecma'u'l-envâr, 1: 6a.

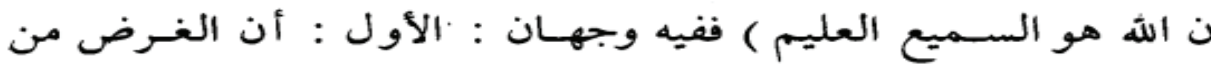

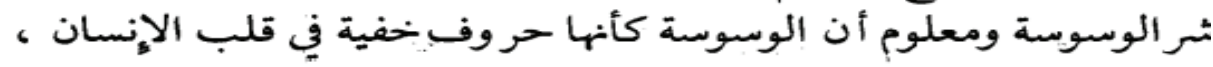

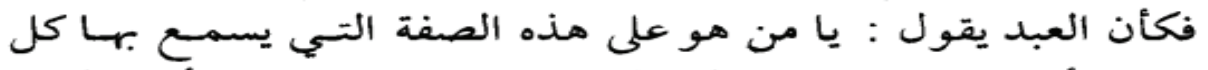

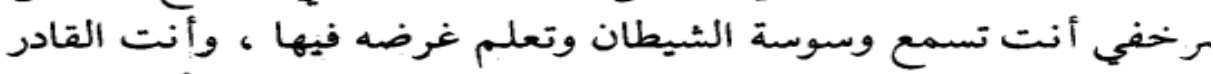

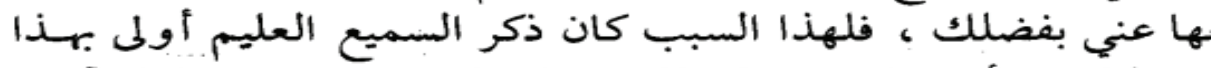

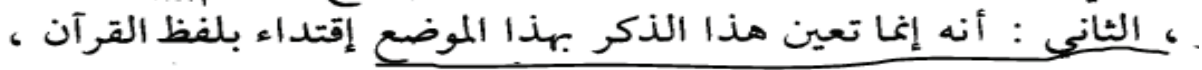

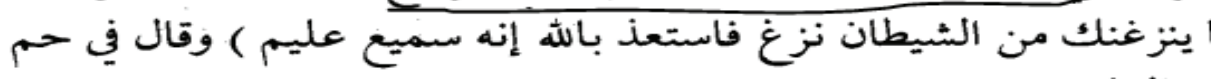
C

Resim 12. Râzî, Mefâtîhu'l-gayb, 1: 72.

Burada altı çizili kısım hariç geri kalan kısımlar iki tefsirde de aynıdır. Bundan sonra Aydınî, Râzî'de olmayan ${ }^{87}$ şu ifadelere yer vermektedir:

87 Bunun için Râzî’nin tefsirinde istiâzeyle ilgili bütün kısımları inceledik, fakat bulamadık. erRâzî, Mefâtîhu'l-Gayb, 1: 72-223. 


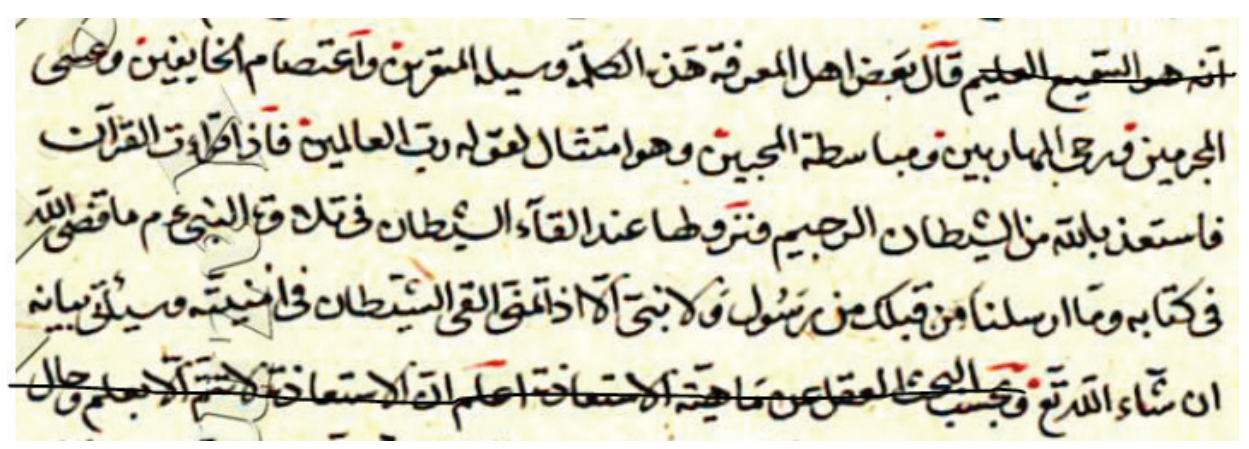

Resim 13. Aydınî, Mecma'u'l-envâr, 1: 6a.

Bu ibareler birebir Ebû Hafs Nesefî tefsirinde geçmektedir:

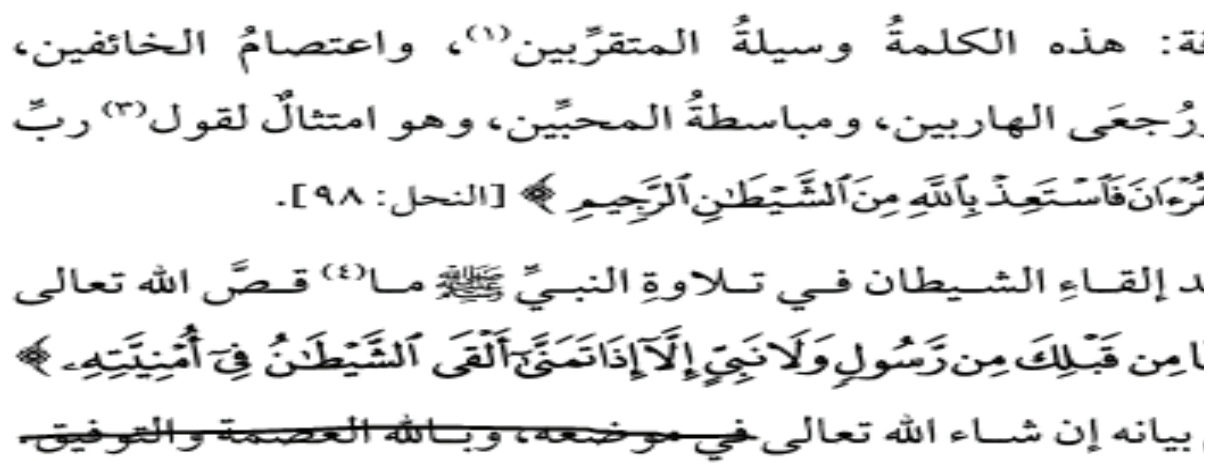

Resim 14. Ebû Hafs Nesefî, et-Teysîr fít-tefsir, 1: 19.

Ebû Hafs Nesefî, (قال أهل المعرفة) demişken, Aydınî (قال بعض أهل المعرفة) demiştir. Bundan anlıyoruz ki, aslında Aydınî (قال بعض أهل المعرفة) derken yukarıda belirtildiği üzere Ebû Hafs Nesefî’yi kast etmemiştir. Yine Aydınî (قال نجم الدين) derken, bunları yukarıda belirtildiği üzere Necmüddin-i Kübrâ/Dâye'den almamıştır, çünkü aynı ifade Ebû Hafs Nesefî’de de (قال نجم الدين) diyerek verilmektedir ve tahkiki yapanlar bununla müellif Ebû Hafs Nesefî'nin kast edildiğini belirtmişlerdir. ${ }^{88}$ Biz de Necmuddin-i Kübra'ya atfedilen et-Te'vîlâtu'n-Necmiyye'ye baktık, ${ }^{89}$ fakat böyle bir ibare görmedik.

88 Bk. Ebu Hafs Necmuddin b. Ömer b. Muhammed en-Nesefî, et-Teysîr fi t'tefsîr, thk. Mahir Edib Habbûş, İstanbul, Dâru'l-Lübâb, 1440/2019, 1: 39, dipnot 3.

89 Bk. Ahmed b. Ömer Necmuddin el-Kübrâ, et-Te'vîlatu'n-Necmiyye fi 't-Tefsîri'l-İşârî es-Sûfî, thk. Ahmed Ferdi el-Mezyudî, Beyrût, Dâru'l-Kutubi'l-İlmiyye, 2009, 1: 57-102. Bu tefsir üzerinde Kübrâ'nın adı yazılmış olmakla birlikte aslında Necmeddin Dâye’ye aittir. 
Aynı ifâde İsmail Hakkı Bursevî'nin (v. 1137/1725) Rûhu'l-beyân adlı tefsirinde de geçmektedir. ${ }^{90}$ Muhtemelen Rûhu'l-beyân da buradan almıştır.

Aydınî’nin tefsirinde 6a-6b arası bazı ihtisarlarla aynı ibarelerle Râzî'nin tefsirinde geçmektedir. ${ }^{91}$ Sonra Râzî tefsirinden 75-79 arası atlanmış, 79'dan itiba-

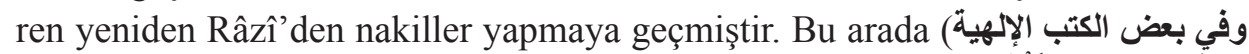

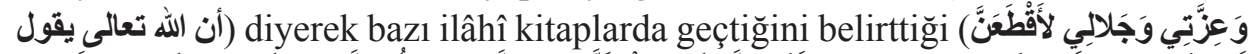

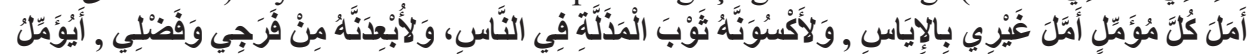

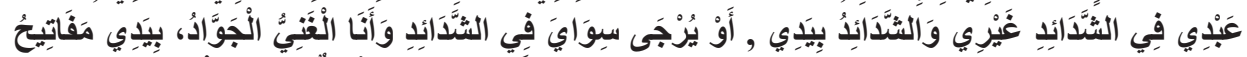
şeklinde uzun bir hadis vermektedir. ${ }^{92}$ Sonra diyerek bir haber nakletmektedir. Bu haber aynen Râzî'de de geçmektedir. Ancak Râzî bunu (أنه قد انكثف لأرباب البصائر) diyerek vermektedir.93 Burada insan bedeniyle cehennem arasında bir benzerlik kurulmakta ve tıpkı cehennemde olduğu gibi insan bedeninde de 19 zebaninin olduğu ve bunların ne olduğu hususu açıklanmaktadır.

Aydınî (وقال بعض المحقِين) diyerek bir rivâyet vermektedir. Râzî ise bu ifadeyi kullanmadan o haberi kendi cümleleri içinde vermektedir. Buna göre müellifin derken Râzî’yi kast ettiği netleşmiş oluyor:

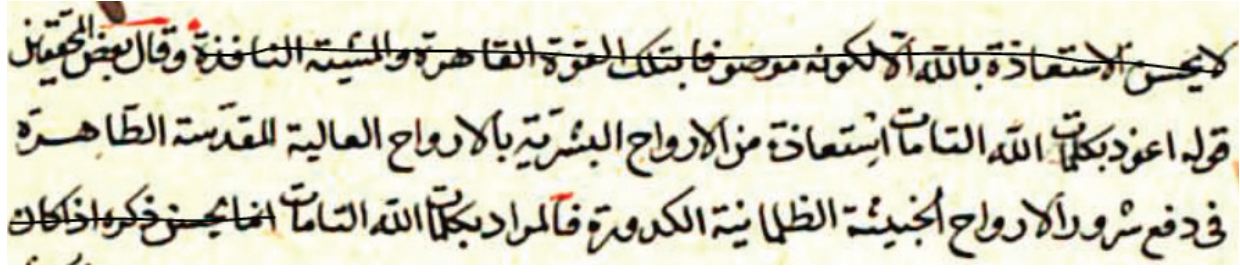

Resim 15. Aydınî, Mecma'u'l-envâr, 1: 7a

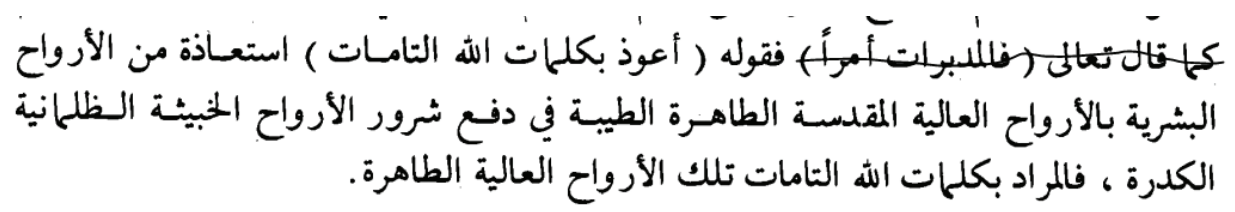

Resim 16. Râzî, Mefâtîhu'l-gayb, 1: 79.

Aydınî, son cümledeki (تلك الأرواح العالية الطاهرة) kısmını eksik bırakmış, altındaki paragrafa geçmiştir. 7a-b'de bazı ihtisarlarla beraber aynı ifadeler mev-

90 İsmail Hakk1 Bursevî, Rûhu'l-Beyân, İstanbul, Matbaatu'l-Osmaniyye, 1330, 1: 3.

91 er-Râzî, Mefâtîhu'l-Gayb, 1: 72-75.

92 Aydınî, Mecma'u'l-Envâr, 1: 6 b.

93 er-Râzî, Mefâtîhu'l-Gayb, 1: 74-75. 
cuttur. ${ }^{94}$ Aydınî, Râzî tefsirinden 83-97 arasını atlamış, 97'den sonra ihtisarlarla

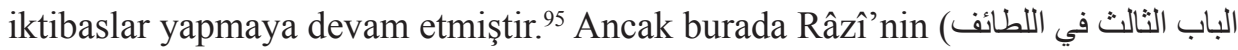
başlığı altında (المستنبطة من قولنا أعوذ بالله من الثنيطان الرجيم diye nükteler

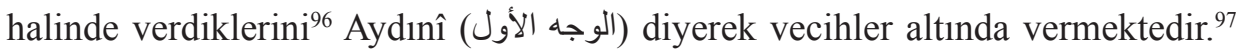
Aydınî çoğu yerde (وجه آخر) diyerek hangi vecih olduğunu da belirtmiyor. Oysa Râzî bu kısımda 19 nükte zikretmektedir. Ayrıca Râzî’nin (عروج من الخلق إلى الخالق (آلى (عروج) diye verdiğgi yeri ${ }^{98}$ Aydınî (خروج من الخلق إلى الخالق) şeklinde vermiştir. ${ }^{99}$ Aydınî’nin diyerek verdiği kısım ${ }^{100}$ da yine (قال أرباب الإشارة) başlığ1 altında aynen geçmektedir. ${ }^{101}$

Râzî tefsirinde 108-114 arasında bulunan bilgilerden bazı kısımlar Aydınî tefsirinde atlanmış bazı kısımlar ise aynen yer almıştır. ${ }^{102}$

Yine Râzî tefsirinde 114-160 arası atlanmıştır. 160’ta المسألة الثالثة رأيت في بعض (كير) (كتب التذكير şeklindeki ifade Aydın̂̂’de (وفي بعض كتب التذكير) şeklindedir. ${ }^{103}$ Sonra Allah Teâlâ'nın dört bin adının olduğu; bunların bininin Kur'ân'da, bininin Tevrat'ta, bininin İncil'de ve bininin de Zebur'da geçtiği hususu anlatılmaktadır. ${ }^{104}$

Aydınî tefsirinde Râzî'nin tefsirinin 160-162. sayfaların arasını vermemiştir. 162-168. sayfalar arası bazı kısımlar atlanarak verilmiştir. ${ }^{105} 168-173$. sayfalar arası yoktur, fakat 173-179. sayfalar arası aşağı yukarı aynen verilmiştir. Râzî'de bu sayfalar arasında Mûsâ Peygamber, Râbia ve daha başkalarıyla ilgili hikaye ve rivâyetlerin bulunduğu yirmi dört nükte vardır; Bu hikâyeler birebir Aydınî'de de mevcuttur. ${ }^{106}$

Müellif 12a'da (الحكمة) diye bir başlık attıktan sonra Allah Teâla'nın Kur'ân'ın başında kullanmayı tercih ettiği ilk harfin "elif" veya başka bir harf değil de "be" olmasındaki hikmetle ilgili uzun bazı bilgiler vermekte, harflerin manaları ve hikmetleri üzerinde geniş şekilde durmaktadır. Râzî’de olmayan bu bilgileri nereden

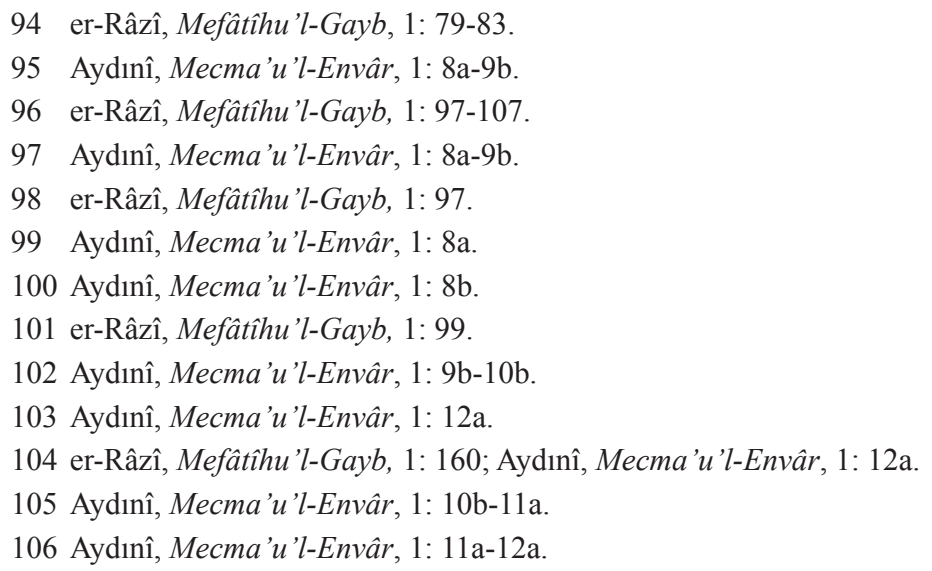


aldığını belirtmemiştir. Ancak bu bilgiler esasında Necmuddin-i Dâye'ye ait olan fakat Necmeddin-i Kübra'ya atfedilen et-Te'vîlâtu'n-Necmiyye adlı tefsirde bulunmaktadır. ${ }^{107}$ Eserde bu konuda on madde altında bilgiler verilmektedir. Aydınî, bu eserdeki bilgileri olduğu gibi tefsirine aktarmış, bazen küçük bazı müdahaleler yapmıştır. ${ }^{108}$ Sonra yine harflerin manaları ve hikmetleriyle ilgili geniş bilgiler vermektedir. ${ }^{109}$ Bütün bunlar da bazı müdahalelerle aynen et-Te'vîlâtu'n-Necmiy$y e$ 'den alınmışlardır. ${ }^{110}$ Sonra Te'vîlât'ın 73-75 arasındaki sayfalarda yer alan hususlar atlanmıştır. 75'ten 82'ye kadarki sayfalarda bulunan hususlar ise Aydınî' de mevcuttur. ${ }^{11}$

Müellif daha sonra Rahman ve Rahim sifatlarıyla ilgili olarak yine et-Te'vîlâtu'n-Necmiye'den ve Ebû Hafs Nesefî' den alıntı yapmaktadır. ${ }^{122}$ Ancak orada olmayan bazı bilgiler de veriyor ki onları başka yerde bulamadık. ${ }^{113}$ Daha sonra (الحمد اله رب العالمين) kısmının tefsirine geçmektedir. ${ }^{114}$ Buradaki bilgiler Râzî’nin tefsirinde verilenlerle örtüşüyorsa da aynısı olduğunu söyleyemeyiz. ${ }^{115}$ Ancak Ebû Hafs Nesefî’nin tefsirindekilerle birebir örtüşüyor, ${ }^{116}$ dolayisiyla bu hususta müellifin kaynağı Ebû Hafs Nesefî̀ dir. Sonra sûrenin indiği yerle ilgili bilgiler vermektedir. ${ }^{117} \mathrm{Bu}$ bilgiler de ağırlıklı olarak Ebû Hafs Nesefî' de ve Râzî'de mevcuttur. ${ }^{118}$ Sonra sûrenin kaç âyet, kaç kelime ve kaç harften ibaret olduğunu zikredip sırları hakkında bilgi vermektedir. ${ }^{119}$ Bunları olduğu gibi Ebû Hafs Nesefî’nin tefsirinde bulmak mümkündür. ${ }^{120}$ Sonra Fâtiha'nın Allah ile kul arasında taksim edildiğiyle ilgili hadis, Fâtiha'nın isimleri ve bunların manaları hususu zikredilmektedir. ${ }^{121} \mathrm{Bu}$ hususlar Ebû Hafs Nesefî̀ ve Râzî'nin tefsirinde,

107 el-Kübrâ, et-Te'vîlatu'n-Necmiyye, 1: 62-64.

108 Aydınî, Mecma'u'l-Envâr, 1: 12a-13a.

109 Aydınî, Mecma'u'l-Envâr, 1: 13a-15a.

110 el-Kübrâ, et-Te'vîlatu'n-Necmiyye, 1: 64-73.

111 Aydınî, Mecma'u'l-Envâr, 1: 15a-16a.

112 Bk. el-Kübrâ, et-Te'vîlatu'n-Necmiyye, 1: 84-86; en-Nesefî, et-Teysîr fi 't-Tefsîr, 1: 51-67; Aydınî, Mecma'u'l-Envâr, 1: 116a-b.

113 Aydınî, Mecma'u'l-Envâr, 1: 16a-b.

114 Aydınî, Mecma'u'l-Envâr, 1: 16b.

115 er-Râzî, Mefâtîhu'l-Gayb, 1: 183-184.

116 en-Nesefî, et-Teysîr fì t'-Tefsîr, 1: 71-72.

117 Aydınî, Mecma'u'l-Envâr, 1: 16b.

118 Bk. en-Nesefî̀, et-Teysîr fi 't-Tefsîr, 1: 74-75; er-Râzî, Mefâtîhu'l-Gayb, 1: 183-184.

119 Aydınî, Mecma'u'l-Envâr, 1: 16b-17a.

120 en-Nesefî, et-Teysîr fít-Tefsîr, 1: 72-73.

121 Aydınî, Mecma'u'l-Envâr, 1: 17a-18b. 
geçmektedir. ${ }^{122}$ Ancak müellifin bu konudaki kaynağı Ebû Hafs Nesefî'dir. Aydınî, Hz. İbrahim'in “ya Rabbî sana hamd edene ne karş1lık vereceksin?” şeklindeki sorusu ile Hz. Ali'nin, Allah'1n aklı gizli bir nurdan yarattığı şeklindeki sözüyle ilgili bilgileri verdikten sonra ${ }^{123}$-ki bu bilgileri aynen Râzî'den almıştır-124 (وقال الإمام) diyerek mahlûkâtın ilk mertebesinin akıl olduğu yönünde bilgiler vermektedir. ${ }^{125}$ Burada sözünü ettiği imam Râzî'dir. Nitekim bu bilgiler aynen Râzî' de geçmektedir. ${ }^{126}$

Fâtiha sûresinin geri kalan kısımlarında da Ebû Hafs Nesefî̀ ve Râzî'den önemli oranda etkilendiğini söyleyebiliriz. Ancak buralarda Ebû Hafs Nesefî ve Râzî'de ayrıca Te'vîlât'ta da rastlamadığımız, başka yerde de bulamadığımız ilgi çekici bilgiler verilmekte ve Fâtiha'nın tefsiri uzun uzadıya yapılmaktadır. ${ }^{127}$ Ebû Hafs Nesefî ve Râzî gibi Aydınî de Fâtiha sûresini oldukça geniş kapsamlı bir şekilde ele almıştır.

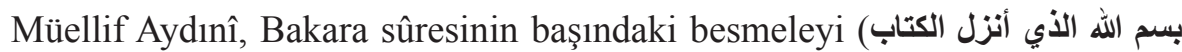
128 (بلا ريب الرحمن الذي لطيف بالمؤمنين المتقين بالغيب الرحيم الذي ستر على المقصرين ستر الغيب

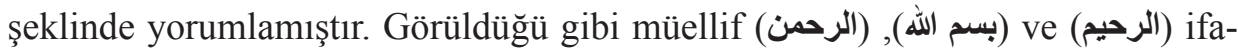
delerini sûrenin muhtevasına uygun bir şekilde açıklamıştır. Müellif bu ifadeyi birebir Ebû Hafs Nesefî'den almıştır. ${ }^{129}$ Ebû Hafs Nesefî de aynı şekilde tefsir etmiştir. ${ }^{130} \mathrm{O}$ diğer bütün sûrelerin başındaki besmeleleri de sûrenin muhtevasına uygun bir şekilde birbirinden farklı olarak yorumlamıştır.

Yine Aydınî, Bakara sûresinin baş kısmını da Râzî’ den almıştır. ${ }^{131}$ (الم) ile ilgili verilen diğer bilgiler de çoğunlukla aynen, bazen de bir takım ihtisarlarla Râzî' den alınmıştır. ${ }^{132}$

Müellif Aydınî, Mücâdele sûresinin başındaki besmeleyi şöyle yorumlamıştır:

122 Bk. en-Nesefî, et-Teysîr fi 't-Tefsîr, 1: 76-90; er-Râzî, Mefâtîhu'l-Gayb, 1: 273, 179-183.

123 Aydınî, Mecma'u'l-Envâr, 1: 19a.

124 er-Râzî, Mefâtîhu'l-Gayb, 1: 287.

125 Aydinî, Mecma'u'l-Envâr, 1: 19a.

126 er-Râzî, Mefâtîhu'l-Gayb, 1: 287.

127 Bk. Aydınî, Mecma 'u'l-Envâr, 1: 18b-49a. Ayrıca bk. en-Nesefî, et-Teysîr fi 't-Tefsîr, 1: 90-180; er-Râzî, Mefâtîhu'l-Gayb, 1: 185-293.

128 Aydınî, Mecma'u'l-Envâr, 1: 49a.

129 Bk. Geniş bilgi için bk. Tawfik, "Hâcî Paşa el-Konevî ve Tefsîruhu Mecma'u'l-Envâr fî Cemî'i'l-Esrâr el-Mucelledu'l-Evvel Dirâse ve Tahkîk", s. 68-69.

130 en-Nesefî, et-Teysîr fi 't-Tefsîr, 1: 183.

131 Bk. Aydınî, Mecma 'u'l-Envâr, 1: 49a; er-Râzî, Mefâtîhu'l-Gayb, 2: 3.

132 Bk. Aydınî, Mecma 'u'l-Envâr, 1: 49a-51a; er-Râzî, Mefâtîhu'l-Gayb, 2: 3-10. 


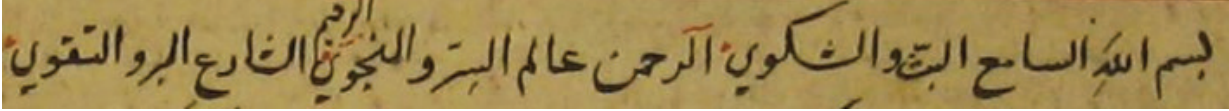

Resim 17. Aydinî, Mecma'u'l-envâr, 12: 1a.

Ebû Hafs Nesefî tefsirinde ise şöyledir:

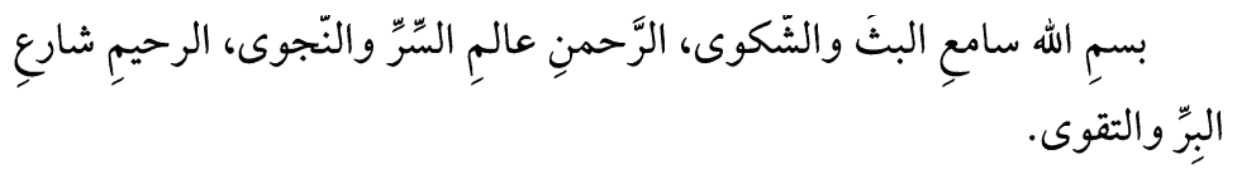

Resim 18. Ebû Hafs Nesefî, et-Teysîr fi't-tefsîr, 14: 315.

Görüldüğü gibi iki ifade aynıdır. ${ }^{133}$ Buna göre bu kısmı Aydınî, olduğu gibi Ebû Hafs Nesefî'den almıştır. Sûrenin nerede indiği, âyet, kelime ve harf sayısı, münasbâtı ve fazileti konusunda verilen bilgiler de aynen Ebû Hafs Nesefî'den nakledilmiştir. ${ }^{134}$ Müellif âyetin manasını da yine Ebû Hafs Nesefî' den almış, ${ }^{135}$ ancak sûrenin sebeb-i nüzûluyla ilgili İkrime'den naklettiği rivâyet ${ }^{136}$ ne Ebû Hafs Nesefî̀ de ne de Râzî'de bulunmaktadır, o rivâyeti Ebu'l-Leys es-Semerkandî'nin tefsirinde tespit ettik. ${ }^{137}$ Sonraki kısımlarda yine Ebû Hafs Nesefî’ den alıntılar yapmaktadır. ${ }^{138} \mathrm{Bu}$ kısımda Râzî’den istifade etmediği görülmektedir.

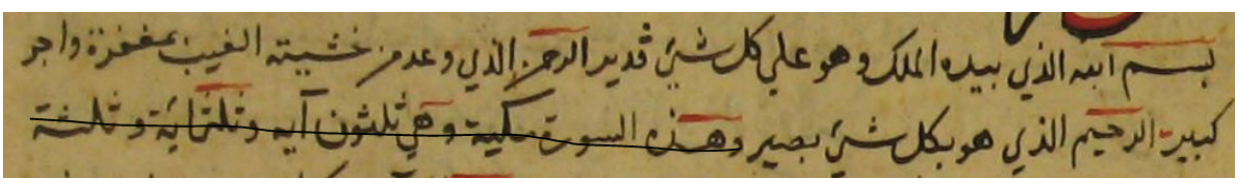

Resim 19. Aydinî, Mecma'u'l-envâr, 12: 55b.

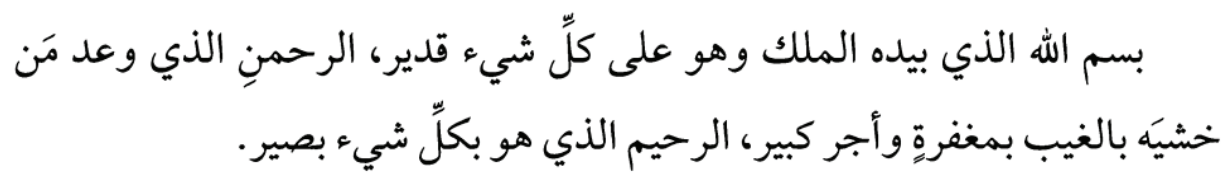

Resim 20. Ebû Hafs Nesefî, et-Teysîr fi't-tefsîr, 14: 501.

Yukarıda Aydınî ile Ebû Hafs Nesefî’nin Mülk sûresinin evvelindeki besmeleye yaptıkları tefsir verilmektedir. Görüldüğü gibi ikisi de aynıdır. Buna göre

133 Bk. Aydınî, Mecma 'u'l-Envâr, 12: 1a; en-Nesefî, et-Teysîr fi 't-Tefsîr, 14: 315.

134 Bk. Aydınî, Mecma 'u'l-Envâr, 12: 1a; en-Nesefî, et-Teysîr fi 't-Tefsîr, 14: 315-316.

135 Bk. Aydınî, Mecma 'u'l-Envâr, 12: 1a; en-Nesefî, et-Teysîr fi 't-Tefsîr, 14: 319.

136 Aydınî, Mecma'u'l-Envâr, 12: 1a.

137 Bk. Ebu'l-Leys es-Semerkandî, Tefsiru's-Semerkandî, 3: 332.

138 Bk. Aydınî, Mecma 'u'l-Envâr, 12: 1a; en-Nesefî, et-Teysîr fi 't-Tefsîr, 14: 319. 
Aydınî burada da tamamen Ebû Hafs Nesefî'den nakil yapmıştır. ${ }^{139}$ Sûrenin nerede indiği, âyet, kelime ve harf sayılarıyla münasebât konusunda verilen bilgiler de aynıyla Ebû Hafs Nesefî' den nakledilmiştir. ${ }^{140}$ Aydınî hem burada hem de diğer yerlerde Ebû Hafs Nesefî'nin sûrenin faziletine ve önemine dair verdiği bilgileri, sûrenin nerede nâzil olduğu ve kelime ve harflerinin sayısıyla ilgili bilgilerden sonra vermiştir. ${ }^{141}$ Yani Ebû Hafs Nesefî’nin tersini yapmıştır; Ebû Hafs Nesefî önce faziletini, sonra kelime ve harf sayılarını vermiş; Aydınî ise önce kelime ve harf sayılarını, sonra faziletine dair hadisleri zikretmiştir. Müellif sûrenin başında âyetlerin tefsirini yaparken birebir Ebu'l-Leys es-Semerkandî'nin tefsirinden alıntıda bulunmuştur. ${ }^{142}$ Sonra tekrar Ebû Hafs Nesefî' den nakil yapmış ve (الذي خلق الموت) (o ki ölümü yarattı) şeklindeki Mülk sûresi ikinci âyetin tefsirini olduğu gibi Ebû Hafs Nesefî' den almıştır. ${ }^{143}$ Burada müellifin Ebû Hafs Nesefî ile Semerkandî tefsirlerinden biraz ondan biraz bundan olacak şekilde müştereken yararlandığını, yaptığı tefsirin az bir kısmını ise Râzî'den aldığını görüyoruz. ${ }^{144}$ Müellif Aydınî (الذي خلق سبع سمو ات طباقا) (Yedi göğü/uçsuz bucaksız gökleri mükemmel bir uyum ve ahenk içinde yaratan O'dur) şeklindeki Mülk sûresi üçüncü ayetin tefsiriyle ilgili kısmı da Ebu'l-Leys es-Semerkandî ve Ebû Hafs Nesefî'den aynen alıntı yaparak tefsir etmiştir. ${ }^{145}$ Burada da yine Râzî’nin büyük oranda ihmal edildiği görülüyor.

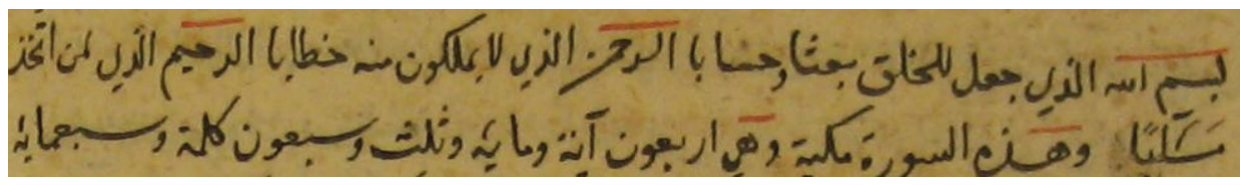

Resim 21. Aydınî, Mecma 'u'l-envâr, 12: 138a.

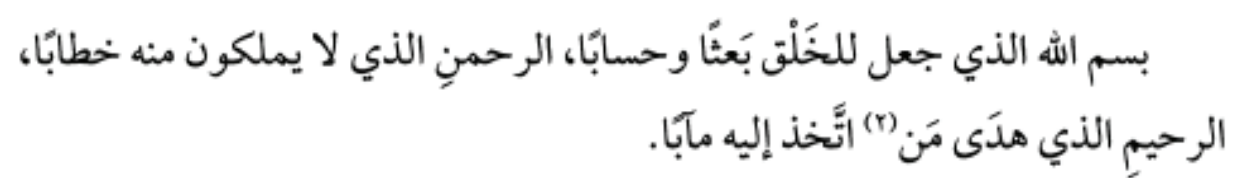

Resim 22. Ebû Hafs Nesefî, et-Teysîr fít-tefsîr, 15: 177.

139 Bk. Aydınî, Mecma'u'l-Envâr, 12: 55b; en-Nesefî, et-Teysîr fi 't-Tefsîr, 14: 501.

140 Bk. Aydınî, Mecma 'u'l-Envâr, 12: 55b; en-Nesefî, et-Teysîr fi't-Tefsîr, 14: 502-503.

141 Bk. Aydınî, Mecma 'u'l-Envâr, 12: 55b; en-Nesefî, et-Teysîr fi 't-Tefsîr, 14: 501-503.

142 Bk. Aydınî, Mecma'u'l-Envâr, 12: 55b; es-Semerkandî, Tefsiru's-Semerkandî, 3: 385-386.

143 Bk. Aydınî, Mecma 'u'l-Envâr, 12: 56a; en-Nesefî, et-Teysîr fi 't-Tefsîr, 14: 501-504.

144 Bk. Aydınî, Mecma 'u'l-Envâr, 12: 56a; er-Râzî, Mefâtîhu'l-Gayb, 30: 56.

145 Bk. Aydınî, Mecma'u'l-Envâr, 12: 56a; es-Semerkandî, Tefsiru's-Semerkandî, 3: 386; en-Nesefî, et-Teysîr fi't-Tefsîr, 14: 505. 
Nebe sûresinin başında da yine besmelenin Ebû Hafs Nesefî' den nakille tefsir edildiğini görüyoruz. ${ }^{146}$ Yukarıda Mülk sûresi için dediklerimiz burada da aynen geçerlidir ve kaynak Ebû Hafs Nesefî'dir. ${ }^{147}$ Âyetlerin tefsirinde de kaynak Semerkandî'dir. ${ }^{148}$

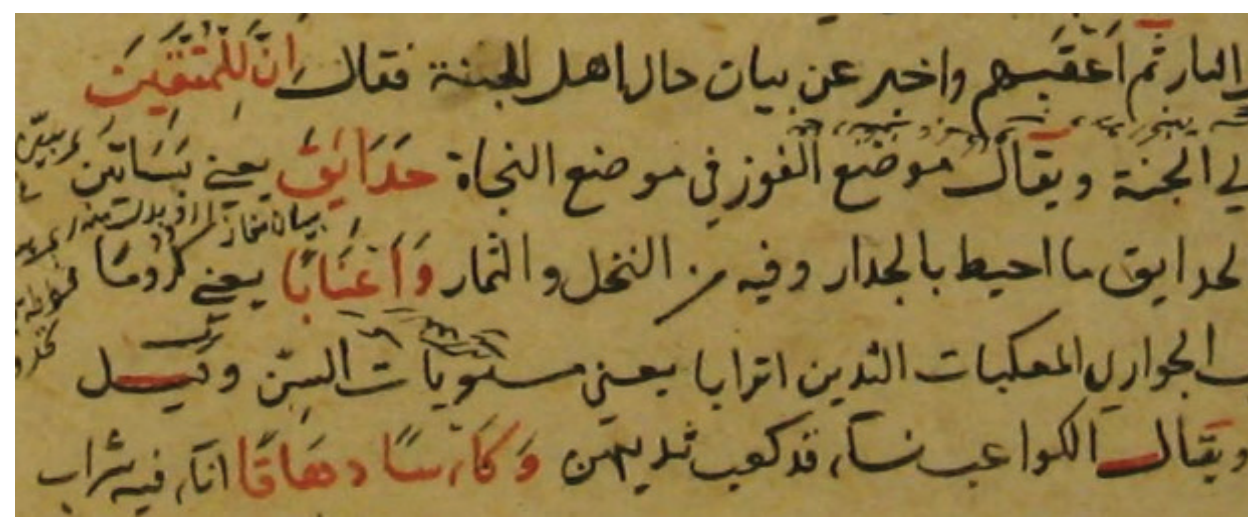

Resim 23. Aydınî, Mecma 'u'l-envâr, 12: 139a.

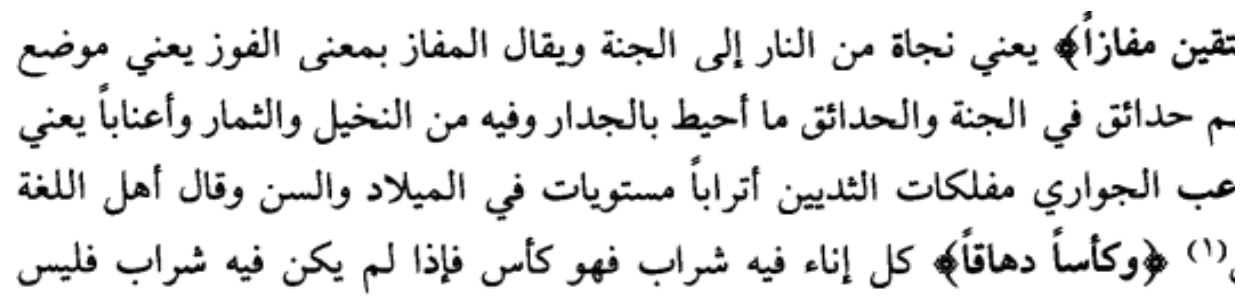

Resim 24. Es-Semerkandî, Tefsîru's-Semerkandî, 3: 440.

Nebe sûresinin 31-34. âyetlerinin tefsirinde de müellifin birebir Semerkandî’den yorumlar naklettiğini görüyoruz. ' ${ }^{\prime 2}$ Ancak Semerkandî’de (مفلكات) şeklindeki kelime, Aydınî’ de (المعكبات) şeklindedir. Bu, yazmadan kaynaklanan bir hata olabilir. Zira (عكب) kökünün konuyla bir alakası yoktur. Öte yandan Semerkandî, hurilerin yaşlarından bahsetmezken, Aydınî (ثلاث و ثلاثن) diyerek bunları otuz üç yaşında olacaklarını belirtmiştir. Geri kalan kısımlarda da kaynak Semerkandî’ dir. ${ }^{150}$

146 Bk. Aydınî, Mecma'u 'l-Envâr, 12: 138a; en-Nesefî, et-Teysîr fi 't-Tefsîr, 15: 177.

147 Bk. Hacı Paşa Aydınî Mecma’u'l-Envar, 12: 138a; en-Nesefî, et-Teysîr fi 't-Tefsîr, 15: 177.

148 Bk. Aydınî, Mecma'u'l-Envâr, 12: 138a; es-Semerkandî, Tefsiru's-Semerkandî, 3: 438.

149 Bk. Aydın̂̂, Mecma'u'l-Envâr, 12: 139a; es-Semerkandî, Tefsiru's-Semerkandî, 3: 440.

150 Bk. Aydınî, Mecma'u'l-Envâr, 12: 139a-140a; es-Semerkandî, Tefsiru's-Semerkandî, 3: 440441. 
Müellif, Mâ'ûn sûresinin başındaki besmelenin tefsirini yine aynen Ebû Hafs Nesefî'den alıntıyla verdikten sonra sûreyle ilgili bilgileri de olduğu gibi oradan almıştır. ${ }^{151}$ Âyetlerin manasını verirken ise Semerkandî’ den nakil yapmıştır. ${ }^{152}$

Aydınî Kur'ân'ın son üç sûresi olan İhlâs, Felak ve Nâs sûrelerinin başındaki besmelelerin tefsirini de aynen Ebû Hafs Nesefî' den alıntı yaparak vermiştir:

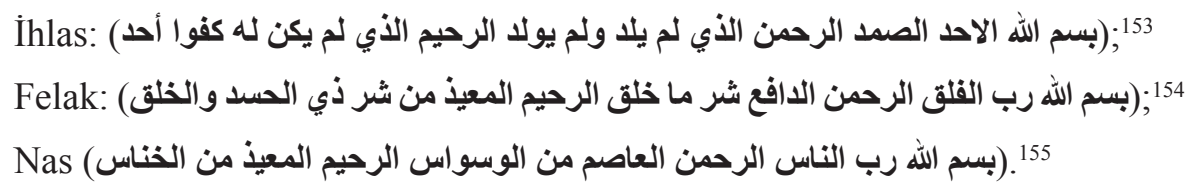

İhlas sûresinin baş kısmı aynen Ebû Hafs Nesefî’ den alınmadır. Daha sonraki kısımlar da büyük oranda bu tefsirden nakledilmiştir. ${ }^{156} \mathrm{Bu}$ arada Râzî'nin tefsirinde geçen uzunca malûmâttan da yararlandığını görüyoruz. ${ }^{157}$ Felak sûresinin de hem besmelesi, hem sûrenin baş kısmı aynen Ebû Hafs Nesefî’den alınmıştır. Sonra Ebû Hafs Nesefî' deki bazı rivâyetler atlanmış ardından tekrar nakle başlanmıştır. ${ }^{158} \mathrm{Bu}$ arada yaptığı uzun açıklamalarında Râzî’nin etkisini açıkça görmek mümkündür. ${ }^{159}$ Felak sûresi için zikrettiklerimiz neredeyse aynıyla Nâs sûresi için de geçerlidir. Ayrıca âyetlerin yorumunda daha ziyade Semerkandî’den nakiller görüyoruz. ${ }^{160}$ Geniş yorumlarda ise Râzî’nin etkisi mevcuttur. ${ }^{161}$

\section{Aydın̂̂’nin Tefsirdeki Yöntemi ve Muhtelif Konuları İşleme Tarzı}

Hacı Paşa Aydınî, tefsirinde diğer tefsirlerde olduğu gibi klasik diyebileceğimiz bir yöntemi takip etmiştir. ${ }^{162} \mathrm{Bu}$ cümleden olarak yer yer âyetleri başka

151 Bk. Aydınî, Mecma 'u'l-Envâr, 12: 250b; en-Nesefî, et-Teysîr fi 't-Tefsîr, 15: 497-498.

152 Bk. Aydınî, Mecma 'u'l-Envâr, 12: 250b; es-Semerkandî, Tefsiru's-Semerkandî, 3: 518.

153 Aydınî, Mecma'u'l-Envâr, 12: 274a; en-Nesefî, et-Teysîr fi 't-Tefsîr, 15: 529.

154 Aydınî, Mecma 'u'l-Envâr, 12: 278a; en-Nesefî, et-Teysîr fi 't-Tefsîr, 15: 543.

155 Aydınî, Mecma'u'l-Envâr, 12: 281a; en-Nesefî, et-Teysîr fi't-Tefsîr, 15: 551.

156 Bk. Aydınî, Mecma 'u'l-Envâr, 12: 274a-b; en-Nesefî, et-Teysîr fi 't-Tefsîr, 15: 529-541.

157 Bk. Aydınî, Mecma 'u'l-Envâr, 12: 274a-278a; er-Râzî, Mefâtîhu'l-Gayb, 32: 174-185.

158 Bk. Aydınî, Mecma 'u'l-Envâr, 12: 278b; en-Nesefî, et-Teysîr fi 't-Tefsîr, 15: 543-550.

159 Bk. Aydınî, Mecma 'u'l-Envâr, 12: 278b-281a; er-Râzî, Mefâtîhu'l-Gayb, 32: 186-195.

160 es-Semerkandî, Tefsiru's-Semerkandî, 3: 528-529.

161 Bk. Aydınî, Mecma 'u 'l-Envâr, 12: 281a-282b; en-Nesefî, et-Teysîr fi 't-Tefsîr, 15: 551-558; erRâzî, Mefâtîhu'l-Gayb, 32: 196-198.

162 Geniş bilgi için bk. Tawfik, "Hâcî Paşa el-Konevî ve Tefsîruhu Mecma'u'l-Envâr fî Cemî'i'l-Esrâr el-Mucelledu'l-Evvel Dirâse ve Tahkîk”, s. 42-89. 
âyetlerle tefsir etmiş, ${ }^{163}$ hadis ve sünnetle de izah ${ }^{164}$ yoluna gitmiştir. O da sahabe ve tâbiûn kavline başvurmuş, âlim ve fâzıl kişiler ile dinî konularda mütehassis olan daha başka zevâtın söz ve haberlerini de nakletmiştir. ${ }^{165}$ Müellif, önce sûrenin genel anlamına uygun bir şekilde besmeleyi tefsir etmiş, sonra nerede nâzil olduğunu, kaç âyet, kelime ve harften ibaret olduğunu belirtmiştir. Ardından sûrenin bir önceki sûreyle ve kendi içindeki intizam ve münasebetinden söz etmiştir. Son olarak faziletine dair bir hadis zikretmiş, akabinde âyetlerin yorumlanmasına geçmiştir. Örnek olması açısından burada Mücâdele sûresinin baş kısmını vermek istiyoruz:

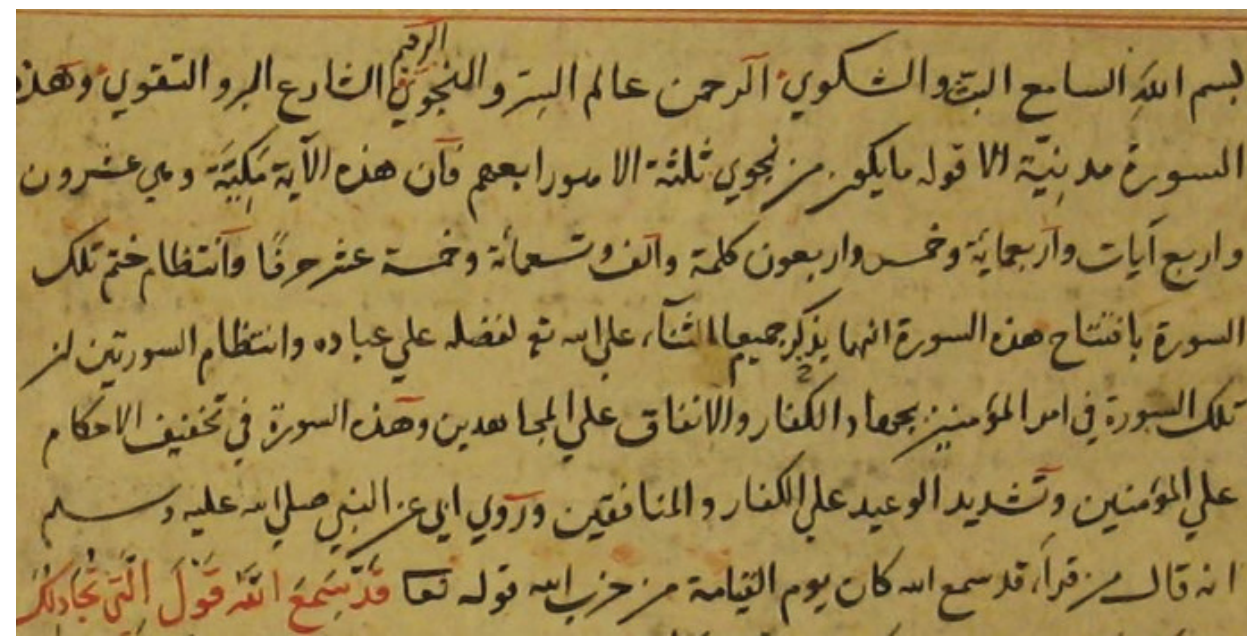

Resim 25. Aydınî, Mecma'u'l-envâr, 12: 1a.

Bu bilgileri ası1 kaynaklarından biri olan Ebû Hafs Nesefî̀ tefsiriyle karş1laştırarak Aydınî'nin Ebû Hafs Nesefî'den ne kadar istifade ettiğini, iki tefsir arasındaki ilişkinin derecesini göstermek istiyoruz. Bu açıdan Ebû Hafs Nesefî tefsirinden de aynı kısmı vermek istiyoruz:

163 Bk. Abay, "Osmanlı Dönemi Müfessirleri”, s. 19; Tawfik, "Hâcî Paşa el-Konevî ve Tefsîruhu Mecma'u'l-Envâr fî̀ Cemî'i’l-Esrâr el-Mucelledu'l-Evvel Dirâse ve Tahkîk”, s. 45-48; Babur, Hacı Paşa ve Mecma'u'l-Envâr fi Cemî'i'l-Esrâr Adlı Tefsirindeki Metodu, s. 38-53.

164 Bk. Tawfik, "Hâcî Paşa el-Konevî ve Tefsîruhu Mecma'u'l-Envâr fî Cemî'i'l-Esrâr el-Mucelledu'l-Evvel Dirâse ve Tahkîk”, s. 48-51; Babur, Hacı Paşa ve Mecma'u'l-Envâr fi Cemî'i'l-Esrâr Adlı Tefsirindeki Metodu, s. 54-67.

165 Geniş bilgi için bk. Tawfik, "Hâcî Paşa el-Konevî ve Tefsîruhu Mecma'u'l-Envâr fî Cemî'i'l-Esrâr el-Mucelledu'l-Evvel Dirâse ve Tahkîk", s. 44-54; Babur, Hacı Paşa ve Mecma'u'l-Envâr fi Cemî'i'l-Esrâr Adlı Tefsirindeki Metodu, s. 38-128. 
بسمِ الله سامعِ البثُّ والشَّكوى، الرَّحمنِ عالمِ السِّرٌ والنَّجوى، الرحيمِ شارعِ

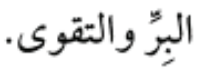

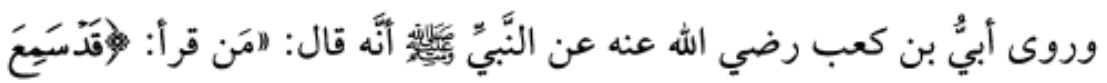

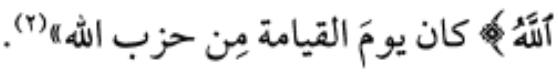

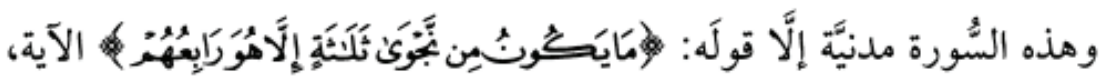
فإنَّ هذه الآية مكيَّة.

وهي عشرون آيةً وأربعُ آيات وأربع مئة وخمس وأربعون كلمة، وألفُ وتسعُ مئة وخمسة عشر حرفًا.

وانتظامُ ختمِ تلك السُّورة بافتتاح هذه السُورة: أنَّهما جميعًا بذكر الثَّناء على الله بفضله على عباده.

وانتظامُ السُو رتين: أنَّ تلك السُّورة في أمر المؤمنين بجهاد الكافرين، والإنفاقِ

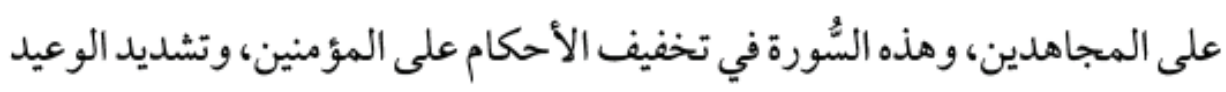

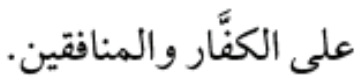

Resim 26. Ebû Hafs Nesefî, et-Teysîr fít-tefsîr, 14: 315-316.

Görüldüğü gibi bu iki metin arasında sûrenin faziletinden bahseden hadisin yerinin değişikliği dışında hiçbir fark yoktur. Buna göre Aydınî bu yöntemi aynen olduğu gibi Ebû Hafs Nesefî’ den almıştır diyebiliriz.

Müellif Fâtiha sûresinin faziletine dair de bir rivâyet nakletmiştir. Burada "şayet Fâtiha sûresi Tevrat'ta yer alsaydı, Mûsâ'nın kavmi Yahudi olmazdı" anlamına gelen uzunca bir hadis vermiştir. ${ }^{166}$ Abay, bu rivâyetin kaynaklarda geçmediğini belirtmiştir. ${ }^{167}$ Rivâyet aynen Ebû Hafs Nesefî'de de geçmektedir. ${ }^{168}$ Esasen Fâtiha'nın başından itibaren verilen bilgilerin hepsi birebir Ebû Hafs

166 Aydınî, Mecma'u'l-Envâr, 1: $18 \mathrm{~b}$.

167 Abay, "Osmanlı Dönemi Müfessirleri”, s. 23.

168 en-Nesefî, et-Teysîr fi 't-Tefsîr, 1: 97-88. 
Nesefî’ den alınmıştır. ${ }^{169}$ Fakat Ebû Hafs Nesefî' deki bazı bilgiler zaman zaman hazfedilmiştir, yine Ebû Hafs Nesefî’ deki Farsça metniler de alınmamıştır. Burada Râzî'den de istifade edilmiştir. Esasen Râzî ile Ebû Hafs Nesefî arasında da büyük bir benzerlik vardır. Buna göre Ebû Hafs Nesefî, aynı zamanda Râzî’nin de kaynaklarından biri olmalıdır.

Aydınî, bundan sonra âyeti rivâyet ve dirâyet yöntemiyle tefsir etmiş, sonra tasavvufî/işârî yönden izahını yapmıştır. Tefsirde bu şekilde bir başlıklandırma söz konusu değildir, ancak tefsir yöntemi bu şekildedir. Eseri tahkik eden Tawfik ise buna göre başlıklandırmalar yapmıştır. ${ }^{170}$ Müellif bütün bu konularda kendine has yeni bir görüş serdetmek yerine daha önceki tefsirlerden alıntı yapmakla yetinmiştir.

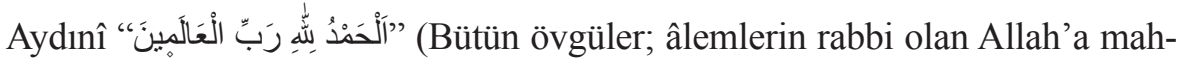
sustur) şeklindeki Fâtiha sûresi ikinci âyetini tefsir ederken âyette geçen (âlemîn) den kastın yer yüzünde debelenen ruh sahibi bütün varlıklar olduğunu belirtmiş, bu arada daha başka bazı görüşler de serdetmiştir. Ebû Hureyre'den nakille verdiği bu görüşlerden birine göre, Allah mahlûkâtı yaratırken onları melek, şeytan, cin ve insan olmak üzere dört sınıf olarak vücuda getirmiştir. Sonra bunları on parça yapmıştır; bu on parçanın dokuzunu melek, birini de şeytan, cin ve insan yapmıştır. Sonra bu bir parçayı on cüze ayırmıştır; bunların dokuzunu şeytan, birini cin ve insan kılmıştır. Sonra bu bir parçayı on kısma ayırmıştır; dokuzunu cin, birini de insan yapmıştır. Sonra insanları yüz yirmi beş guruba ayırmıştır; bunların yüz gurubunu Hindistan'a yerleştirmiştir. Bunlardan bir gurubunun adı Sâtûh'tur ki bunların başları köpeklerin başına benzemektedir. Diğer bir gurubun adı Mâlûh'tur, bunların gözleri göğüslerindedir. Diğer bir gurubun adı Mâsûh'tur, bunların kulakları fillerin kulağı gibidir. Başka bir gurubun adı Mâlûk'tur ki bunların ayakları onlara itaat etmeyen tuhaf bir yapıdadır. Bunların tamamı cehennemliktir. On iki gurubu Rum diyarına yerleştirmiştir. Bunlar Nastûrî, Milkâi ve İsrâilîlerdir. Bunların da tamamı cehenneme gidecektir. Altı gurubu Doğuya yerleştirmiştir. Bunlar Ye'cuc, Me'cuc, Hakan Türkleri (ترك خاقان), Halac Türkleri (ترك خلج), Hazar Türkleri (ترك خوخج) ve Kırgız(?) Türkleri (ترك خرخيز)dir. Bunların da hepsi cehennem ehlidir. Altı gurubu Mağrib bölgesine yerleştirmiştir; bunlar Zenc, Zent, Habeşe, Nûbe, Berber ve diğer kâfir Arap kabileleridir. Bunların da hepisinin gideceği yer cehennemdir. Geriye tevhid ehli bir tek gurup kalıyor ki bunları da Allah yetmiş üç firka yapmıştır. Bunların yetmiş ikisi tehlikededir, bunlar bidat ve dalâlet ehlidir. Geriye bir tek firka-i nâciye kalıyor ki onlar da Ehl-i sünnet ve'l-cemaattir. ${ }^{171}$ Hiçbir kaynakta

169 Aydınî, Mecma'u'l-Envâr, 1: 16b-49a. Krşl. en-Nesefî, et-Teysîr fi 't-Tefsîr, 1: 71-180.

170 Bir örnek için bk. Tawfik, "Hâcî Paşa el-Konevî ve Tefsîruhu Mecma'u'l-Envâr fî̀ Cemî'i'l-Esrâr el-Mucelledu'l-Evvel Dirâse ve Tahkîk”, s. 428-420.

171 Aydınî, Mecma'u'l-Envâr, 1: 25b. Nesefî’nin tefsirinden başka bir yerde rastlamadık. (en-Ne- 
bulamadığımız, ayrıca insanların atasının Âdem olduğu gerçeğiyle de bağdaştırılamayan bu uydurma rivâyeti Türk asıllı olan Ebû Hafs Nesefî’nin (v. 537/1143) herhangi bir yorum yapmadan vermesi, ${ }^{172}$ yine bir Türk âlim olan Aydınî’nin ondan aynen nakledip arkasından hiçbir yorum yapmaması son derece ilginçtir.

Aydını̂’nin tefsirinde Türklerle ilgili kısım şöyle geçiyor:

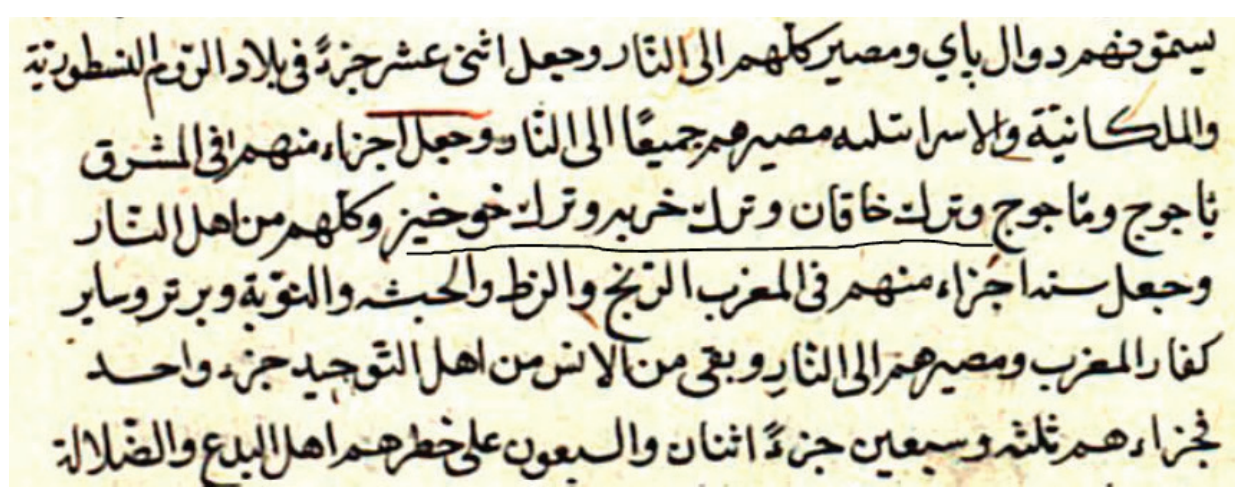

Resim 27. Hacı Paşa Aydınî, Mecma'u'l-envâr, 1: 25b.

Burada Hakan, Hirbe ve Havhiz şeklinde okuyabileceğimiz üç Türk kavminden bahsediliyor. Ancak bu kısım Ebû Hafs Nesefî’nin tefsirinin matbu nüshasında şöyle geçiyor: ${ }^{173}$

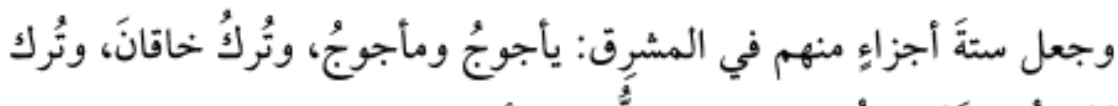

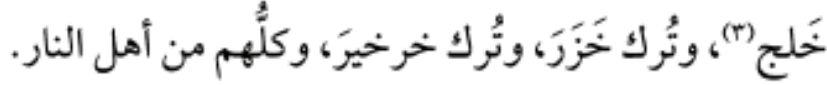

Resim 28. Ebû Hafs Nesefî, et-Teysîr fít-tefsîr, 1: 108

Burada da Hakan, Halac (veya Alac), Hazar ve Harhîr diye dört Türk kavminin adı geçiyor. Aydınî’nin eserinin bu cildini tahkik eden Ahmed Mahmoud, Ebû Hafs Nesefî'nin ibaresini esas almıştır. ${ }^{174}$ Ancak elimizde bulunan Ebû Hafs Nesefî’nin mahtût nüshasında ${ }^{175}$ şöyle bir durum vardır:

sefî, et-Teysîr fi t'-Tefsîr, 1: 107-108). Tercümeyi krş. Necmeddin Ömer en-Nesefî, et-Teysîr fi't-Tefsîr Ömer Nesefí Tefsiri, çev. Muhammed Coşkun, İstanbul, Türkiye Yazma Eserler Başkanlığı Yayınları, 2019, 1: 188.

172 en-Nesefî, et-Teysîr fi 't-Tefsîr, 1: 107-108.

173 en-Nesefî, et-Teysîr fi 't-Tefsîr, 1: 108.

174 Tawfik, "Hâcî Paşa el-Konevî ve Tefsîruhu Mecma'u'l-Envâr fî̀ Cemî'i'l-Esrâr el-Mucelledu'l-Evvel Dirâse ve Tahkîk", s. 153.

175 Bk. Ömer b. Muhammed en-Nesefî, et-Teysîr fi 't-Tefsîr, Câmiatu'l-Melik Suûd kısmu'l-mahtûtât, nr. 4923, 1: 18a. 


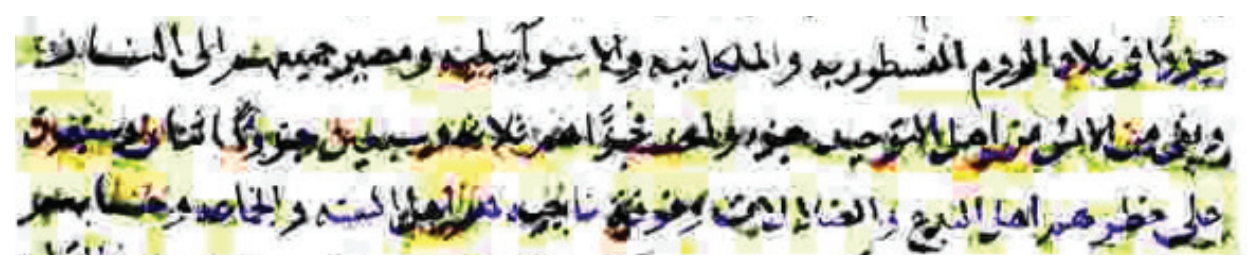

Resim 29. Ebû Hafs Nesefî, et-Teysîr fi 't-tefsîr, Câmiatu'l-Melik Suûd kısmu'l-mahtûtât, numara 4923, 1: 18a.

Burada Rum diyarında bulunan Nastûrî, Milkânî ve İsrâilîlerden bahsedildikten ve bunların tamamının cehennemlik olduğu belirtildikten sonra Türklerle ilgili kısım atlanmış ve yetmiş üç fırkayla ilgili kısma geçilmiştir. Acaba burada metne bir müdahale mi yapılmış? Bilemiyoruz. Muhtemelen başka nüshalardan istifadeyle tahkikli metin oluşturulmuştur. Nitekim elimizde bulunan ve İran'daki Kütüphâne-i Şûrây-i Meclis-i Millî’de bulunan 87113 numaradaki nüshada ifade şu şekilde geçmektedir:

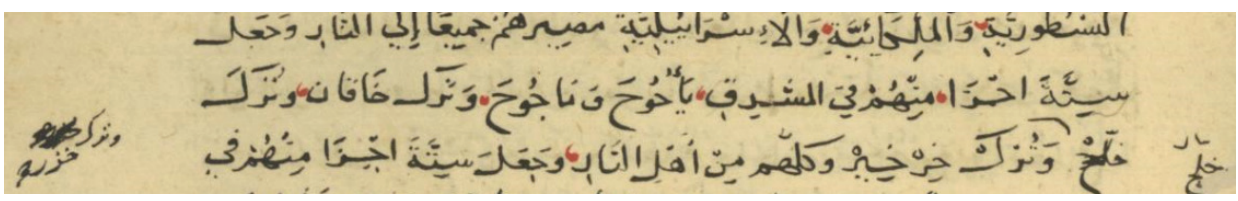

Resim 30. Ebû Hafs Nesefî, et-Teysîr fî̀t-tefsîr, (İran) Kütüphâne-i Şûrây-i Meclis-i Millî, no: 87713, 1: 27b

Burada sayfa kenarlarında yapılan tashihlerle açık bir şekilde (Türkü Hakan, Türkü Halec, Türkü Hazer ve Türkü Hirhîz) adında dört Türk kavminden basedilmektedir ve hepisinin cehennem ehli olduğu kaydedilmektedir. ${ }^{176}$ Öte yandan Ebussuûd Efendi (v. 982/1574) tefsirinde kaç tane âlemin olduğu ve bunların neler olduğu konusunda bazı rivâyetler verdiği halde Türklerle ilgili bu rivâyeti zikretmemiştir. ${ }^{177}$ Buna karşı1lık İsmail Hakkı Bursevî (v. 1137/1725) aynı rivâyeti zikretmiş, ancak orada da şöyle bir ifade kullanılmıştır:

176 Ebû Hafs Ömer en-Nesefî, et-Teysîr fî̀t-Tefsîr, (İran) Kütüphâne-i Şûrây-i Meclis-i Millî, nr: 87713, 1: $27 \mathrm{~b}$.

177 Ebu's-Suûd b. Muhammed el-İmâdî el-Hanefî, Tefsiru Ebî̀s-Suûd ev İrşâdu Akli s-Selîm ilâ Mezâya 'l-Kitâbi'-Kerîm, thk. Abdulkadir Ahmed Atâ, er-Riyâd, Mektebetu'r-Riyâd el-Hadîse, ts., $1: 21$. 


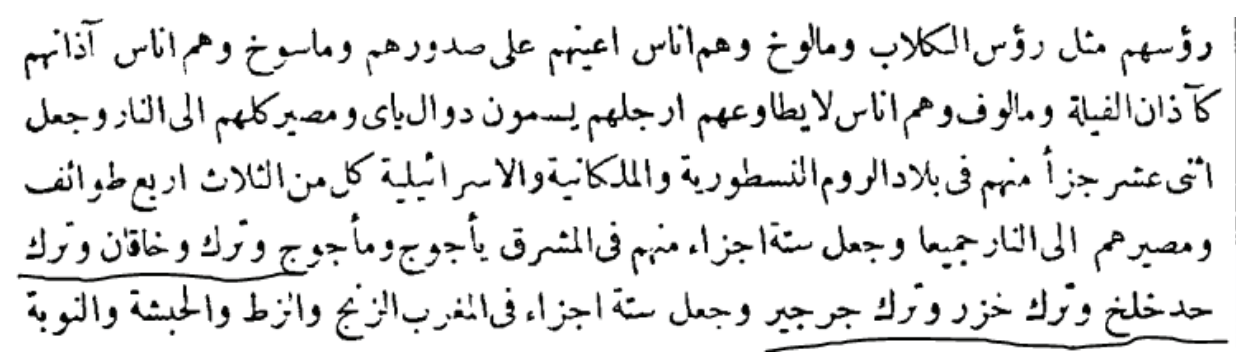

Resim 31. Bursevî, Rûhu'l-Beyân, 1: 13.

Görüldüğü gibi Bursevî, bütün guruplardan basederken onların cehennemlik olduğunu belirtttiği halde, Türklerin aralarında bulunduğu guruptan bahsederken cehenneme gideceklerine dair ifadeye yer vermemiştir. ${ }^{178}$ Acaba yazma nüshada vardı da matbu nüshada çıkarıldı mı? Elimizde mahtût nüshası olmadığı için mukayese yapma imkânımız olmamıştır. Türk kabilelerin adları verilirken de bazı farklilıklar söz konusudur.

Yukarıda geçe iki Türk müellifin Türklerle ilgili bilgilerin de bulunduğu bu asılsız rivâyeti Ebû Hureyre'ye isnatla Hz. Peygamber'in sözü gibi verip herhangi bir yorum yapmamaları ne kadar enteresan ise Ebû Hafs Nesefî'nin mahtût nüshalarının birinde bu kısmın atlanmış olması, Bursevî'nin içinde Türklerin bulunduğu kısımdan bahsederken cehennemlik olduklarını yazmaması da o kadar ilginçtir. Bu arada belirtelim ki, Cumhuriyet döneminde yazılan tefsirlerde böyle bir bilgiye rastlayamadik.

Râzî tefsirinde de bulamadığımız ${ }^{179}$ böyle bir rivâyet varsa bile burada sözü geçen Türklerin, İslamiyetten önceki dönemde yaşamış Türkler olduğunu hatırlatmış olalım.

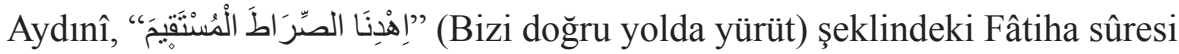
6. âyeti tefsir ederken, bazı genel açıklamalar yapmıştır. Sonra (واعلم) dedikten sonra (إن الصر اط المستقيم هو الدين القويم) diyerek doğru yolun, bu kuvvetli, sağlam din

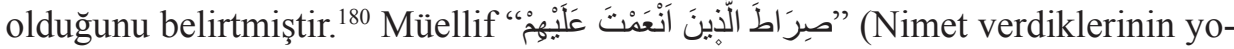
luna) şeklindeki Fâtiha sûresi yedinci âyette, nimet verildiği belirtilenlerle ilgili genel bilgiler vermiştir. Bunların nebiler, sıddikler, şehitler ve sâlihler olabileceğini belirttiği gibi, ârifler, râşitler, veliler ve ebrâr denen iyiliksever insanlar olduğunu da belirtmiştir. Âyette geçen nimetle ilgili olarak genel izahlar yapmıştır.

178 Bursevî, Rûhu'l-Beyân, 1: 13.

179 Er-Râzî, Mefâtîhu'l-Gayb, 1: 233-237.

180 Aydınî, Mecma'u 'l-Envâr, 1: 36a; en-Nesefî, et-Teysîr fi 't-Tefsîr, 1: 36a-37b. 
Buna göre fayda sağlayan her şey nimettir. Arkasından (واعلم) ifadesiyle bu âyette geçen nimetin, imân nimeti olduğunu söylemiştir. ${ }^{181}$

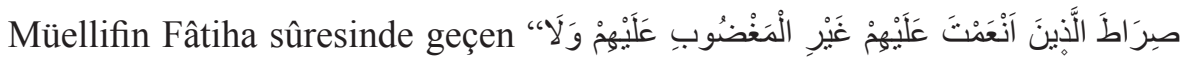
الضََّّلَّنَ "kendilerine imân ve hidâyette sebat lütfettiğin hayırlı kullarının yolunda yürüt. Senin gazabına uğrayanların, dalalete saplananların yollarına yöneltme bizi) $^{182}$ âyetini tefsir ederken, bunları, öteden beri açıklanageldiği üzere Yahudi ve Hristiyanlarla tefsir etmemesi dikkat çekicidir. Nitekim o, meşhur olan görüşe

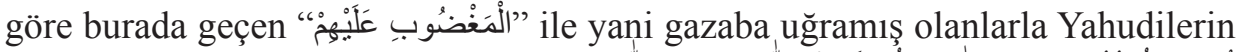

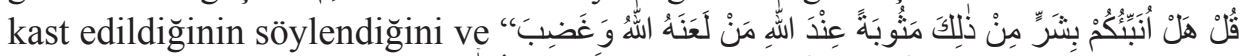

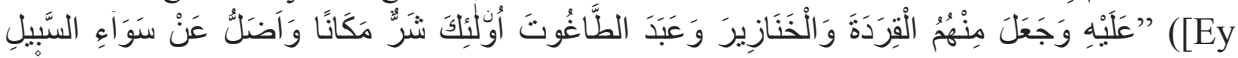
Peygamber!] Yine de ki onlara: "[Sizin iddianıza göre yanlış bir inanca sahip oluşumuzdan dolayı bizim Allah katındaki yerimiz çok kötü, cezamız da ağır olacaktır] . Ama isterseniz, Allah katında bize layık gördüğünüzden çok daha kötü konumda kimler olacak, şimdi ben size onu bildireyim: "Allah kimleri lanetlemiş ve kimlere gazap etmişse, kimleri [manevi ve ahlaki düşüklüğün bir göstergesi olarak adeta] maymuna ve domuza dönüştürmüşse ve yine kimler [buzağı heykeli gibi] putlara tanrılık yakıştırıp tapınmışsa, Allah katında durumu en kötü olan ve doğru yoldan büsbütün sapmış halde bulunan kimseler işte onlardır) ${ }^{183}$ âyetinin

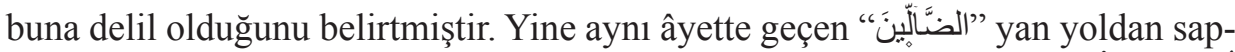

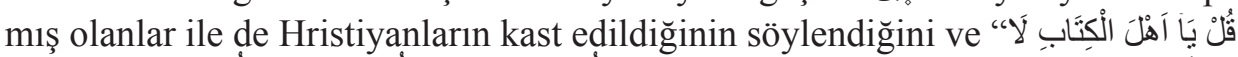

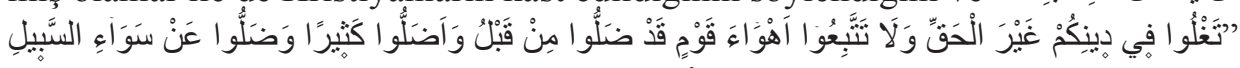
([Ey Peygamber!] De ki: “Ey Hıristiyanlar! [İsa'ya tanrılık yakıştırmak suretiyle] dininiz ve inanç sisteminizde haddi aşmayın. Daha önce doğru yoldan sapmış ve birçok insanı da saptırmış olan ve şimdi de doğru yoldan büsbütün uzaklaşmış hâlde bulunan birtakım insanların boş heveslerine, asılsız görüşlerine uymayın") ${ }^{184}$ âyetini buna delil göstermiştir. ${ }^{185}$ Sonra bu konuda şöyle bir değerlendirme yapmaktadır: Fakat bu görüş zayıftır, çünkü yaratıcıyı inkâr edenler bu iki din mensuplarından daha değersiz bir dindedirler. Onların dininden kaçmak daha evladır denilmiştir. En münasibi "gazaba uğrayanların" zâhir amellerde hata işleyen fâsıklar olması, "sapıtanların" da itikatta hata eden kişiler olmasıdır. Buna göre ilkini kâfirlere, ikincisini de münafiklara hamletmek daha uygundur. ${ }^{186}$ Tabii bu

181 Aydınî, Mecma'u'l-Envâr, 1: 38a; en-Nesefî̀, et-Teysîr fi 't-Tefsîr, 1: 37b-38b.

182 El-Fâtiha, $1 / 7$.

183 El-Mâide, 5/60.

184 El-Mâide, 5/77.

185 Abay, “Osmanlı Dönemi Müfessirleri”, s. 19.

186 Aydınî, Mecma'u'l-Envâr, 1: 38a. Ayrıca bk. Abay, “Osmanlı Dönemi Müfessirleri”, s. 19. 
konuda başka şeyler de söylenmiş̧ir. ${ }^{187}$ Müellif burada âyetin, üç gurup mükellef insanın olduğuna delalet ettiğini zikretmektedir. Birinci gurup, Allah'ın kendilerine nimet verdiği kimselerdir. İkinci gurup ehlu'l-maâsî dediğimiz günahkâr insanlardır. Üçüncü gurup ise ehlu'l-cehl denilen din konusunda bilgisi olmayan kimselerdir. ${ }^{188}$

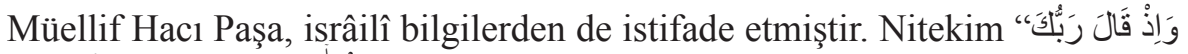

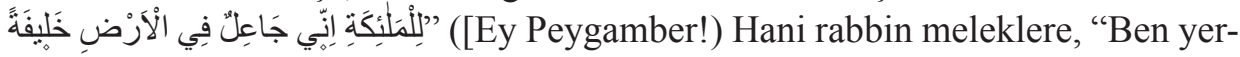
yüzünde bir halife (akıl ve irade sahibi bir varlık) yaratacağım" buyurdu) şeklindeki Bakara sûresi otuzuncu âyetini açıklarken kaynak göstermeden Âdem'in yaratılışı ile ilgili bazı isrâilî kıssalar nakletmiştir. ${ }^{189}$ Bazen kıssalar ve konular arasındaki münasebet üzerinde de durmuştur. Mesela yukarıda verdiğimiz âyeti ve sonrasında anlatılan Âdem'in yaratılışı ile ilgili kıssanın önceki âyetlerle ilişkisi hakkında şunları söylemiştir: Bu kıssanın öncekiyle irtibatı şudur: Orada kainatın yaratılışından bahsedildi, burada da beşerin ve onların başında Âdem'in yaratılışı anlatıld1. ${ }^{190}$

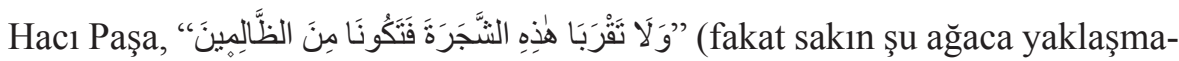
yın. Aksi takdirde kendinize yazık edersiniz) şeklindeki Bakara sûresi otuz beşinci âyeti tefsir ederken, âyette geçen ağacın ne ağacı olduğuyla ilgili İbn Abbas'tan bir rivâyet nakletmiştir. Buna göre bu ağaç buğday ve başağıdır. Sonra Hz. Ebû Bekir'in de bunu Hz. Peygamber'e sorduğu ve onun da bu ağacın mübarek sünbül ağac1 olduğunu söylediğini kaydetmiştir. "فيه: (Ne var ki şeytan [yasak ağacın meyvesinden yemelerini sağlayarak] Âdem'i ve eşini yanılttı. Böylece onların meşakkatsiz/sıkıntısız yaşantılarının son bulmasına sebep oldu) şeklindeki Bakara sûresi otuz altıncı âyetini tefsir ederken de şeytanın cennete girerek Âdem ile Havva'yı kandırması ve onların cennetten çıkarılmasına sebeb olması yönünde Kelbî kanalıyla bazı isrâilî haberler aktarmış, rivâyet haklarında herhangi bir değerlendirme yapmamıştır. ${ }^{192}$ Râzî de benzer bilgiler vermiş ancak akabinde haberi tenkit etmiştir. ${ }^{193}$

187 Aydınî, Mecma'u'l-Envâr, 1: 39a.

188 Aydınî, Mecma'u'l-Envâr, 1: 39a.

189 Bk. Abay, “Osmanlı Dönemi Müfessirleri”, s. 22.

190 Aydınî, Mecma'u'l-Envâr, 1: 98a. Ayrıca bk. Abay, "Osmanlı Dönemi Müfessirleri”, s. 24.

191 Aydınî, Mecma 'u'l-Envâr, 1: 120a. Krş. er-Râzî, Mefâtîhu'l-gayb, 3: 6. Ayrıca bk. Abay, "Osmanlı Dönemi Müfessirleri”, s. 19.

192 Aydınî, Mecma'u'l-Envâr, 1: 120b-121a.

193 er-Râzî, Mefâtîhu'l-Gayb, 3: 16. 


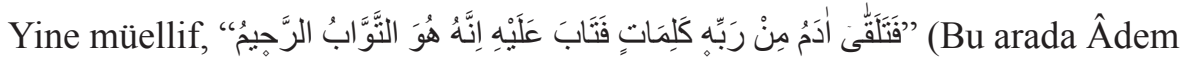
Rabbinden bazı kelimeler öğrendi ve onlarla af diledi. Allah da onun tövbesini kabul buyurdu. Çünkü Allah samimi tövbeleri daima kabul buyuran, rahmet ve merhameti sınırsız olandır) ${ }^{194}$ şeklindeki Bakara sûresi otuz yedinci âyeti tefsir ederken, Âdem'in Rabbinden aldığ 1 kelimelerin neler olduğu hususunda müfessirlerin görüşlerine yer vermiştir. Buna göre bu kelimeler Muhammed'e (a.s.) salat okumak ve onun şefaatini dilemektir. Âdem, "Muhammed" ismini anarak Allah'tan şefaat dilemiş ve onun sebebiyle bağışlanmıştır. ${ }^{195}$ Bu rivâyet bazı âlimler tarafından eleştirilmiştir. ${ }^{196}$

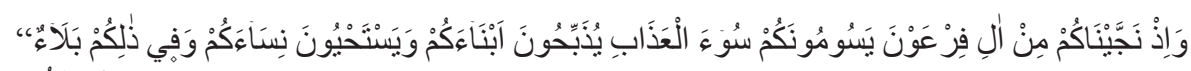

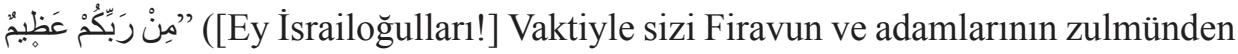
kurtarmıştık. Onlar size işkencenin en beterini reva görüyor, oğullarınızı katledip sağ bıraktıkları kızlarınızı/kadınlarınızı kötü amaçları için kullanıyorlardı. Bu zulümden kurtulmanız, rabbinizin size lütfettiği çok büyük bir nimetti) şeklindeki Bakara sûresi kırk dokuzuncu âyetin tefsirinde ayette geçen "bela" kelimesinin "ibtila"dan geldiğini ve imtihan manasında olduğunu nakletmektedir. Ona göre bela, hem nimete, hem de şiddetli mihnete denir. Ama genellikle hayır ve şer için kullanılır. ${ }^{197} \mathrm{Bu}$ ifadeler aynen Râzî'nin tefsirinde de geçmektedir. ${ }^{198}$ Yine

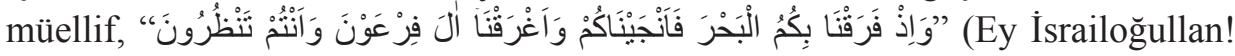
Hani biz vaktiyle sizin için denizi yarmış ve böylece sizi düşmandan kurtarmış, Firavun ve adamlarını ise gözünüzün önünde sulara gömmüştük) şeklindeki âyeti (Hatırlayın size olan nimetimi! Sizin için Nil denizini on ikiye bölmüştüm ve

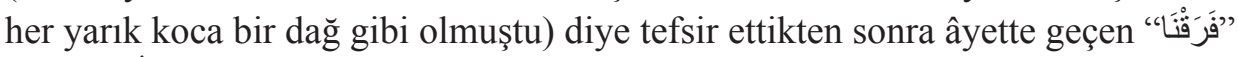

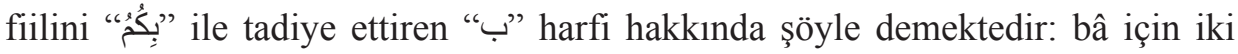
vecih vardır; ilki "lâm" manasına olup "sizin için ayırdı" demektir. Bu tarzda kullanıldığı âyetler vardır. İkincisi, "sizin girmeniz için ayırdı" şeklinde olup, "bâ" hakikî anlamındadır. ${ }^{199}$

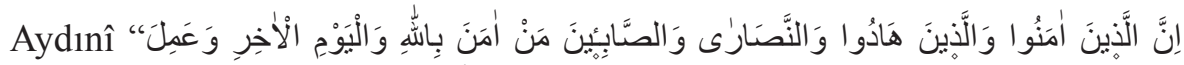

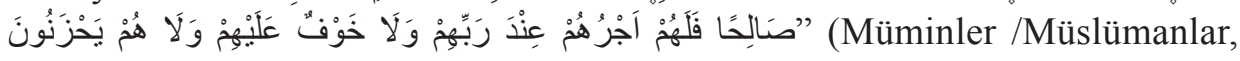
Yahudiler, Hıristiyanlar, Sâbiîler ... İşte bütün bu farklı dini kimliklere sahip olanlardan kim Allah'a ve kıyamet-hesap gününe imân edip imânına yaraşır

194 El-Bakara, 2/37.

195 Aydınî, Mecma'u'l-Envâr, 1: 125a-b. Ayrıca bk. Abay, “Osmanlı Dönemi Müfessirleri”, s. 20. 196 Bk. Abay, "Osmanlı Dönemi Müfessirleri”, s. 20.

197 Aydınî, Mecma 'u'l-Envâr, 1: 138a. Ayrıca bk. Abay, “Osmanlı Dönemi Müfessirleri”, s. 24.

198 er-Râzî, Mefâtîhu'l-Gayb, 3: 74. Bk. Abay, “Osmanlı Dönemi Müfessirleri”, s. 24.

199 Aydınî, Mecma 'u'l-Envâr, 1: 138b. Ayrıca bk. Abay, “Osmanlı Dönemi Müfessirleri”, s. 24. 
güzellikte işler yaparsa hak ettiği mükâfatı rabbinden alacaktır. Üstelik böyleleri için ne ahirette azap korkusu ne de dünyada bırakılan güzel şeyler adına hüzün söz konusu olacaktır) şeklindeki Bakara sûresi altmış ikinci âyetini açıklarken burada adı geçen gurupların Yahudiler, Hristiyanlar ve Sâbiîler olduğunu belirttikten sonra, bunlardan kim Allah'a inanır, ahiretin vuku bulacağına imân eder ve sâih amel işlerse, onların bu imân ve amellerinin karşılığını alacakların1 söylemektedir. Sonra (قيل) sigasıyla burada sözü geçen Yahudilerin, Hz. Mûsâ zamanında yaşayıp ona imân eden ve bu imân üzere ölenler olduğunun; Hıristiyanlarında Hz. Îsâ zamanında yaşayıp ona imân eden ve bu imân üzere ölenler olduğunun, Sâbiîlerin de Hz. Peygamber'den çok önceki dönemlerde kendilerine gelen peygamberlere imân edip bu imân üzere ölenler olduğunun söylendiğini yazıyor. ${ }^{200}$ Ayrıca burada Kuşeyrî’ den de ismini vererek şu alıntıyı yapmaktadır: "Diliyle imân ettiğini söyleyip fakat kalpten imân etmemiş olan münafiklar, Yahudiler, Hıristiyanlar ve Sâbiîler, bunlardan kim Allah'a halisâne bir şekilde ve sıhhatının şartlarına göre imân ederse ona ecir vardır ve o korkmayacak, mahzun da olmayacaktır". ${ }^{201}$

Letâifu'l-işârât'ta Kuşeyrî (v. 465/1072) şöyle demiştir: “Asıl bir olduktan sonra yolun farklı olması hüsn-i kabûle mani teşkil etmez; kim Allah Teâlâ'yı âyet ve mucizelerinde belirtildiği şekliyle tasdik eder ve hakikatı ve sıfatları konusunda haber verdiklerine imân ederse, şeriatinin farklı olması ve mensup olduğu dininin isminin farklı olması, ilâhî rızayı kazanmaya engel teşkil etmez. Bundan dolayı Allah şöyle demiştir: 'İman edenler, Yahudiler...bunlardan kim imân ederse', yani şayet bunlar Allah'ı bilme ve tanıma konusunda ittifak ederslerse hepsine güzel akıbet ve bol sevap vardır". ${ }^{202}$

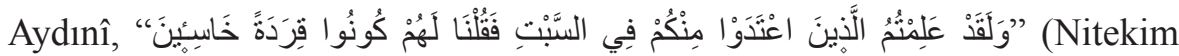
siz [Davud peygamber zamanında] cumartesi gününün kutsallığını ihlal edip o gün avlanma yasağını çiğneyenlerin bulunduğunu bilirsiniz. Bu azgınlıkları sebebiyle biz de onlara, "Hepiniz aşağıllık bir halde maymunlar olun/maymunlar gibi olun. [Bundan böyle zillet, rezillik, sefillik içinde yaşayın]" dedik) şeklindeki Bakara sûresi altmış beşinci âyetini verirken, Mûsâ Peygamber'in Yahudiler için ibadet günü olarak Cuma gününü seçtiğini, fakat onların daha sonra bunu

200 Tawfik, "Hâcî Paşa el-Konevî ve Tefsîruhu Mecma'u'l-Envâr fî̀ Cemî'i'l-Esrâr el-Mucelledu'l-Evvel Dirâse ve Tahkîk", s. 418.

201 Tawfik, "Hâcî Paşa el-Konevî ve Tefsîruhu Mecma'u'l-Envâr fî̀ Cemî'i'l-Esrâr el-Mucelledu'l-Evvel Dirâse ve Tahkîk", s. 418.

202 Ebu'l-Kasım Abdülkerim b. Hevâzin el-Kuşeyrî, Tefsîru'l-Kuşerî el-Musemmâ Letâifu'l-İşârât, nşr. Abdullatif Hasan Abdurrahman, Beyrût, Dâru'l-Kutubi'l-İlmiyye, 2007/1428, 1: 50 . 
Cumartesiyle değiştirdiklerini belirtmiştir. Sonra bunlar Cumartesi günü avlanma yasağını çiğneyince ve kendilerini bu konuda uyaranları dinlemeyince Allah onları maymuna dönüştürdü. Üç gün maymun olarak kaldılar, daha sonra Allah hepsini helâk etti. Bunlardan geriye hiçbir şey kalmadı. Müellif, burada Mücâhid'in bedenlerinin değil, kalplerinin maymunlaştığını söylediğini de nakletmiştir. Müellif, daha başka bazı görüşler de vermiştir. ${ }^{203}$

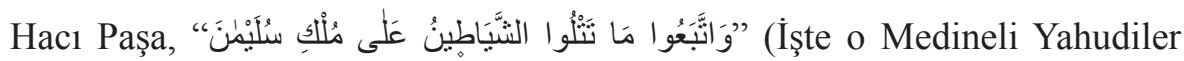
[Peygamberse komplo kurma, onun risalesine ve tevhid davetine engel olma hususunda] şeytan tabiatlı kimselerin vaktiyle Süleyman'ın yönetimi aleyhinde takip ettikleri yöntemleri/taktikleri izlemekteler) şeklindeki Bakara sûresi yüz ikinci âyetini açılarken, âyetin nüzûl sebebi bağlamında naklettiği rivâyetelerde Yahudilerin Süleyman'a sihir isnad ettiklerini belirtmiştir. Sahabeye dayanmayan, dolayısıyla sahih olmaları mümkün olmayan bu rivâyetlerle ilgili herhangi bir tenkit yapmamıştır. ${ }^{204}$

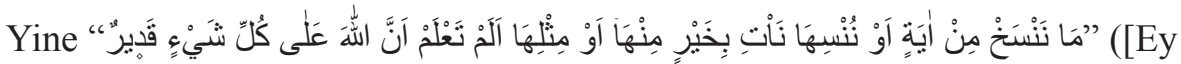
Peygamber!) Biz bir âyeti değiştirmek veya unutturmak istediğimizde/bir şeriatı kısmen değiştirmek veya onu tamamen kaldırmak istediğimizde, onun yerine daha mükemmelini veya en azından onu aratmayacak olanını getiririz. Bilirsin ki Allah her şeye kadirdir) şeklindeki Bakara sûresinin yüz altıncı âyetini tefsir ederken öncelikle kelimelerin aslî manası ve farklı kıraatlere göre okunma biçimleri ve bunalara göre ortaya çıkan manalar hakkında bilgi vermektedir. Sonra Yahudilerin konuyla ilgili düşüncesinden, Hz. Peygamber döneminde nesih ile alakalı meydana gelen bazı gelişmelerden bahsetmektedir. Ardından nesih ve çeşitleri konusunda uzun bilgiler vermektedir. Ayrıca tasavvuf anlayışında neshin ne anlama geldiğini de açıklamaktadır. ${ }^{205}$ Bütün bunlardan müellifin Kur'ân'da neshin vukuûna inandığı sonucu çıkmaktadır.

Müellife göre Kur'ân hem bâtın ehline, hem de zâhir ehline inmiştir; Kur'ân'ın hem bâtınî, hem de zâhirî yanı vardır; Kur'ân'ın zâhir hükümlerinde nesih söz konusu olabilir, ancak bâtın hükümleriyle ilgili asla herhangi bir nesih mevzubahis olamaz. ${ }^{206}$ Buna benzer bir durum Bursevî’nin tefsirinde de tekrarlanmıştır. ${ }^{207}$

203 Tawfik, "Hâcî Paşa el-Konevî ve Tefsîruhu Mecma'u'l-Envâr fî̀ Cemî'i'l-Esrâr el-Mucelledu'l-Evvel Dirâse ve Tahkîk", s. 423.

204 Bk. Abay, "Osmanlı Dönemi Müfessirleri”, s. 20.

205 Tawfik, "Hâcî Paşa el-Konevî ve Tefsîruhu Mecma’u'l-Envâr fî Cemî'i'l-Esrâr el-Mucelledu'l-Evvel Dirâse ve Tahkîk", s. 473-477.

206 Aydınî, Mecma'u'l-Envâr, 1: 236a. Ayrıca bk. Abay, “Osmanlı Dönemi Müfessirleri”, s. 21.

207 Bk. Bursevî, Rûhu'l-Beyân, 1: 289. 
Bursevî bunun et-Te 'vîlâtu'n-Necmiyye' de de geçtiğini belirtmiştir. ${ }^{208}$ Ama Bursevî'nin zikrettiklerine benzer ifadelere et-Te'vîlât'ta rastlamadık. ${ }^{209}$

Müelif, ahkam âyetlerini hem zâhir hem de işârî cihetiyle tefsir etmiştir. Zâhir yönüyle anlatılan hususlar ya birebir ya da özetlenerek Râzî'nin tefsirinden alınmıştır. Mesela kıblenin tahviliyle ilgili Bakara sûresi yüz kırk dördüncü âyetin tefsirinde yüzü Mescid-i Haram'a döndürme emrinin, bütün bedeni kıbleye çevirmek manasına geldiğini belirtmiştir. Daha sonra Mescid-i Haram'ın neresi olduğu konusundaki görüşleri ve buna dair delilleri zikretmiştir. Ardından "mes'ele" başlığı altında kıbleye dönme konusunda mezhep imamlarının görüşeri üzerinde durmuştur. ${ }^{210} \mathrm{Bu}$ hususta anlatılanların tamamı Râzî’nin tefsirinden alınmıştır. ${ }^{211}$ Ne var ki Hacı Paşa, Râzî’nin "bahis” dediğine “mes'ele" demiştir. ${ }^{212}$ Âyetin işârî tefsir yönünden izahlarını da vermiş, ${ }^{213}$ ancak bunlar da Kâşânî’nin tefsirinden alınmıştır. ${ }^{214}$

Tefsirde ele alınan kelâmî konular da Râzî'nin tefsirinden nakledilmiştir. Mesela Bakara sûresi otuz altıncı âyetin açıklaması yapılırken Âdem ve Havva'nın şeytan tarafından aldatılıp cennetten çıkarılması anlatılmaktadır. Bu husus peygamberin ismet sıfatına müteallık bir konudur. $\mathrm{O}$ da peygamberlerin ismet sıfatına taalluk eden bu hususta âlimlerin görüşlerini serdettikten sonra peygamberlerin, peygamber olmadan önce de masum olup olmadıkları konusunu ele almıştır. Burada muhtelif görüşler ve bunlara dair deliller verildikten sonra Ehl-i sünnetin görüşü olan husus tercih edilmiştir. Buna göre Âdem'den hiçbir zaman küçük veya büyük günah sâdır olmamıştır. ${ }^{215}$ Bütün bunlar ve yapılan tercih aynen Râzî’nin tefsirinden nakledilmiştir. ${ }^{216}$

Keza müellif, Safa ile Merve'nin hac ve umre sirasinda sa'yedilmesinden

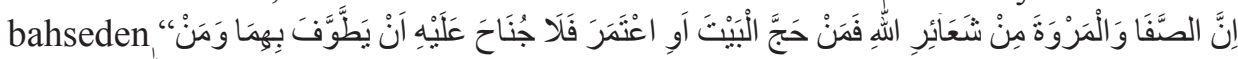

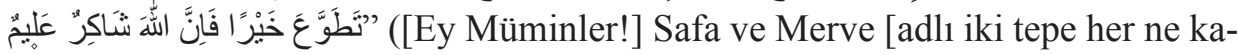
dar İslam öncesi dönemlerde İsaf ve Naile adlı putların bulunduğu mekânlar olsa da sonuçta] Allah'ın değer atfettiği birer nişane, birer semboldür. Bu yüzden, hac

208 Bursevî, Rûhu'l-Beyân, 1: 289.

209 Bk. el-Kübrâ, et-Te'vîlatu'n-Necmiyye, 1: 196-197.

210 Aydinî, Mecma'u'l-Envâr, 1: 201b-202b.

211 Bk. er-Râzî, Mefâtîhu'l-Gayb, 4: 123-135. Ayrıca bk. Abay, “Osmanlı Dönemi Müfessirleri”, s. 22.

212 Abay, "Osmanlı Dönemi Müfessirleri”, s. 23.

213 Aydınî, Mecma'u'l-Envâr, 1: 203a-b.

214 Abay, "Osmanlı Dönemi Müfessirleri”, s. 23.

215 Aydınî, Mecma'u'l-Envâr, 1: 123a-b.

216 Abay, "Osmanlı Dönemi Müfessirleri”, s. 23. 
veya umre yapan kişinin bu iki tepe arasında [ibadet maksadıyla] hızlıca gidip gelmesinde sakınca yoktur. Her kim ihlas ve samimiyetle bir iyilik/ibadet yaparsa Allah katında bunun mükâfatını görür. Çünkü Allah iyilikleri fazlasıyla mükâfatlandırır; yaptığınız her iyiliği bilir) şeklindeki Bakara sûresi yüz elli sekizinci âyetini şu şekilde tefsir etmiştir: Burada zâhir olan şiarlar bâtın olan şiarlar üzerine bina edilmiştir. Yani Safa ve Merve hem zâhirde, hem bâtında şiardırlar. Safa sır, Merve ruhtur. Hak yolunun yolcusu olan kişi (sâlik) ikisi arasında sa'yeder. Kevneynle alakasını keserek, sekaleynden siyrılarak sır safasını sa'yeder, bazen de ruh mervesinde sa'yeder. O hayırları, dâhilî-hâricî, bâtınî-zâhirî bütün insânî cüzlere ulaştırmaktadır. Bunu da itaatte ve kendine, ehline, iyâline ve tüm âleme hayırları takdim etmede bâtınî ve zâhirî halleri gözeterek yapmaktadır. ${ }^{217}$

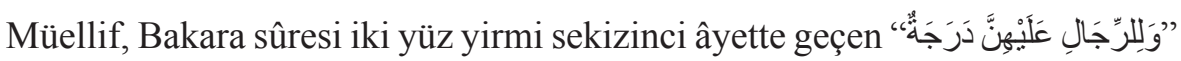
(Ancak kocalar için (eşlerinden) bir derece daha üstünlük söz konusudur) cümlesini, boşama yetkisinin kendilerinde olması, eşlerinin geçimini kendilerinin sağlıyor olması ve bu hususta kendilerinin sorumlu olması, kadınların velâyetinin kendilerinde olması gibi hususlar sebebiyle erkeklerin bir derece kadınlardan üstün olduğunu izah etmektedir. ${ }^{218}$

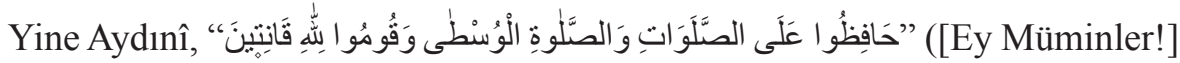
Namazlara, özellikle orta namaza [sabah veya ikindi namazına] devam edin ve namazlarınızı Allah için bütün samimiyetinizle k1lın) şeklindeki Bakara sûresi iki yüz otuz sekizinci âyette geçen "orta namaz"dan kastın hangi namaz olabileceği konusunda muhtelif rivâyetler vermektedir. Buna göre bu namaz, sabah, öğle, ikindi, akşam veya yatsı olabilir. Kendisi bu konuda herhangi bir tercihte bulunmamamktadır. Ayrıca âyette bu hususun belirtilmemiş olmasının hikmetine değinmektedir. Müellif burada "orta" kelimesinin gelmiş olmasının Arapça bakımından namaz vakitlerinin beş olduğunu gösterdiğini de yazıyor. Ayrıca her bir vakit namazın fazileti hakkında da uzun açıklamalar yapımaktadır. ${ }^{219}$

Müellif Aydınî, yüz yıl ölü kaldıktan sonra diriltilen kişinin anlatıldığı Bakara sûresi iki yüz elli dokuzuncu âyette söz konusu edilenin Üzeyir olduğuna dair kıssayı uzun uzun anlatmaktadır. ${ }^{220}$

217 Aydınî, Mecma 'u'l-Envâr, 1: 216a. Ayrıca bk. Abay, “Osmanlı Dönemi Müfessirleri”, s. 25.

218 Bk. Tawfik, "Hâcî Paşa el-Konevî ve Tefsîruhu Mecma'u'l-Envâr fî̀ Cemî'i’l-Esrâr el-Mucelledu'l-Evvel Dirâse ve Tahkîk", s. 683.

219 Bk. Tawfik, "Hâcî Paşa el-Konevî ve Tefsîruhu Mecma'u'l-Envâr fî̀ Cemî'i'l-Esrâr el-Mucelledu'l-Evvel Dirâse ve Tahkîk", s. 697-700.

220 Bk. Tawfik, Hâcî Paşa Tefsîruhu Mecma'u'l-Envâr fî Cemî'i'l-Esrâr el-Mucelledu'l-Evvel Dirâse ve Tahkîk, s. 743-745. 


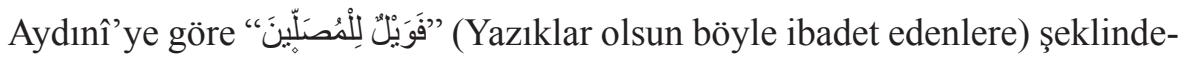
ki Mâûn sûresi dördüncü âyette sözü edilenlerden maksat münafiklardır. ${ }^{221}$

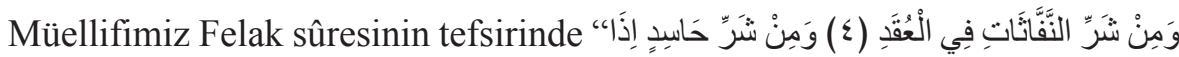
"حَسَدَ (Düğümlere üfleyen büyücülerin, kıskandığg zaman hasetçinin şerrinden o yüce rabbe sığınırım ben!) şeklindeki Felak sûresi dört ve beşinci âyetleri açıklarken sihir ve haset yapandan muradın Lebid b. el-A'sam ve onun Hz. Peygamber'e yaptığı sihir olduğunu belirtmektedir ve Hz. Peygambere sihrin nasıl yapıldığını, iki meleğin gelerek Hz. Peygamber'e bunu haber vermelerini, sihrin hakikatini, buna dair tarışmaları detaylı bir şekilde anlatmaktadır. ${ }^{222}$

\section{Tıp Alanıyla İlişkilendirilebilecek Âyetleri Tefsiri}

Normalde tıp alanında önemli bir âlim olması hasebiyle Aydınî'nin bu alanla ilgili âyetleri daha geniş ve orijinal ifadelerle tefsir etmesi beklenir. Ancak müel-

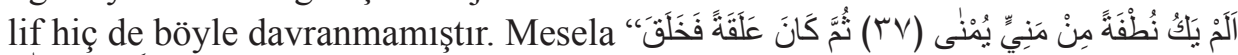
"فَسَوُّى (r) (O, vakti zamanında ana rahmine dökülmüş bir damlacık meniden ibaret değil miydi?! 38. Sonra kan pıhtısı hâline geldi; [ardından bir çiğnemlik ete dönüştü]; nihayet Allah onu tüm uzuvları yerli yerinde bir insan hâline getirdi. 39. Yine Allah ondan/meniden iki cinsi, erkek ve dişiyi meydana getirdi) şeklindeki Kıyâme sûresi 37-39. âyetlerin tefsirinde bir tabipten beklenen herhangi bir açıklama yapmamıştır. ${ }^{223}$ Tamamıyla Râzî’nin tefsirinden ufak bazı ihtisarlarla alıntılar yapmakla yetinmiştir. Buna göre bu âyet haşrin sıhhati konusunda delil olarak kullanılmıştır. Âyette geçen nutfe ile insanın, babasının sulbundan anasının rahmine dökülen bir sudan geldiğine, necâsetin çıkış mahalli demek olan bir kanaldan sudûr eden bir meniden yaratıldığına işaretle o kimsenin halinin önemsizliği belirtilmiş, böyle olan bir varlığın Allah'a itaatten yüz çevirmesinin, Rabbine karşı büyüklenmesinin uygun düşmediği ifade edil-

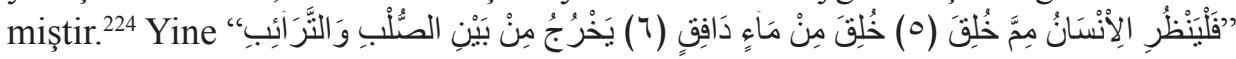
([Ölümden sonra dirilişe yalan diyen] insan neden yaratıldığına bir baksa ya! 6-7. İşte o [anne rahmine atılan,] bel ve göğüs arasından çıkan bir [damlacık] sudan yaratıldı) şeklindeki Târık sûresi 5-7. âyetleri tefsir ederken de diğer tefsirlerde bulunanlardan farkl1 bir bilgi sunmamıştı. ${ }^{225}$ Hatta bu âyetlerin tefsirinde verdiği bilgi tamamıla Ebu'l-Leys es-Semerkandî’nin tefsirinin ilgili kısmından alın-

221 Bk. Aydınî, Mecma 'u'l-Envar, 12: 250b.

222 Bk. Aydınî, Mecma'u'l-Envar, 12: 278b-281a.

223 Bk. Aydınî, Mecma'u'l-Envar, 12: 118a.

224 Bk. Aydınî, Mecma 'u'l-Envar, 12: 118a; er-Râzî, Mefâtîhu'l-Gayb, 30: 234.

225 Bk. Aydınî, Mecma'u'l-Envar, 12: 182a. Ayrıca bk. er-Râzî, Mefâtîhu'l-Gayb, 31: 129-131. 
madir. ${ }^{226}$ Sadece (فليتدبر بعقله ولينظر بقلبه هذا الانسان المكذب بالبعث مح خلق اب مماذا خلق) cümlesini Ebû Hafs Nesefî’ den alarak ${ }^{227}$ ilave etmiştir. Semerkandî bu âyetlerin yorumunda tıp alanıyla ilgili şu noktaya değinmiştir: İnsan annenin rahmine akıtılan bir sudan yaratılmıştır. Yani aslında insan iki sudan yaratılmıştır; babanın sulbünden gelen su ile annenin gögüs kemiklerinden gelen sudan... ${ }^{228}$

Baktığımız diğer bazı âyetlerde de tabip olmayan diğger müfessirlerin tefsirlerinde bulunanlardan farklı bir bilgi verdiğine şâhit olmadık. Görebildiğimiz kadarıyla burada verdiğimiz âyetlerin tefsirinde Ebû Hafs Nesefî̀ ve Râzî, Aydınî'den daha fazla embriyolojik bilgiler vermektedirler. Tabii ki bu konuda kesin bir karar vermek için Aydınî'nin eserinin hâlen kayıp olan ciltlerini, bilhassa Hac ve Mü'minûn sûrelerinin baş kısımlarını görmek gerekir. Şayet tefsirin her tarafinda böyle bir davranış sergilemiş ise o takdirde müellif ciddî bir tenkidi hak etmektedir. $^{229}$

\section{Sonuç}

Hacı Paşa Aydınî'nin Mecma'u'l-envâr isimli bu tefsiri, bir Osmanlı âlimi tarafından erken dönemlerde meydana getirilmiş olması açısından bizim için önemlidir. Ancak büyük oranda Ebû Hafs Nesefî ve Râzî’nin tefsirine bağlı kalması, onların ibare ve ifadelerini aynen tekrar etmesi onu, özgün bir tefsir olmaktan çıkarıp başkalarındaki bilgileri nakleden bir eser haline getirmektedir. Zaman zaman bu tefsirlerde bulunandan farklı bir şeyler söylemişse de bunlar çok azdır. Bu hâliyle eser, özgün ve orijinal bir eser görüntüsü vermekten uzaktır. Eserde Ebû Hafs Nesefî ve Râzî'den yapılan alıntılar çoğunlukla aynen verilirken, bazen ufak-tefek kelime farklılıkları görülmektedir. Yine sıklıkla buralarda bulunan bazı cümlelerin atlandığı, bunlara hiç yer verilmediği veya özetle verildiği müşahede edilmektedir. Eserin son cildi olan on ikinci ciltte Ebu'l-Leys es-Semerkandî’nin etkisi de sıklıkla görülmektedir. İyi bir eğitim almış ve farklı ilim dallarında pay sahibi bir âlim olan Aydınî'nin bu eserlerin etkisinde kalması ve onların ötesinde bir ufuk ortaya koymaması elbette dikkat çeken bir husustur. Arapçaya vâkıf tecrübeli bir Osmanlı âliminden bundan daha fazlası beklenirdi.

Burada şu hususa dikkat çekmek istiyoruz: Aynı dönem âlimi olan Kutbuddin İznikî’ye ait olan Tefsiru Kutbuddin adlı eser de tıpkı Hacı Paşa’nınki gibi büyük oranda Râzî’nin tefsiri esas alınarak oluşturulmuştur. Nitekim Râzî tefsiriyle yap-

226 Bk. es-Semerkandî, Tefsiru's-Semerkandî, 3: 467-468.

227 Bk. en-Nesefî, et-Teysîr fi 't-Tefsîr, 15: 298.

228 es-Semerkandî, Tefsiru's-Semerkandî, 3: 467-468.

229 Abay, “Osmanlı Dönemi Müfessirleri”, s. 25. 
tığımız kısmî karşılaştırmada bunu tespit ettik. Aynı dönemin ve aynı coğrafyanın âlimleri olan bu iki zatın aynı zamanda birer tefsir yazması takdire şayan olmakla birlikte, ikisinin de büyük oranda Râzî’nin tefsirinin etkisinde kalmaları odukça câlib-i dikkat bir husustur. Bunu, Râzî tefsirinin erken dönem Osmanlı âlimleri üzerindeki etkisiyle açıklamak mümkündür. Ayrıca bu husus, Osmanlı âlimlerinin geniş, ihatalı ve hacimli bir tefsire ihtiyaç duyduklarını ve bu ihtiyacı Ebû Hafs Nesefî̀ ve Râzî tefsiri üzerinden gidermeye çalıştıklarını da göstermektedir. Râzî’nin tefsiri daha sonraki dönemlerde de bazı Osmanlı âlimleri üzerinde etkili olmaya devam edecektir. Özellikle on dokuzuncu asırda yaşayan Giritli Sırrı Paşa'nın (v. 1895), Râzî tefsirinin Fâtiha sûresini kapsayan ilk cildini Türkçeye tercüme etmesi ve yine Râzî tefsirini esas alarak yapmış olduğu bazı sûre tefsirlerinde, yine aynı asrın bir âlimi olan Muallim Nâci'nin (v. 1893) Râzî tefsinden İhlâs sûresini Türkçeye aktarmasında bunu açık bir şekilde görmek mükündür. Râzî'nin tefsinin tamamı 1988-1995 yılları arasında Suat Yıldırım-Lütfullah Cebeci-Sadık Kılıç ve Sadık Doğru tarafından Türkçeye tercüme edilmiş ve Akça Yayınları tarafından 23 cilt olarak basılmıştır. Buna karşılık Ebû Hafs Nesefî'nin tefsirinin Osmanlılar döneminde kısmen veya tamamen tercüme edildiğine dair bir bilgiye rastamadık. Cumhuriyet'in ilanından bugüne kadarki yaklaşık yüz yıllık dönemde Teysîr üzerinde bazı tez ve tahkik çalışmaları yapıldığı halde tercüme edilmemiş idi. Ancak son zamanlarda Muhammed Coşkun tarafından hazırlanan bir proje kapsamında çevirisi yapılamkta ve Türkiye Yazma Eserler Kurumu Başkanlığı tarafından basılmaktadır. Eserin Muhammed Coşkun tarafından tercüme edilen birinci cildi, 2019, Ali Benli tarafından tercüme edilen ikinci cildi ise 2020 yılında tab' edilmiştir. Şu ana kadar Fatiha, Bakara ve Al-i İmrân suresinin 92. âyetine kadarki kısımları basılmış, geri kalan kısımlar da peyderpey basılacaktır. Bu eserlerin Türkçeye tercüme edilmiş olması, aynı zamanda -en azından eldeki mevcut ciltlere bakarak- Hacı Paşa Aydınî’nin tefsirinin de Türkçeye tercüme edilmiş olması demektir.

Aydınî’nin tefsiri, Ebû Hafs Nesefî̀ ve Râzî tefsirlerini esas alması itibariyle bir dirâyet tefsiridir. Tefsirde, etkisinde kaldığı tefsirlerdeki kadar rivâyetler de vardır. Esasen her dirâyet tefsirinde az veya çok rivâyet de vardır. Bununla birlikte bazen yukarıda belirttiğimiz bazı sûfî tefsirlerden alıntılar yaparak işârî yorumlar yaptığı da bir hakîkattir. Hatta her âyetin veya âyet gurubunun ardından -Tawfikî’nin başlıklandırmasında görüldüğü üzere- bu tür izahlar yapmaya yeltendiği müşahede edilmektedir.

Normalde “Anadolu'nun İbn Sînâ'sı" denecek kadar tıp alanında önemli bir âlim olması hasebiyle tıp alanıyla ilgili âyetleri daha geniş ve orijinal ifadelerle 
tefsir etmesi beklenirdi ancak müellif hiç de böyle davranmamıştır. Bu tür yerlerde dahi Semerkandî, Ebû Hafs Nesefî, Râzî tefsirlerinden istifade etmiş, eserine kendisi çok fazla yeni bir yorum katmamıştır. Bu açıdan da müfessiri eleştirmek mümkündür.

Muhtemelen bu hususiyetleri sebebiyle olsa gerek tefsir, ulemâ nezdinde pek itibar görmemiştir. Ulemânın ilgisiziliğini fazla istinsah edilmemiş olmasından anlayabiliyoruz. Bundan dolay1 -bugünkü bilgilerimize göre- bir bütün olarak günümüze ulaşmamıştır. Kütüphanelerimizde iki cildinin mevcudiyetine işaret edildiğini belirtmiştik. Ancak biz eserin son cildi olan on ikinci cildi de tespit ettik. $\mathrm{Bu}$, diğer ciltlerin bulunabileceği hususunda bizi umutlandırmaktadır. Kütüphanelerimizde mahtût eserler arasında yapılacak iyi bir tahkikât ile diğer ciltlerin de bulunabileceğine inanıoruz.

İnceleyebildiğimiz ciltleri itibariyle kendinden önce yazılmış bazı tefsirlerden yapılan alıntılara dayanan bir tefsir olsa da Osmanlı'nın erken dönemlerinde bir Osmanlı âlimi tarafından vücuda getirilmiş olması bizim açımızdan önemlidir. Müellifin muhtelif tefsirlerden yaptığı alıntılatıları gayet uyumlu ve güzel bir şekilde birbiriyle mezc etmesi de onun bu alandaki yetkinliğini göstermesi açısından mühimdir.

Osmanlı tefsiri üzerinde daha fazla araştırma yapmak gerektiği ortadadır. Akademisyen ve araştımacıların dikkatlerini bu noktaya çekmek isteriz. Önemli bazı çalışmaların yapıldığının farkındayız, ancak bundan daha fazlasını yapmak gerekir. Osmanlı tefsirinin boyutları hakkında bir hüküm vermek için bunun yapılması bir zarurettir. Osmanlı âlimlerine ait olup yeni tespit edebildiğimiz eserler veya kayıp olduğu sanılan bazı ciltler bulunabildiği gibi, henüz bulunamamış tefsir eserleri yahut eksik ciltler de mevcuttur. Yapılacak çalışmalar bu noktada büyük hizmet arz edecektir. Biz bu çalışmayla Osmanlı tefsir kültürüne bir nebzecik de olsa katkı verebilmiş isek hedeflenen maksad hâsıl olmuş demektir. 


\section{Kaynakça}

Abay, Muhammed, “Osmanlı Dönemi Müfessirleri”, (Yayımlanmamış Yüksek Lisans Tezi), Uludağ Üniversitesi Sosyal Bilimler Enstitüsü Temel İslam Bilimleri Ana Bilim Dalı Tefsir Bilim Dalı, 1992.

Acıduman, Ahmet - İlgili, Öner, "Erken Dönem Türkçe Tıp Yazmalarından Hacı Paşa'nın (Celalüddin Hızır) Teshîl Adlı Eserinde Çocuk Sağlığı ve Hastalıkları Üzerine Bir Ön Çalışma”. Çocuk Sağllğ v ve Hastalıkları Dergisi, cilt 54, say1 4, 2011.

Adıvar, A. Adnan, Osmanlı Türklerinde İlim, İstanbul, Remzi Kitabevi, 1982.

Akpınar, Cemil, "Hacı Paşa", Türkiye Diyanet Vakfi İslam Ansiklopedisi (DIA), cilt 14, İstanbul, Türkiye Diyanet Vakfı Yayınları, 1996.

Algar, Hamid, "Bahrü'l-Hakâik ve'l-Meânî”, Türkiye Diyanet Vakfi İslam Ansiklopedisi, cilt 4, İstanbul, Türkiye Diyanet Vakfi Yayınları, 1991.

Aydınî, Hacı Paşa, Mecma 'u'l-Envârfì Cemî'i 'l-Esrâr, Carullah, 94: 1a-417b, Millet Genel Kütüphanesi.

, Mecma'u'l-Envâr fí Cemî'i'l-Esrâr, Kastamonu Kitaplığg1 (Kastamonu Yazma Eser Kütüphanesi), 3065, 12: 1a-283b, Milli Eğitim Bakanlığ1 (Yazma Eserler Kurumu Başkanlığı).

Dil Kurumu, 1990.

, Celâl Hızır, Müntehâb-ı Şifâ. haz. Zafer Önler, Ankara, Türk

Babur, Ahmet, "Hacı Paşa ve Mecma'u'l-Envâr fi Cemî'i'l-Esrâr Adlı Tefsirindeki Metodu", (Yayımlanmamış Yüksek Lisans Tezi), Necmettin Erbakan Üniversitesi Sosyal Bilimler Enstitüsü Temel İslam Bilimleri Ana Bilim Dalı Tefsir Bilim Dal1, 2016.

Buhârî, Ebû Abdillah Muhammed b. İsmail, Sahîhu'l-Buhârî : Mevsûatu'l-hadîsi'ş-şerîf el-kutubu's-sitte, nşr. Salih b. Abdulaziz b. Muhammed b. İbrahim Ali'ş-Şeyh, er-Riyâd, Dâru's-Selâm li'n-Neşri ve't-Tevzî', 1419.

Bursal1, Mehmed Tahir Bey, Osmanlı Müellifleri. haz. İsmail Özen, İstanbul, Meral Yayınevi, 1975.

Bursevî, İsmail Hakkı, Rûhu'l-Beyân, İstanbul, Matbaatu'l-Osmaniyye, 1330.

Cezar, Mustafa, Mufassal Osmanl Tarihi Resimli-Haritall, Ankara, Türk Tarih Kurumu, 2010.

Çelebi, İlyas, "Vefk" Türkiye Diyanet Vakfi İslam Ansiklopedisi, cilt 42, İstanbul, Türkiye Diyanet Vakfi Yayınları, 2012. 
Danişmend, İsmail Hâmî, İzahlı Osmanlı Tarihi Kronolojisi, İstanbul, Türkiye Yayınevi, 1971.

Demir, Ziya, XIII-XVI. Yüzyıl Arası Osmanlı Müfessirleri, İstanbul, Ensar Neşriyat, 2007.

Demiralp, Yekta, "Erken Dönem Osmanlı Medreseleri”, (Yayımlanmamış Doktora Tezi), Ege Üniversitesi Sosyal Bilimler Enstitüsü Arkeoloji ve Sanat Tarihi Ana Bilim Dalı, 1997.

Ebu's-Suûd, b. Muhammed el-İmâdî el-Hanefî, Tefsiru Ebî's-Suûd ev İş̧âdu Akli 's-Selîm ilâ Mezâya'l-Kitâbi'l-Kerîm, thk. Abdulkadir Ahmed Atâ, er-Riyâd, Mektebetu'r-Riyâd el-Hadîse, ts.

Güney, Ahmet Faruk, “Gaza Devrinde Kur'ân'1 Yorumlamak: Fetih Öncesi Osmanlı Müfessirleri ve Tefsirleri”. Dîvân İlmî Araştırmalar, sayı 18, 2005/1.

Hizlı, Mefail, "Osmanlı Medreselerinde Okutulan Dersler ve Eserler", Uludă̆ Üniversitesi Illahiyat Fakültesi Dergisi, cilt 17, sayı 1, 2008.

Hübeyş̂, Cemâluddin Muhammed, b. Abdurrahman Ibn Ömer, Neşru Tayyi 't-Ta 'rîffí Fadli Hameleti'l-İlmi'ş̧-Şerîf, Cidde, Dâru'l-Minhac, 1997.

İbn Mâce, Ebû Abdillah Muhammed b. Yezid, Sünenu İbn Mâce el-Kazvîn : el-Kutub es-Sitte Mevsûatu'l-Hadîs eş-Şerîf, nşr. Salih b. Abdulaziz b. Muhammed b. İbrahim Alu'ş-Şeyh, er-Riyâd, Dâru's-Selâm li'n-Neşri ve't-Tevzî’, 1419 .

İpşirli, Mehmet, "Medrese (Osmanlı Dönemi)", Türkiye Diyanet Vakfı İslam Ansiklopedisi. cilt 28, İstanbul, Türkiye Diyanet Vakfı Yayınları, 2003.

Kahya, Ersin, "Konyalı Bir Hekim, Hacı Paşa", Türk-İslam Medeniyeti Akademik Araştırmalar Dergisi (Konya Özel Sayısı), sayı 5, 2008.

Kahya, Esin, "Hacı Paşa”, Ankara Üniversitesi Osmanlı Araştırmaları Merkezi (OTAM), sayı 3, 1992.

Kâtip Çelebî, Mustafa b. Abdullah Hacı Halife, Keşfu'z-Zunûn an Esâmi'l-Kutubi ve'l-Fünûn, Beyrût, Dâru İhyâi't-Turâsi'l-Arabî, ts.

Kuşeyrî, Ebu'l-Kasım Abdülkerim b. Hevâzin, Tefsîru'l-Kuşerî el-Musemmâ Letâifu' 'l-İşârât, nşr. Abdullatif Hasan Abdurrahman, Beyrût, Dâru'l-Kutubi'l-ìlmiyye, 1428/2007.

Kübrâ, Ahmed b. Ömer Necmuddin, et-Te'vîlâtu'n-Necmiyye fi't-Tefsîri'l-İ̧̧ârî es-Sûfí, thk. Ahmed Ferdi el-Mezyudî, Beyrût, Dâru'l-Kutubi'l-İlmiyye, 2009. 
Mecdî Efendî, Edirneli, Şekâik-i Nu'mâniye Tercemesi, İstanbul, Tabhane-i Amire, 1369.

Nesefî, Ebû Hafs Necmuddîn b. Ömer b. Muhammed, et-Teysîrfi't-Tefsîr, thk. Mahir Edib Habbûş, İstanbul, Dâru'l-Lübâb, 1440/2019. tu'l-Melik Suûd. , et-Teysîr fi't-Tefsîr, Kısmu'l-Mahtûtât, 4923, 1: 1a-67a. Câmia, et-Teysîr fìt-Tefsîr. 87713, 1: 1a-251.b. (İran) Kütüphâne-i Şûrây-i Meclis-i Millî.

, et-Teysîr fi't-Tefsîr Ömer Nesefì Tefsiri, çev. Muhammed Coşkun, İstanbul, Türkiye Yazma Eserler Başkanlığı Yayınları, 2019.

Okka, Berrin, "Tıp Tarihinde Mumyalama İşlemi, Konyalı Hekim Hacı Paşa ve Tahnit", Uluslararası Islam Medeniyetinde Zaman Sempozyumu, ed. Bilal Kuşpınar, 08-11 Ekim2015/Konya, İstanbul, Bilir Matbaacılık, 2016.

Önler, Zafer, "XIV-XV. Yüzyıl Türkçe Tıp Metinlerinin Dili ve Sözvarlığı”, Kebikeç, sayı 6, 1998.

, "Celâleddin Hızır (Hacı Paşa) Müntahab-1 Şifa İnceleme-Metin-Dizinler”, (Yayımlanmamış Doktora Tezi), Fırat Üniversitesi Sosyal Bilimler Enstitüsü Türk Dili ve Edebiyatı Ana Bilim Dalı, Elazığ, 1981.

, "Eski Anadolu Türkçesi Döneminde Yazılmış İki Tıp Kitabında Yer Alan Sağlık Bilgisi Terimleri”, Türk Dil Araştırmaları Yıllı̆̆ı (TDAY) Belleten, cilt 33, 1985.

Öztürk, Mustafa, "Klasik ve Modern Dönem Osmanlı Medrese Geleneğinde Tefsir Tedrisatı", Medrese Geleneği ve Modernleşme Sürecinde Medreseler Uluslararası Sempozyum, 5-7 Ekim 2012 Muş, Muş, Alparslan Üniversitesi Yayınları, 2013.

, "Osmanlı Tefsir Kültürüne Panoramik Bir Bakış”, Osmanl Toplumunda Kur'ân Kültürü ve Tefsir Çalışmaları I, (içinde), ed. Bilal Gökkır - Necdet Yılmaz - Necmettin Gökkır - Ömer Kara - Muhammed Abay - Mustafa Karagöz, İstanbul, İlim Yayma Vakfı Yayınları, 2011.

Paçac1, Mehmet, "Osmanlı Medreselerinde Tefsir Öğretiminin Yeri ve Tefsirin Çağdaşlıkla Karşılaşması”, Osmanlı Toplumunda Kur'an Kültürü ve Tefsir Çalışmaları I, (içinde), ed. Bilal Gökkır - Necdet Yılmaz - Necmettin Gökkır Ömer Kara - Muhammed Abay - Mustafa Karagöz, İstanbul, İlim Yayma Vakfı Yayınlar1, 2011. 
Râzî, Fahreddin, Tefsîr-i Kebîr Mefâtîhu'l-Gayb, trc. Suat Yıldırım - Lütfullah Cebeci - Sadık Kılıç - Sadık Doğru, İstanbul, Huzur Yayınevi, ts.

Râzî, Fahruddin, Tefsîru'l-Fahr er-Râzî et-Tefsîru'l-Kebîr Mefâtîhu'l-Gayb, Beyrût, Dâru'l-Fikr, 1401/1981.

Rıza, Adnan A., “Hacı Paşa'nın Kitab-1 Şifau'l-Eskam ve Devaül-Alam Adlı Eseri Üzerinde İnceleme”, (Yayımlanmamış Yüksek Lisans Tezi), Ankara Üniversitesi Sağlık Bilimleri Enstitüsü, Farmasötik Teknoloji Ana Bilim Dalı, Farmasötik Teknoloji Bilim Dalı, 1987.

Semerkandî, Ebu'l-Leys Nasr b. Muhammed, Tefsiru's-Semerkandî el-Musemma Bahru'l-U'lûm,

thk. Ali Muhammed Muavvid - Adil Ahmed Abdulmevcûd - Zekeriya Abdulmecid en-Nûtî, Beyrût, Dâru'l-

Kutubi'l-İlmiyye, 1413/1993.

Şar, Sevgi - Sözen, Bilge Şabne - Arslan, Miray, “Hacı Paşa'nın Şifâü'l Eskâm ve Devâü'l-Âlâm Adl1

Eserindeki Şurup Formülleri”, Ankara Üniversitesi Osmanlı Araştırmaları Merkezi (OTAM), say1 35, 2014.

Şentürk, Fatma, “Aydınoğulları Beyliğinde Edebî ve Kültürel Hayat”, (Yayımlanmamış Yüksek Lisans Tezi), Osmangazi Üniversitesi Sosyal Bilimler Enstitüsü Türk Dili ve Edebiyatı Ana Bilim Dalı Eski Türk Edebiyatı Bilim Dalı, 2014.

Taşköprizâde, Ahmed Efendi, eş-Şekâiku'n-Nu'mâniyye fí Ulemâi'd-Devleti'l-Osmâniyye, Beyrût, Dâru'l-Kutubi'l-İlmiyye, ts.

, Osmanlı Bilginleri eş-Şekâiku'n-Nu'mâniyye fí Ulemâi'd-Devleti'l-Osmâniyye, trc. Muharrem Tan, İstanbul, İz Yayınc1lı, 2007.

Tawfik, Ahmed Mahmoud Zakaria, "Hâcî Paşa el-Konevî ve Tefsîruhu Mecma'u'l-Envâr fî̀ Cemî'i'l-Esrâr el-Mucelledu'l-Evvel Dirâse ve Tahkîk", (Yayımlanmamış Doktora Tezi), Necmettin Erbakan Üniversitesi Sosyal Bilimler Enstitüsü Temel İslam Bilimleri Ana Bilim Dalı Tefsir Bilim Dalı, 2020.

Turan, Zikri, "Hacı Paşa (Celaleddin Hızır) Teshil, Dil Özellikleri Metin (1. Cilt)", (Yayımlanmamış Doktora Tezi), İnönü Üniversitesi Sosyal Bilimler Enstitüsü, Türk Dili ve Edebiyatı Ana Bilim Dalı, 1992.

Uludağ, Süleyman, "Kâşânî, Abdürrezzâk", Türkiye Diyanet Vakfi İslam Ansiklopedisi, cilt 25, İstanbul, Türkiye Diyanet Vakfı Yayınları, 2002. 
Ünver, Ahmet Süheyl, Hekim Konyalı Hacı Paşa, İstanbul, İstanbul Üniversitesi, 1953.

Üstün, Çağatay, “Hekim Haci Pasa's (Physician Hadji Pasha) Brief Bioraphy and his Opinions on Medical Deontology". S.D.Ü. Tip Fakültesi Dergisi, cilt 17, sayı 1, 2010.

Veyestî, el-Hüseyin b. Yahya ez-Zende el-Hanefî, Ravdatu'l-Ulemâ ve Nüzhetu'l-Fudalâ, thk. Beşir Berman, Beyrût, Dâru'l-Kutubi'l-İlmiyye, 2020.

Yıldız, Sakıp, “Osmanlı Tefsir Hareketine Toplu Bakış”, Uludağ Üniversitesi Ilahiyat Fakültesi Dergisi, cilt 2, say1 1, 1987.

\section{Araştırmacıların Katkı Oranı}

Araştırmanın her aşamasından yazar sorumludur.

\section{Çatışma Beyanı}

Araştırmada herhangi bir çıkar çatışması bulunmamaktadır. 